PERFORMANCE ANALYSIS OF DRILLING FLUID LIQUID LUBRICANTS

A THESIS SUBMITTED TO

THE GRADUATE SCHOOL OF NATURAL AND APPLIED SCIENCES $\mathrm{OF}$ MIDDLE EAST TECHNICAL UNIVERSITY

BY

AHMET SÖNMEZ

IN PARTIAL FULFILLMENT OF THE REQUIREMENTS

FOR

THE DEGREE MASTER OF SCIENCE

IN

PETROLEUM AND NATURAL GAS ENGINEERING

SEPTEMBER 2011 
Approval of the thesis:

\section{PERFORMANCE ANALYSIS OF DRILLING FLUID LIQUID LUBRICANTS}

submitted by AHMET SÖNMEZ in partial fulfillment of the requirements for the degree of Master of Science in Petroleum and Natural Gas Engineering Department, Middle East Technical University by,

Prof. Dr. Canan Özgen

Dean, Graduate School of Natural and Applied Sciences

Prof. Dr. Mahmut Parlaktuna

Head of Department, Petroleum and Natural Gas Engineering

Prof. Dr. Mustafa Verşan Kök

Supervisor, Petroleum and Natural Gas Engineering Dept., METU

\section{Examining Committee Members}

Prof. Dr. Mahmut Parlaktuna

Petroleum and Natural Gas Engineering Dept., METU

Prof. Dr. Mustafa Verşan Kök

Petroleum and Natural Gas Engineering Dept., METU

Prof. Dr. Nurkan Karahanoğlu

Geological Engineering Dept., METU

Dr. Reha Özel

TPAO Research Center, ANKARA

Dr. A.Gürkan İşcan

Çalık Enerji, ANKARA

Date: $13 / 09 / 2011$ 
I hereby declare that all information in this document has been obtained and presented in accordance with academic rules and ethical conduct. I also declare that, as required by these rules and conduct, I have fully cited and referenced all material and results that are not original to this work.

Name, Last name $\quad$ : Ahmet SÖNMEZ

Signature 


\begin{abstract}
PERFORMANCE ANALYSIS OF DRILLING FLUID LIQUID LUBRICANTS

\author{
Sönmez, Ahmet \\ M.Sc., Department of Petroleum and Natural Gas Engineering \\ Supervisor: Prof. Dr. Mustafa Verşan Kök
}

September 2011, 95 pages

Excessive torque is one of the most important problems in oil/gas drilling industry. Friction between wellbore/casing and drill string causes excessive torque. This study discusses performance analysis of drilling fluid lubricants, which are used as friction reducers in well-bore. Three different types of commercial chemical lubricants, which are fatty acid and glycerid based, triglycerid and vegetable oil based and polypropylene glycol based, diesel oil, and crude oil, which consists of different API gravity, paraffin and asphaltene value samples, were selected for the analysis.

In the analysis, different lubricant compositions with the mixture of commercial chemical lubricants, crude oil and diesel oil, which were added to water based lignosulfonate mud, are tested on metal-metal contact surface by Ofite Lubricity Tester to determine the best lubricity/cost ratio of lubricant compositions. 
Moreover, effects of the lubricants on mud rheology and API fluid loss of mud, foam forming potential and cheesing/greasing of the lubricants and the influence of mud properties on lubricants (calcium, salt, $\mathrm{pH}$ and mud density) are examined.

Keywords: drilling fluid, mud, lubricant, lubricity, lubricity coefficient 


\title{
ÖZ
}

\section{SONDAJ SIVISINA EKLENEN SIVI KAYGANLAŞTIRICILARIN PERFORMANS ANALİŻ}

\author{
Sönmez, Ahmet \\ Yüksek Lisans, Petrol ve Doğal Gaz Mühendisliği Bölümü \\ Tez Yöneticisi: Prof. Dr. Mustafa Verşan Kök
}

Eylül 2011, 95 sayfa

\begin{abstract}
Aşırı tork değerleri, petrol ve doğalgaz sondaj endüstrisindeki en önemli problemlerden biridir. Sondaj dizisi ve kuyu cidarı veya koruma borusu arasındaki sürtünmeler aşırı torka yol açmaktadır. Bu çalışmada, sondaj operasyonları sırasında, kuyu içinde oluşan sürtünmeleri azaltmak için sondaj sıvısına eklenen sıvı kayganlaştırıcıların performans analizi ve değerlendirmesi yapılmıştır. Analizler için, kayganlaştırıcı olarak; yağ asidi ve gliserid bazlı, trigliserid ve nebati yağ bazlı, ve polipropilen glikol bazlı üç çeşit ticari kimyasal lubrikant, mazot ve değişik API yoğunluk, asfaltit ve parafin değerlerine sahip ham petrol numuneleri seçilmiştir.
\end{abstract}

$\mathrm{Su}$ bazlı lignosülfonat sondaj sıvılarına, kayganlaştırıcılar değişik oranlarda karıştırılarak, Ofite Lubricity Tester cihazında, metal-metal temas yüzeylerinde oluşan tork değerleri için en iyi performansı veren kompozisyonların belirlenmesi hedeflenmiştir. 
Ayrıca, bu kayganlaştırıcıların, diğer sondaj sıvısı özelliklerine etkileri (akış özellikleri, su kayb1, köpük oluşma potansiyeli ve peynirsi tabaka oluşumu/yüzeyde yağlanma) ile; sondaj sıvısının özelliklerindeki (kalsiyum, tuz, pH ve çamur yoğunluğu) değişimin, kayganlaştırıcıların performanslarına olan etkileri incelenmiştir.

Anahtar Sözcükler: sondaj sıvısı, çamur, lubrikant, kayganlık, kayganlık katsayısı. 
to my family... 


\section{ACKNOWLEDGMENTS}

I wish to express my deepest gratitude to my supervisor Prof. Dr. Mustafa Verşan KÖK and my manager Dr. Reha ÖZEL for their guidance, advice, criticism and encouragements throughout the research.

Also, Mehmet ÇELIK and Hüseyin Ali DOĞAN of Turkish Petroleum Corporation are gratefully acknowledged of their help and assistance.

The technical assistance of Engin Özgür ÖZMEN is gratefully acknowledged.

I would also like to thank my whole family and friends especially Ufuk GEZEN, Gökçe GÜVEN, Satı Aslı GÜNDOĞAR and Tuğçe BAYRAM for their endless patience and invaluable support throughout the study. 


\section{TABLE OF CONTENTS}

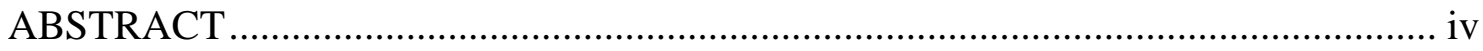

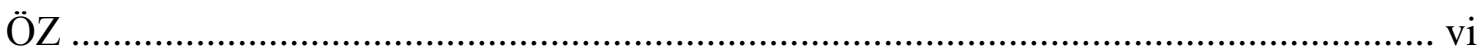

ACKNOWLEDGMENTS _................................................................................. ix

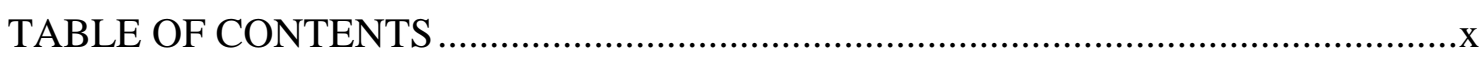

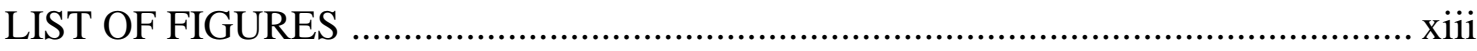

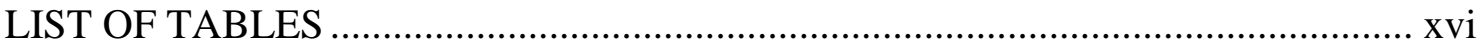

CHAPTERS

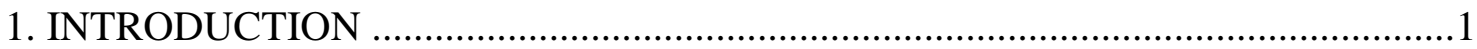

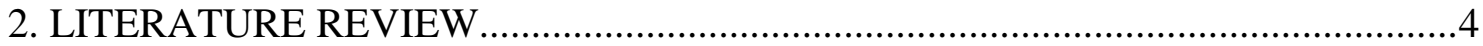

2.1. Overview of Lubricity Analysis .................................................................4

2.2. Effects of Lubricants on Mud Properties ........................................................ 12

2.3. Influence of Mud Properties on Lubricity...................................................... 14

3. STATEMENT OF THE PROBLEM …............................................................ 18

4. EXPERIMENTAL SET-UP AND PROCEDURE .............................................. 19

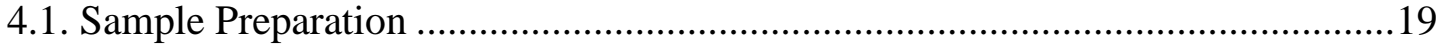

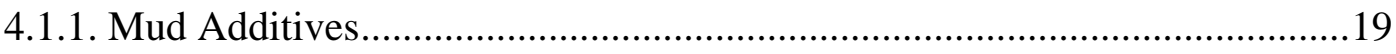

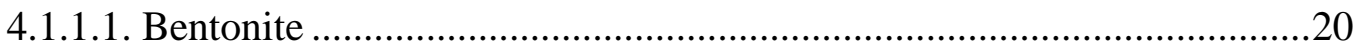

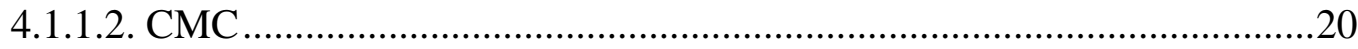

4.1.1.3. Chrome Free Lignosulfonate (CFL) ..............................................20

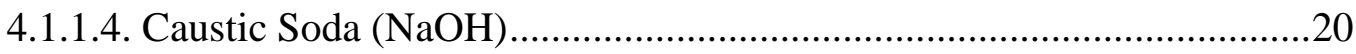

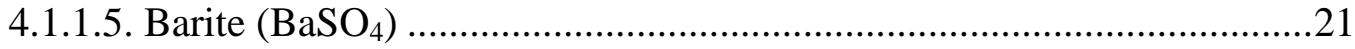

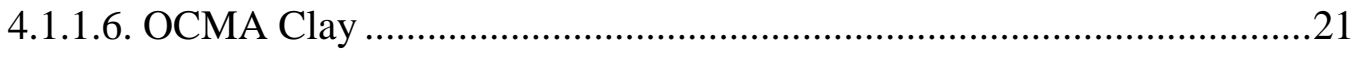

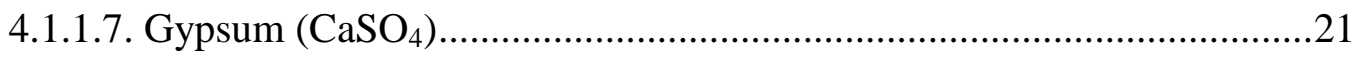

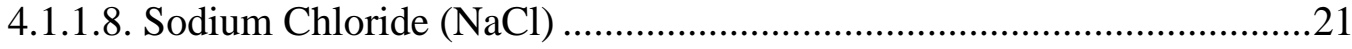

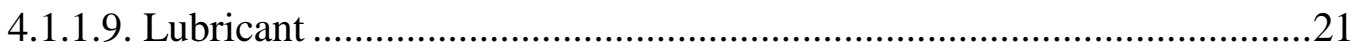

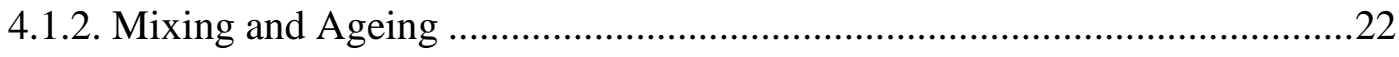




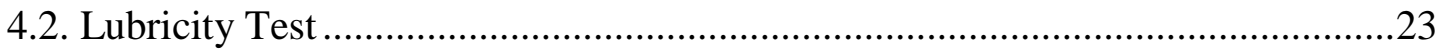

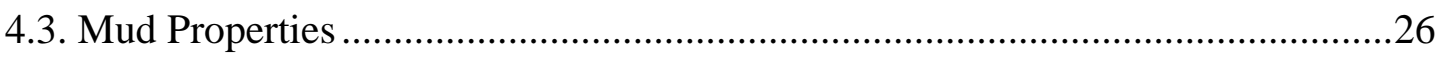

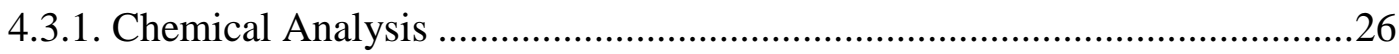

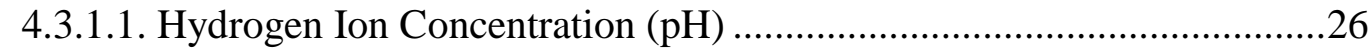

4.3.1.2. Determining Chloride Ion Content.........................................................27

4.3.1.3. Determining Calcium Ion Content ........................................................28

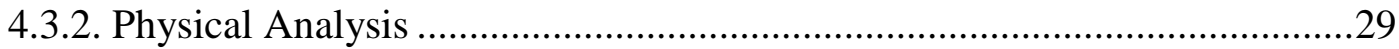

4.3.2.1. Density Measurement (Mud Weight)......................................................29

4.3.2.2. Rheological Analysis ............................................................................. 31

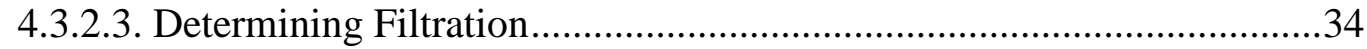

4.3.2.4. Determining Foam Forming Potential ......................................................35

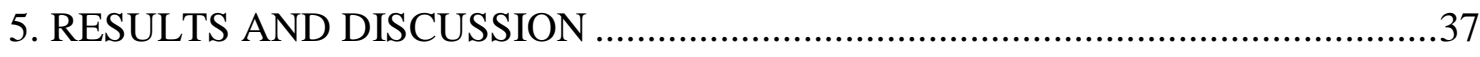

5.1. Lubricity Performance Analysis ...........................................................................

5.1.1. Lubricity Performance Analysis of Lubricants Added to the Water-Based

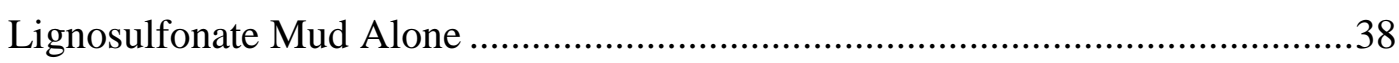

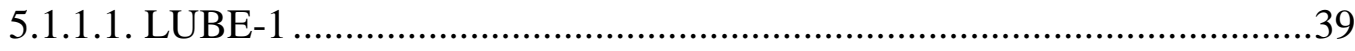

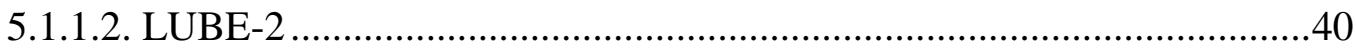

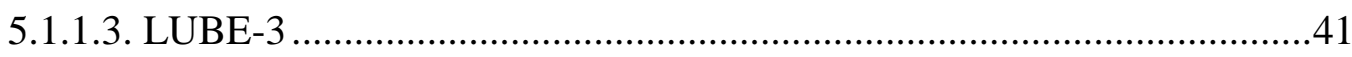

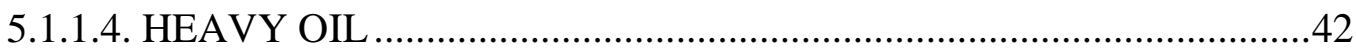

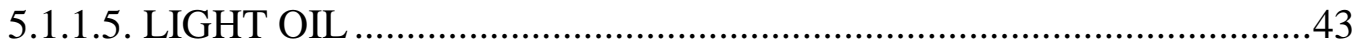

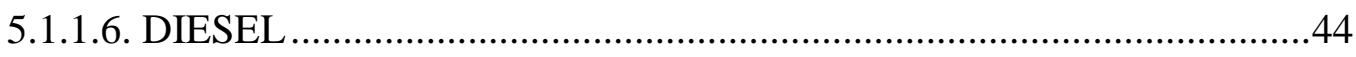

5.1.2. Lubricity Performance Analysis of LUBE-1, LUBE-2 AND LUBE-3 Mixed with HEAVY OIL, LIGHT OIL and DIESEL, Added to the Water-Based

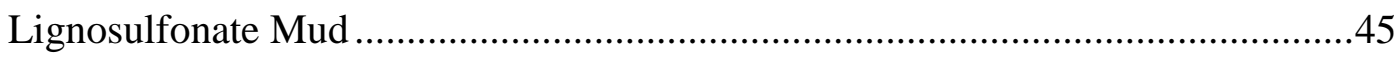

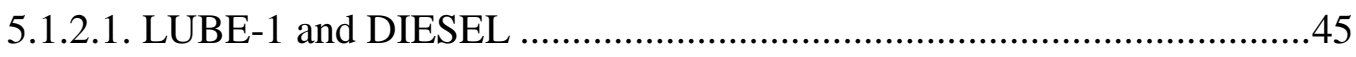

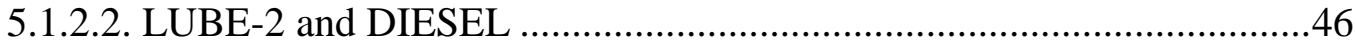

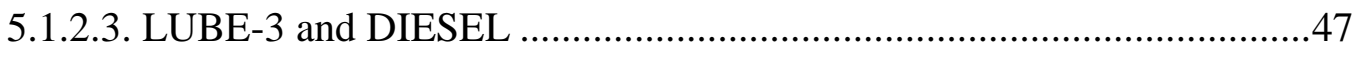

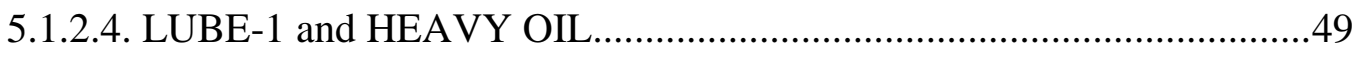

5.1.2.5. LUBE-2 and HEAVY OIL................................................................50

5.1.2.6. LUBE-3 and HEAVY OIL................................................................ 


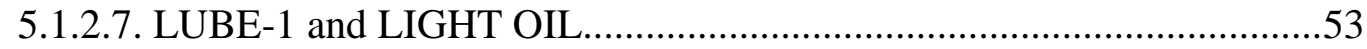

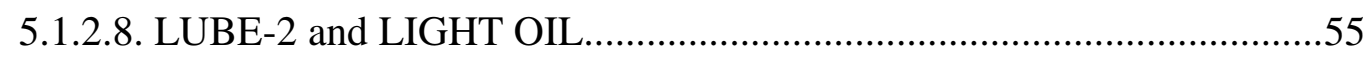

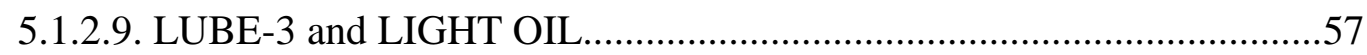

5.2. Analysis of Lubricants Effects on Mud Properties .............................................61

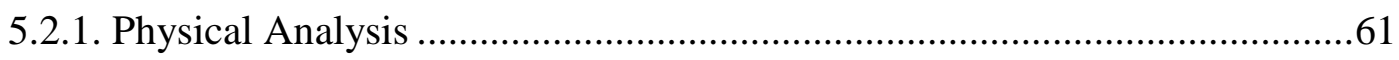

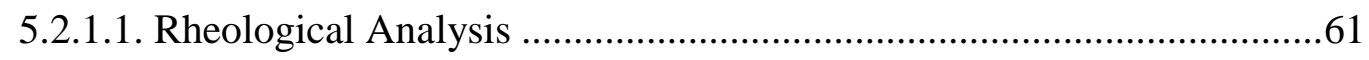

5.2.1.2. Fluid Loss Analysis.............................................................................64

5.2.1.3. Cheesing/Greasing Analysis ...............................................................65

5.2.1.4. Foam Forming Potential Analysis............................................................66

5.2.2. Chemical Analysis ..................................................................................67

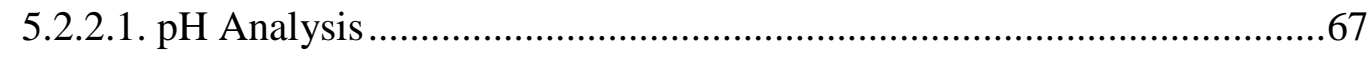

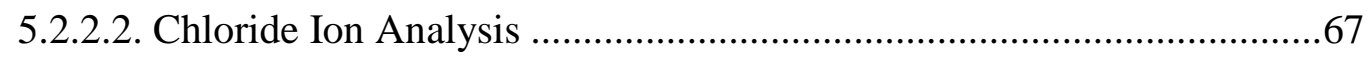

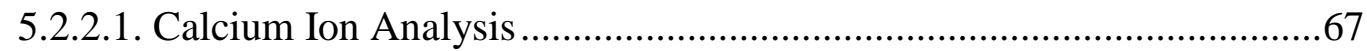

5.3. Analysis of Influence of Mud Properties on Lubricity ...........................................67

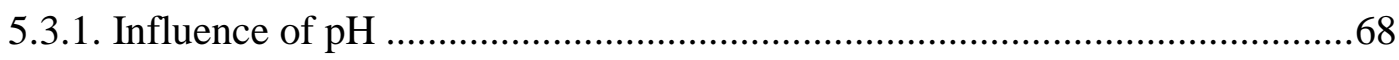

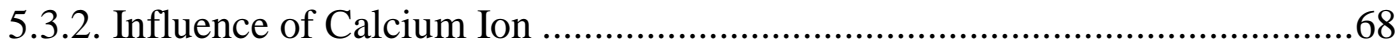

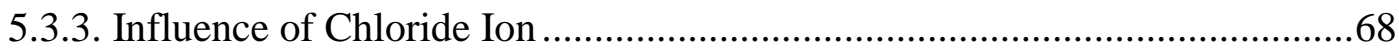

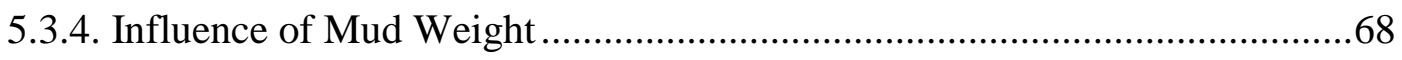

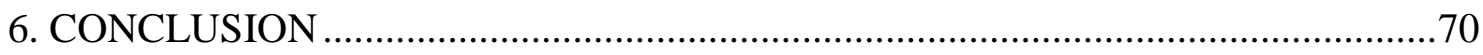

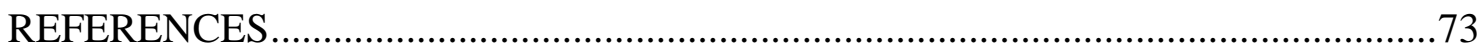

APPENDICES

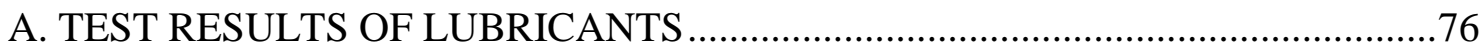




\section{LIST OF FIGURES}

\section{FIGURES}

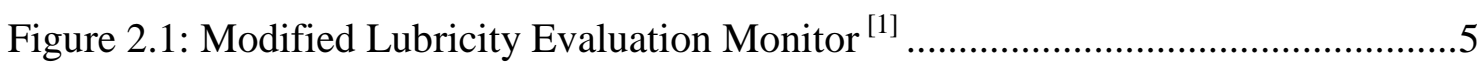

Figure 2.2: WBFS Overall View ${ }^{[1]}$.................................................................

Figure 2.3: LEM III Lubricity Test Unit ${ }^{[4]}$........................................................ 8

Figure 2.4: Differential Pressure Sticking and Friction Measurement Cell ${ }^{[6]}{ }^{6 . . . . . . . . . . . . . . . . . ~} 9$

Figure 2.5: Schematic Diagram of the Stickance Tester ${ }^{[7]}$........................................ 10

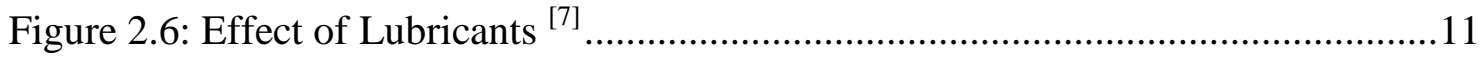

Figure 2.7: A 10\% Aqueous Dispersion of Starch-Lubricant ${ }^{[9]}$.................................... 12

Figure 2.8: Effect of Adding Bentonite to Distilled Water ${ }^{[12]}$..................................... 16

Figure 2.9: Effect of Adding Barite to an Unweighted Water Based Drilling Fluid ${ }^{[12]} .17$

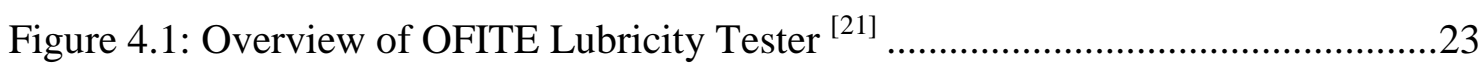

Figure 4.2: Placing Lubricity Test Block in the Block Holder ${ }^{[21]}$...............................24

Figure 4.3: Overview of OFITE Metal Mud Balance ${ }^{[25]}$.............................................30

Figure 4.4: Cross Section View of FANN Model 35 Viscometer ${ }^{[27]}$.............................32

Figure 4.5: Overview of OFITE Low Pressure Filter Press ${ }^{[28]}$.................................... 34

Figure 4.6: Overview of Chandler Model 7000 Constant Speed Mixer .........................36

Figure 5.1: Overall Analysis of Lubricants Added to the Water-Based Lignosulfonate

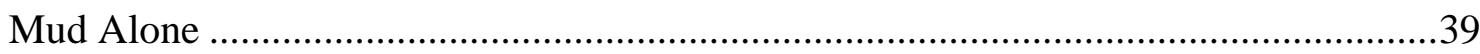

Figure 5.2: Coefficient of Frictions of LUBE-1 Added to the Water-Based

Lignosulfonate Mud

Figure 5.3: Coefficient of Frictions of LUBE-2 Added to the Water-Based

Lignosulfonate Mud

Figure 5.4: Coefficient of Frictions of LUBE-3 Added to the Water-Based

Lignosulfonate Mud 
Figure 5.5: Coefficient of Frictions of HEAVY OIL Added to the Water-Based Lignosulfonate Mud

Figure 5.6: Coefficient of Frictions of LIGHT OIL Added to the Water-Based

Lignosulfonate Mud .44

Figure 5.7: Coefficient of Frictions of DIESEL Added to the Water-Based

Lignosulfonate Mud .45

Figure 5.8: Coefficient of Frictions of 1\% LUBE-1, and 2\% DIESEL Mixed with 1\%

LUBE-1 and Added to the Water-Based Lignosulfonate Mud .46

Figure 5.9: Coefficient of Frictions of 1\% LUBE-2, and 2\% DIESEL Mixed with 1\%

LUBE-2 and Added to the Water-Based Lignosulfonate Mud .47

Figure 5.10: Coefficient of Frictions of 1\% LUBE-3, and 2\% DIESEL Mixed with 1\%

LUBE-3 and Added to the Water-Based Lignosulfonate Mud 48

Figure 5.11: Overall Analysis of 1\% LUBE-1, LUBE-2 and LUBE-3 mixed with

DIESEL and Added to the Water-Based Lignosulfonate Mud

Figure 5.12: Coefficient of Frictions of 1\% LUBE-1, and 2\% HEAVY OIL Mixed with

$1 \%$ LUBE-1 and Added to the Water-Based Lignosulfonate Mud .50

Figure 5.13: Coefficient of Frictions of 1\% LUBE-2, and 2\% HEAVY OIL Mixed with $1 \%$ LUBE-2 and Added to the Water-Based Lignosulfonate Mud .51 Figure 5.14: Coefficient of Frictions of 1\% LUBE-3, and 2\% HEAVY OIL Mixed with

1\% LUBE-3 and Added to the Water-Based Lignosulfonate Mud .52

Figure 5.15: Overall Analysis of 1\% LUBE-1, LUBE-2 and LUBE-3 mixed with HEAVY OIL and Added to the Water-Based Lignosulfonate Mud .53

Figure 5.16: Coefficient of Frictions of 1\% LUBE-1, and 1\%, 2\% and 3\% LIGHT OIL Mixed with 1\% LUBE-1 and Added to the Water-Based Lignosulfonate Mud.............54 Figure 5.17: Coefficient of Frictions of 2\% LUBE-1, and 1\%, 2\% and 3\% LIGHT OIL Mixed with 2\% LUBE-1 and Added to the Water-Based Lignosulfonate Mud .55 Figure 5.18: Coefficient of Frictions of 1\% LUBE-2, and 1\%, 2\% and 3\% LIGHT OIL Mixed with 1\% LUBE-2 and Added to the Water-Based Lignosulfonate Mud. .56 Figure 5.19: Coefficient of Frictions of 2\% LUBE-2, and 1\%, 2\% and 3\% LIGHT OIL Mixed with 2\% LUBE-2 and Added to the Water-Based Lignosulfonate Mud 
Figure 5.20: Coefficient of Frictions of 1\% LUBE-3, and 1\%, 2\% and 3\% LIGHT OIL Mixed with 1\% LUBE-3 and Added to the Water-Based Lignosulfonate Mud..............58 Figure 5.21: Coefficient of Frictions of 2\% LUBE-3, and 1\%, 2\% and 3\% LIGHT OIL Mixed with 2\% LUBE-3 and Added to the Water-Based Lignosulfonate Mud.............59 Figure 5.22: Overall Analysis of 1\% LUBE-1, LUBE-2 and LUBE-3 mixed with LIGHT OIL and Added to the Water-Based Lignosulfonate Mud .60

Figure 5.23: Overall Analysis of 2\% LUBE-1, LUBE-2 and LUBE-3 mixed with

LIGHT OIL and Added to the Water-Based Lignosulfonate Mud

Figure 5.24: Plastic Viscosity Values of Lubricants Added to the Water-Based

Lignosulfonate Mud .62

Figure 5.25: Yield Point Values of Lubricants Added to the Water-Based

Lignosulfonate Mud

Figure 5.26: API Fluid Loss of Lubricants Added to the Water-Based Lignosulfonate Mud .65

Figure 5.27: Example of a Curd-Like Phase on the Surface of Drilling Fluid .66 


\section{LIST OF TABLES}

\section{TABLES}

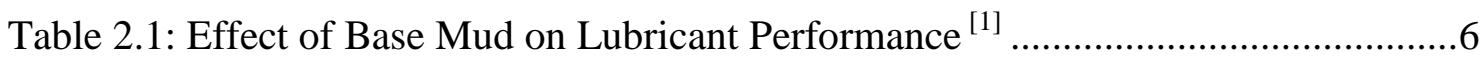

Table 2.2: Rheology, Fluid Loss Comparisons between Diesel and SSP ${ }^{[10]} \ldots \ldots \ldots \ldots \ldots . . . . . .13$

Table 2.3: Influence of Ester Based Lubricant on Rheological and Filtration Properties

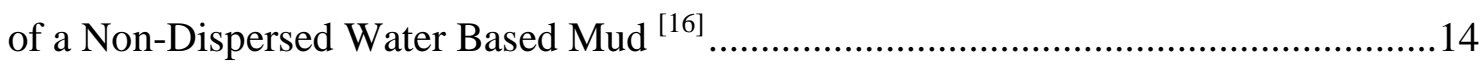

Table 2.4: Friction Coefficients with 1 vol\% Bead Concentration in an Unweighted

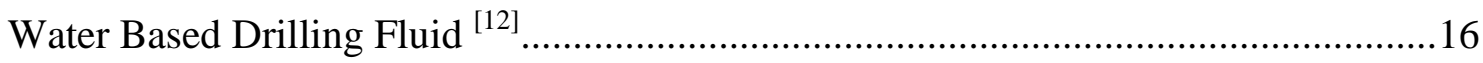

Table 4.1: Composition for a Water-Based Lignosulfonate Base Mud ........................19

Table 4.2: Characteristics of the Crude Oil Samples ..................................................22

Table 5.1: Properties and Sample Names of the Lubricants .......................................38

Table 5.2: Overall Negative and Positive Effects of Lubricants.....................69

Table A.1.: Test Results of LUBE-1 Added Alone to the Water-Based................77 Lignosulfonate Mud.

Table A.2.: Test Results of LUBE-2 Added Alone to the Water-Based Lignosulfonate

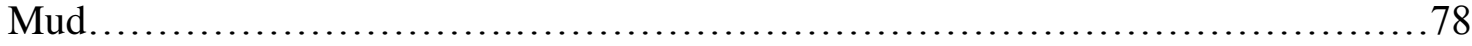

Table A.3.: Test Results of LUBE-3 Added Alone to the Water-Based Lignosulfonate

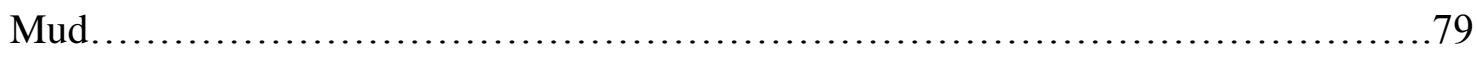

Table A.4.: Test Results of LIGHT OIL Added Alone to the Water-Based Lignosulfonate Mud.................................................... 80

Table A.5.: Test Results of HEAVY OIL Added Alone to the Water-Based

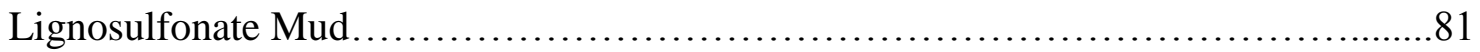

Table A.6.: Test Results of DIESEL Added Alone to the Water-Based Lignosulfonate Mud.................................................. 82

Table A.7.: Test Results of LUBE-2 Mixed with LIGHT OIL and Added to the WaterBased Lignosulfonate Mud............................................. 83 
Table A.8.: Test Results of LUBE-2 Mixed with LIGHT OIL and Added to the WaterBased Lignosulfonate Mud................................................ 84

Table A.9.: Test Results of LUBE-3 Mixed with LIGHT OIL and Added to the WaterBased Lignosulfonate Mud............................................... 85

Table A.10.: Test Results of LUBE-1/LUBE-2/LUBE-3 Mixed with HEAVY OIL and Added to the Water-Based Lignosulfonate Mud................................ 86

Table A.11.: Test Results of LUBE-1/LUBE-2/LUBE-3 Mixed with DIESEL and Added to the Water-Based Lignosulfonate Mud.................................. 87

Table A.12.: Test Results of Influence of Calcium Ion on Mud Properties and Lubricity.................................................................... 88

Table A.13.: Test Results of Influence of $\mathrm{pH}$ on Mud Properties and Lubricity

Table A.14.: Test Results of Influence of Chloride Ion on Mud Properties and Lubricity .90

Table A.15.: Test Results of Influence of Mud Weight without Lubricants on Mud Properties and Lubricity.

Table A.16.: Test Results of Influence of Mud Weight with LUBE-1 Mixed with LIGHT OIL on Mud Properties and Lubricity.

Table A.17.: Test Results of Influence of Mud Weight with LUBE-2 Mixed with LIGHT OIL on Mud Properties and Lubricity 93

Table A.18.: Test Results of Influence of Mud Weight with LUBE-3 Mixed with LIGHT OIL on Mud Properties and Lubricity.....

Table A.19.: Repeatability of the Test Results of LUBE-2 Added Alone to the WaterBased Lignosulfonate Mud. .... 


\section{CHAPTER 1}

\section{INTRODUCTION}

In the process of drilling extended-reach, directional and instable hole well profiles, the friction caused by dog-legs, keyseats, bit balling and hole instability, causes excessive torque values. The friction and high torque and drag, that result from drill string and wellbore/casing interaction, causes overpulls in trip-outs, pipe stucks and even lose out the well. Also, inside the casing, energy that is formed from metal-metal surface contact between drill string and casing, causes casing wear.

Oil-based drilling fluids and synthetic-based drilling fluids, generally produces lower friction and lower torque values than the water-based drilling fluids while drilling the well. However, the use of oil-based drilling fluids and synthetic-based drilling fluids, is severely limited because of high costs and environmental concerns. As a solution, it is seen that, it would be advantageous to identify a water-based drilling fluid system with addition of lubricants which is environmentally friendly, cost effective and as lubricious as oil-based drilling fluids and synthetic-based drilling fluids. [1]

Lubricants can be divided into two categories; solid lubricants and liquid lubricants. Solid lubricants act like ball bearings, that interfere with the contact surfaces without bonding to them. The performance of solid lubricants is independent from the drillingfluid type as they do not bond. [1] On the other hand, liquid lubricants form a film between the two surfaces that are; drill string and casing/wellbore, which is thick enough to mask surface roughness and strong enough to fight with high compressional forces, minimizing the contact area and so the friction and torque. As liquid lubricants 
interacts with other surface active additives in the drilling fluid, their performance depends on the concentration of the lubricant. [1]

In this study, liquid lubricants are used as friction reducers. Three types of commercial chemical lubricants which are; triglycerid and vegetable oil based, fatty acid and glycerid based and polypropylene glycol based lubricants. On the other hand, diesel oil, and crude oil, with different API gravity, paraffin and asphaltic value samples are tested. Diesel oil and crude oil are much cheaper than the commercial lubricants and they are easy to obtain in oil/gas fields. However, they are not as lubricious as commercial chemical lubricants. Therefore, it is decided to combine chemical lubricants and crude oils in our water-based drilling fluid and to determine the best composition which has good lubricity performance and low cost.

Water-based lignosulfonate mud is chosen as our base drilling fluid. Water-based lignosulfonate mud is the most common and one of the cheapest water-based drilling fluid systems. Also, this system is not strong enough to withstand and fight with high torque and its lubricity performance is insufficient. Therefore, this system is considered as our base mud and add different lubricants to determine the highest lubricant performances. Additives of this base system are; treated bentonite, lignosulfonate, $\mathrm{CMC}, \mathrm{NaOH}$. We add OCMA and barite to this system and before testing, we aged the drilling fluid samples for 16 hours at hot rolling conditions at $150 \mathrm{~F}$, in order to provide the field conditions.

Ofite Lubricity Tester is the equipment that we use to evaluate the lubricity values of the samples. Ofite Lubricity Tester gives us the torque value of the samples in lb-in. We use calibration constant and calculate the coefficient of friction (COF). We use COF to compare the lubricity performance of the samples.

In order to get the best performance from the lubricants, effects of the lubricants on physical and chemical mud properties are looked up. Therefore, drilling fluid samples 
are tested on mud reology; that consists of plastic viscosity (PV), yield point (YP) and gel strengths, API fluid loss of mud, foam forming potential and cheesing/greasing potential.

Drilling fluids samples are also been tested for the influence of the mud properties on lubricants in order to see the effects of the lubricants in chemical and physical contamination of the drilling fluids and at high mud density. Therefore, the performance of the lubricants is examined at high $\mathrm{pH}$, high calcium ion content, high chloride content and high density drilling fluid samples. 


\section{CHAPTER 2}

\section{LITERATURE REVIEW}

\subsection{Overview of Lubricity Analysis}

High torque and drag become one of the most important issues of drilling industry as drilling in extended-reach and directional wells gain popularity. We can mention that is true for water-based drilling fluid systems as they give higher coefficient of friction values and so high torque and drag, between drill string and formation/casing, than compared to oil-based drilling fluids and synthetic-based drilling fluids. However, oilbased drilling fluids and synthetic-based drilling fluids still have environmental issues and are not so cost effective. Therefore, it would be more advantageous to find lubricant-treated water-based drilling fluids which are more environmental friendly, lubricious and cost effective. [1]

In order to find the best lubricant-treated water-based mud composition, studies were made with different water-based drilling fluid systems, different lubricants, using different experimental approaches.

Growcock, Fredrick, Reece, Green and Ruffin [1] tested three unweighted drilling fluid systems, which are gel(bentonite)/water, PAC (polymer-based), and lignosulfonate based drilling-fluid system, adding various lubricants with the amount of 3\%. For testing lubricity, they used modified Temco Lubricity Evaluation Monitor (LEM) to test as shown in Fig. 2.1. The modified LEM was used to measure the coefficient of friction between a flat contact surface and a rotating bob which is made of steel that is typical of drill pipe in a circulating drilling fluid. The rotating bob has a rotation of $150 \mathrm{rev} / \mathrm{min}$ 
and a $40 \mathrm{lb}$ weight was applied between sandstone and steel. Test gives a torque reading in in.-lb and they converted these readings to COF to compare lubricity values. [1]

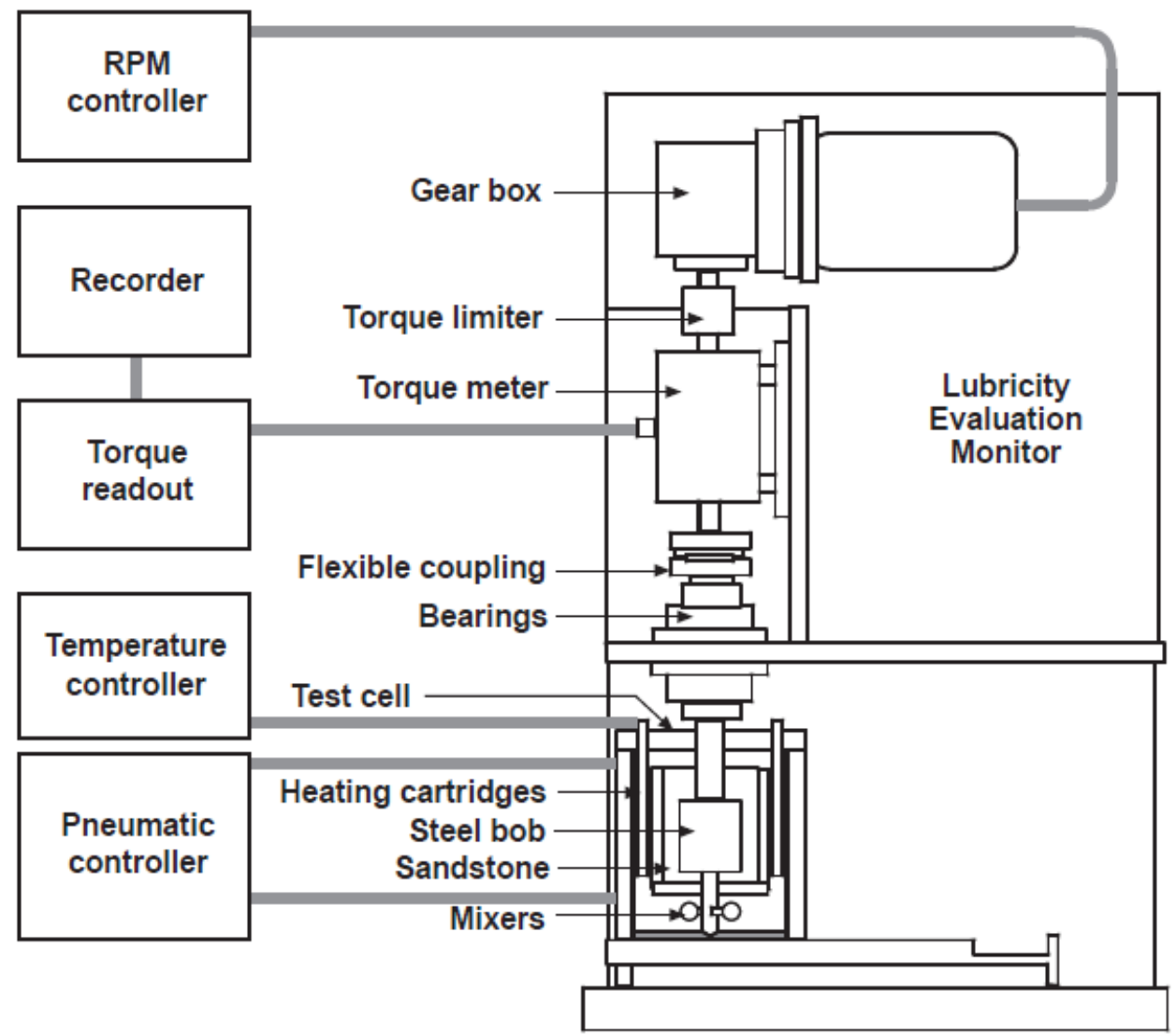

Figure 2.1: Modified Lubricity Evaluation Monitor ${ }^{[1]}$

As shown in Table 2.1, lubricity test results showed that most of the lubricants reduced the coefficient of friction of the base mud by more than $30 \%$ with the addition of $3 \%$ lubricants. They also saw that some lubricants are less effective in polymer-based drilling fluids than clay-based drilling fluids and surprisingly no lubricants appear to be effective in lignosulfonate drilling fluid. 
Table 2.1: Effect of Base Mud on Lubricant Performance ${ }^{[1]}$

\begin{tabular}{|l|c|c|}
\hline \multicolumn{1}{|c|}{ Base Mud } & COF & Typical \% $\boldsymbol{\Delta} \boldsymbol{C O F}$ \\
\hline Water & 0.7 & -50 \\
\hline Gel/Water & 0.7 & -40 \\
\hline PAC & 0.4 & -30 \\
\hline PHPA & 0.3 & -15 \\
\hline Lignosulfonate & 0.27 & 0 \\
\hline
\end{tabular}

Quigley, Dzialowski and Zamora [2] used an operational wellbore friction simulator (WBFS) shown in Fig.2.2, that uses full-scale components for measuring torque and drag. The WBFS was used to predict friction coefficients of unweighted lignosulfonate drilling fluid with and without a lubricant. For half of the test simulated cutting beds were added.

It is marked that Although, the WBFS can simulate operating conditions better that small-scale lubricity testers, lubricity results from WBFS lubricity tests, generally agree with the results from small-scale lubricity testers. They also concluded that, cutting beds can reduce friction coefficient and drag friction coefficient is reduced by tool joint rotation [2] 

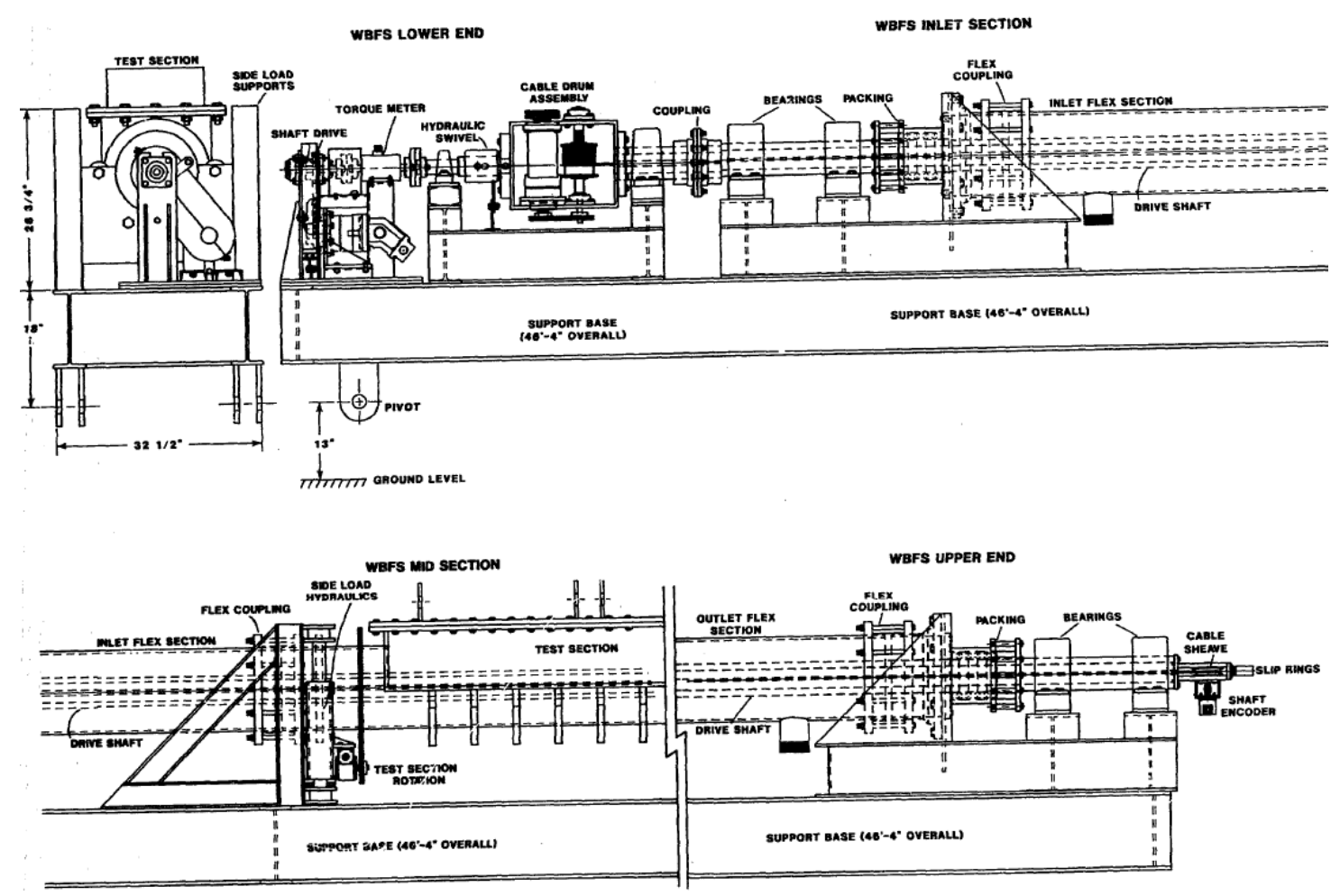

Figure 2.2: WBFS Overall View ${ }^{[1]}$

Tailleur [3] run a Timken Lubricant Tester to measure lubricity of the extreme pressure drilling fluids they designed. He looked for a longer bit bearing life and with a field experience, he proved that if the lubricating properties of the mud can be improved, they will lengthen bit bearing life, so enhance the drilling cost reduction.

LEM III lubricity test apparatus (Fig. 2.3) is another lubricity tester that the effect of coefficient of friction for metal-metal surfaces can be tested. Knox and Jiang [4] used this tester to measure lubricity values for various lubricants which were added 1 and $3 \%$ $\mathrm{v} / \mathrm{v}$, for completion brines and low solids water-based muds. He also tested for cheesing/greasing and foaming potential of the samples. 


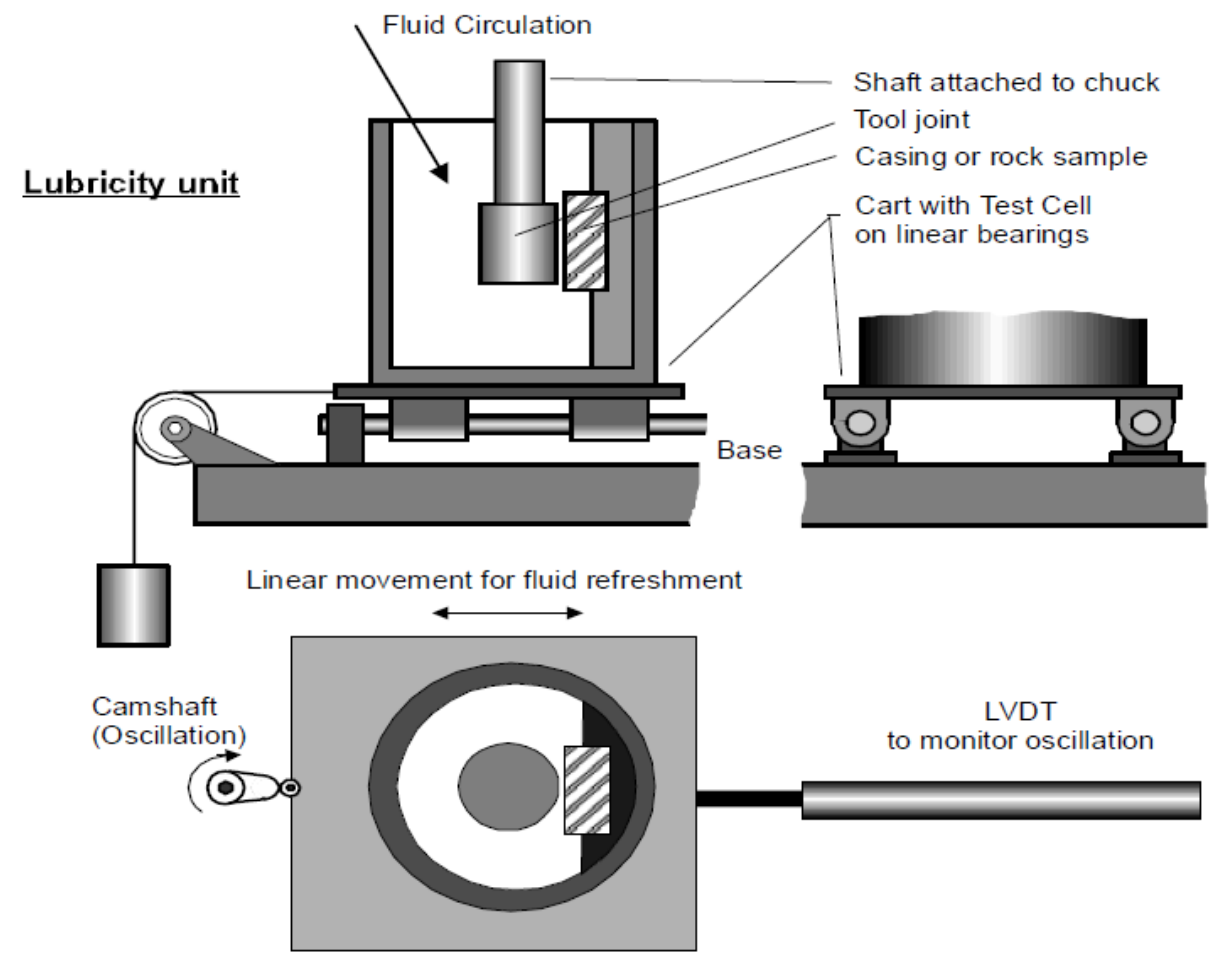

\section{Technical Data \\ Controlled Parameters: \\ Tool Joint rotation \\ Camshaft rotation \\ Contact force \\ Fluid flowrate}

Measured by computer and calculated value

Torque

Coefficient of friction

\section{Scale-up Parameters}

Rotation

Tool Joint $63 / 8 " \quad 40-120 \mathrm{rpm}$

Bob 30 mm Dia. 200 - 650 rpm

Camschaft rotation $0-60 \mathrm{rpm}$

Contact force

Tool Joint 18" $300-1000 \mathrm{lbf}$

Bob $38 \mathrm{~mm}$ long $11-38 \mathrm{kG}$

Fluid flowrate not scaled
Wellbore Type

Casing

Rock sample

Tool joint (Bob)

Carbon steel

Surface: smooth rough $(\sim 250 \mu \mathrm{m})$

Figure 2.3: LEM III Lubricity Test Unit ${ }^{[4]}$

Schamp, Estes and Keller [5] used three different torque reducing agents including drilling fluid base oil, liquid/solid lubricants and mechanical means. After a series of lubricity analysis, they found that solid lubricants brought on plugging problems with BHA components and not that much lubricious, liquid lubricants achieved field torque reductions of $5-15 \%$ when added concentrations of $2 \%$ to $6 \%$, and come up with the best answer for mechanical torque reduction tools, showing the largest reduction in torque values, but are very expensive, so necessity should be considered. 
Differential sticking is one of the major problems of the drilling industry and fairly related with the lubricity of the drilling fluid. Isambourg, Elf, Benaissa and Marti [6] used a differential sticking and lubricity apparatus to measure the coefficient of friction between metal and mud cake which was illustrated in Fig. 2.4. The device also measures the variation of mud filter cake pore pressure and permeability and sticking time. They evaluated both water and oil based drilling fluids' differential sticking potential. They found that accurate coefficients of friction between drill pipe and mud cake under laboratory simulated down hole conditions and differential sticking is affected by permeability and cake compaction, more than cake thickness.

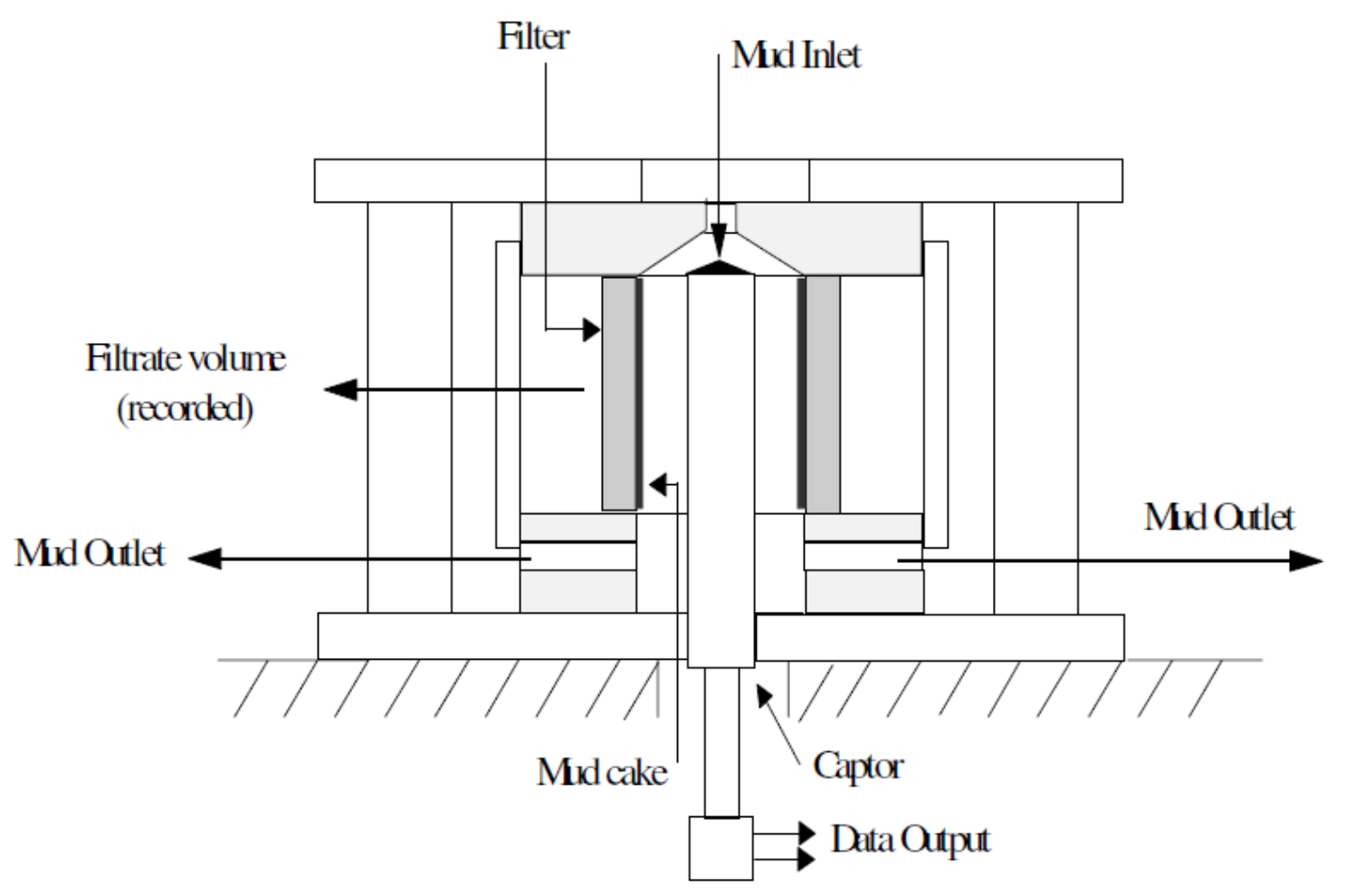

Figure 2.4: Differential Pressure Sticking and Friction Measurement Cell ${ }^{[6]}$

Reid, Meeten, Way, Clark, Chambers, Glimour and Sanders [7] used another differential sticking test device, called stickance tester shown in Fig. 2.5. This tester can 
be seen as a high temperature/high pressure (HPHT) fluid-loss cell that allows a metal sphere in contact with a mud filter cake and measure the torque value in order to rotate the metal sphere free from the mud filter cake. They study the effect of the lubricants on differential sticking and resulted that lubricants coat metal surfaces that reduces the adhesion of steel to the mud filter cake, makes better fluid loss control and reduces the yield stress of the mud filter cake which results thinner mud cakes and so less probability to differential stuck. [7] Effect of various lubricants in stickance is shown in Fig. 2.6.

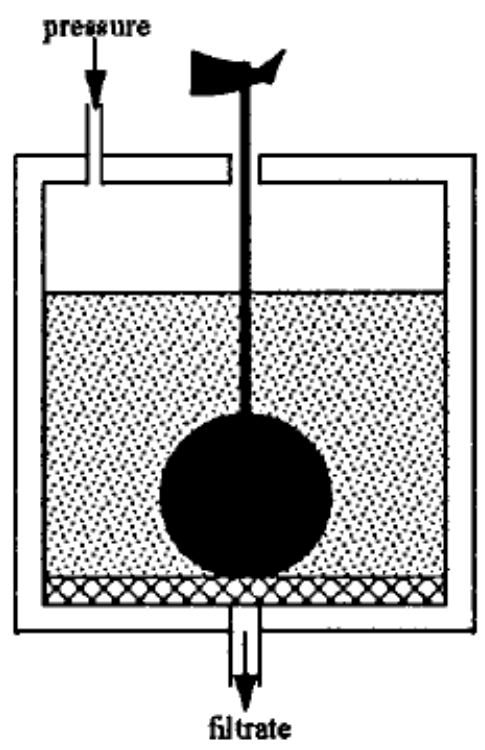

Figure 2.5: Schematic Diagram of the Stickance Tester ${ }^{[7]}$ 


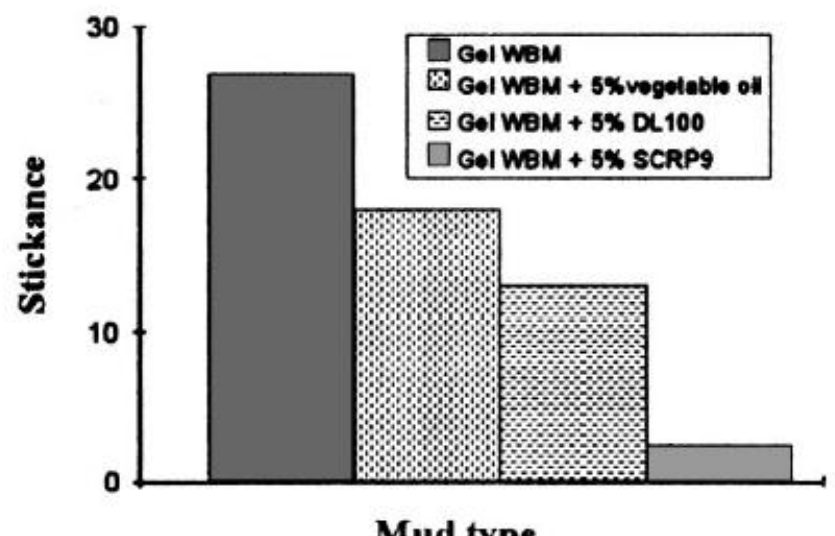

Mud type

Figure 2.6: Effect of Lubricants ${ }^{[7]}$

For water-based muds, environmentally accepted lubricants were compared with diesel oil and mineral oil based products by Kercheville, Hinds and Clements [8]. Coefficient of friction values were used to measure the lubricating properties of the muds. They found that mineral oil and diesel oil give similar lubricity values in mud, and biodegradable lubricants shows better than them for both torque reduction and extreme pressure lubrication (film strength). They also concluded that diesel oil, mineral oil and environmentally acceptable lubricants reduce the risk of differential stuck and can both be successfully used as spotting drilling fluids. [8]

Sifferman, Muijs, Fanta, Felker and Erhan [9] designed a special lubricity reduction system, using starch-lubricant compositions which were non-toxic, environmental and produce stable dispersions in water based drilling fluids. They used jet cooking technique to produce aqueous starch dispersion containing 1-10 microns diameter lubricant droplets by mixing starch, water and lubricant. They observed that $0.5 \%$ lubricant containing muds formulated with the starch-lubricant compositions, performed better than a conventional drilling fluids containing only $3 \%$ lubricant. They also found that, drilling fluids with the starch-lubricant compositions have better API and HTHP fluid loss properties, also, starch is environmentally safer, cost effective and can be 
transported easier. In Fig. 2.7, re-dispersed starch-lubricant powder is shown at $10 \%$ concentration in water. White circles show 1-8 microns lubricant droplets.

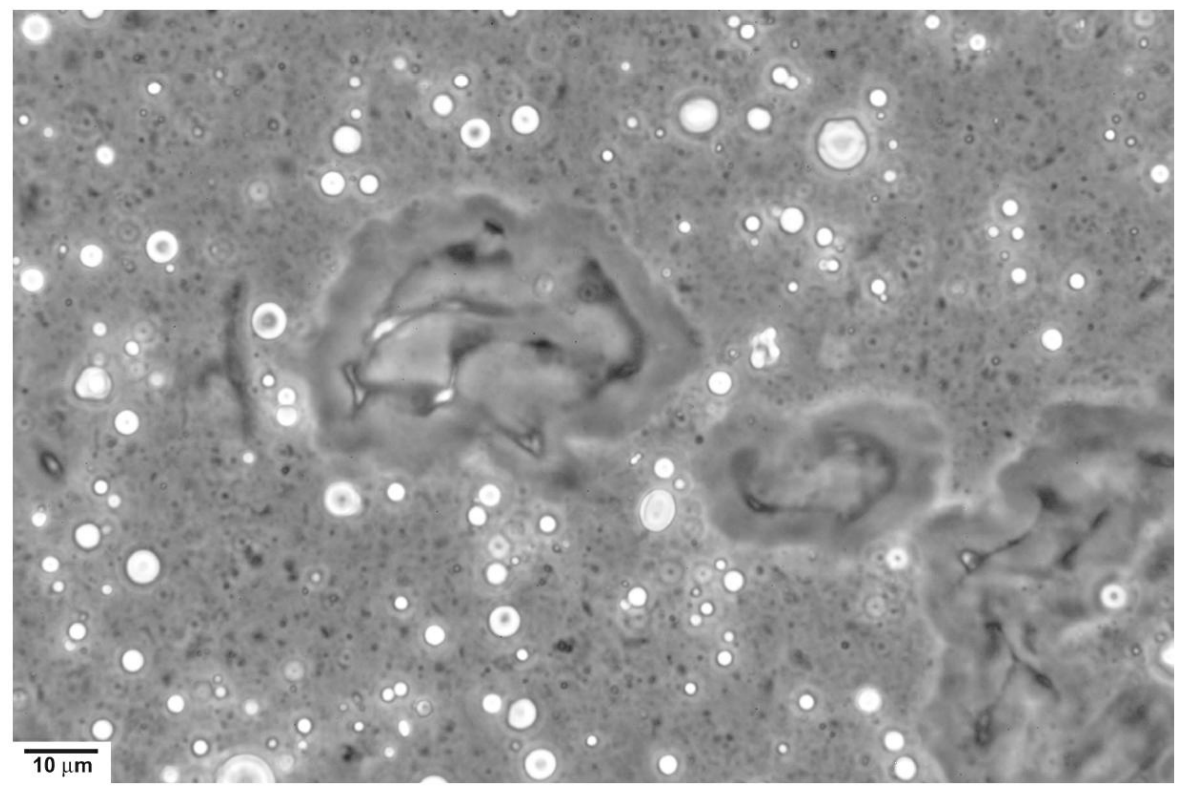

Figure 2.7: A 10\% Aqueous Dispersion of Starch-Lubricant ${ }^{[9]}$

\subsection{Effects of Lubricants on Mud Properties}

Lubricants may have some positive and negative effects on mud properties like; mud reology, API fluid loss, foaming potential, cheesing/greasing potential and some chemical properties. Those effects are very important to benefit from the lubricant completely.

Tyldsley [10] performed an application of a vegetable oil derivative lubricant called $\mathrm{SSP}$, to overcome the problems of torque and drag in drilling deviated wells. He came up with a result that $30 \%$ of reduction in torque values were experiences after adding SSP. He also concluded that SSP, helped to stabilize the lignosulfonate drilling fluid systems by lowering the API fluid loss. However, the results showed that SSP raised the 
yield point value of the mud. Effects of diesel and SSP in various mud systems on some mud properties can be observed in Table 2.2.

Table 2.2: Rheology, Fluid Loss Comparisons between Diesel and SSP ${ }^{[10]}$

\begin{tabular}{|c|c|c|c|c|c|c|c|}
\hline KCL Polymer & 600 & 300 & AV & PV & YP & $\begin{array}{l}\text { API } \\
\text { F.L. }\end{array}$ & $\begin{array}{c}\text { Falex } \\
\text { Breakdown (lbs) }\end{array}$ \\
\hline Base Mud & 18 & 9 & 9 & 9 & 0 & 6.6 & 2100 \\
\hline with DIESEL (10\%) & 22 & 12 & 11 & 10 & 2 & 4.6 & 3000 \\
\hline with SSP (10\%) & 20 & 11 & 10 & 9 & 2 & 4.6 & $>4500$ \\
\hline \multicolumn{8}{|l|}{ Low Lime } \\
\hline Base Mud & 12 & 6 & 6 & 6 & 0 & 6.8 & 2200 \\
\hline with DIESEL (10\%) & 18 & 10 & 9 & 8 & 2 & 5.4 & 3200 \\
\hline with SSP (10\%) & 26 & 15 & 13 & 11 & 4 & 5.2 & $>4500$ \\
\hline \multicolumn{8}{|l|}{ GYP-LIG } \\
\hline Base Mud & 21 & 12 & 11 & 9 & 3 & 16.6 & 2400 \\
\hline with DIESEL (10\%) & 24 & 14 & 12 & 12 & 4 & 11.3 & 2450 \\
\hline with SSP (10\%) & 25 & 15 & 13 & 10 & 5 & 10.2 & $>4500$ \\
\hline
\end{tabular}

In the research of Maldia and Wojtanowicz [14], lubricating properties are tested with a medium-scale borehole friction tester with a dynamic filtration apparatus which showed the coefficients of friction is affected by mud filter cake, mud quality, and lubricant additions. Water based drilling fluids and oil based drilling fluid are tested for lubricity, effects of drilled solids and chemical treatment. In some samples, they resulted with high rheological properties of muds. They also concluded that in low-solids drilling fluids, addition of lubricants showed better lubricating performance that high-solids drilling fluids.

Foxenberg, Ali, Long and Vian [15] presented a new environmentally acceptable lubricant that is compatible with completion and workover fluids. This lubricant is soluble in most completion brines and in high hardness conditions, (magnesium and calcium) this product does not cheese or grease, does not add to grease or oil content and is thermally stable. It is also compatible with the workover and completion fluid 
additives like biocides, oxygen scavengers, corrosion and scale inhibitors. However, they saw that this lubricant does produce foam especially in higher calcium brines, so they suggest taking care of this problem using defoamers. [15]

In the research of Argillier, Audibert, Janssen and Demoulin [16], a biodegradable and non-toxic ester based lubricant was described. Together with the good lubricity performance of this product, they saw that it is dispersable in water based mud, does not affect drilling fluid rheology, causes no cheesing or greasing, and as a positive effect, the lubricant improves the API filter loss reduction of the mud. Influence of addition of this ester based lubricant on rheological and filtration properties of a non dispersed water based mud is shown in Table 2.3.

Table 2.3: Influence of Ester Based Lubricant on Rheological and Filtration Properties of a Non-Dispersed Water Based Mud ${ }^{[16]}$

\begin{tabular}{|c|c|c|c|c|}
\hline WBM & \multicolumn{2}{|c|}{ before ageing } & \multicolumn{2}{c|}{ after $16 \mathrm{~h}$ at $100{ }^{\circ} \mathrm{C}$} \\
\hline & Ref & $1 \%$ EBL & Ref & $1 \%$ EBL \\
\hline Appearent Viscosity & 23 & 23 & 17 & 20 \\
\hline Plastic Viscosity & 11 & 11 & 8 & 8 \\
\hline Yield Point & 24 & 24 & 18 & 24 \\
\hline Gel 0/10 & $12 / 15$ & $12 / 15$ & $9 / 12$ & $11 / 13$ \\
\hline API Filtrate & 11.5 & 8 & 15 & 8 \\
\hline
\end{tabular}

\subsection{Influence of Mud Properties on Lubricity}

Drilling fluid type, additives and properties like calcium, $\mathrm{pH}$, salt, and mud weight may have negative and positive influence on mud's lubricity values. High and low values of these properties should be considered to get the best output from the lubricant. 
Dzialowski, Hale and Mahajan [11] investigated the torque and drag problems of shales as their physical and chemical properties behave differently than sandstone and metal. The interaction between mud and shale can change the chemical and mechanical properties of shale and so affects the lubricity of shale and its wear characteristics. They used a special lubricity test apparatus to test the lubricity values and wear comparing Pierre shale and Berea sandstone. They concluded that coefficient of friction values of shale were increased by additions of $\mathrm{KCl}$ and $\mathrm{NaCl}$ salts. $\mathrm{KCl}$ seemed more effective in wear reduction and lubricity values than $\mathrm{NaCl}$. They also tested for different concentrations of barite and bentonite solids, and saw no effect on wear rates and coefficient of friction values.

In the study of Skalle, Backe, Lyomov, Kilaas, Dyrli and Sveen [12], solid microbeads are investigated as a lubricant in drilling fluids. It is known that mud additives like bentonite $\&$ barite, and cuttings influence the friction values of the drilling fluid. Also, there are commercial large beads, being used as a solid lubricant, but they mostly be filtered out in solids control equipments. Therefore, they decided to use a modified lubricity tester to test smaller polymer microbeads as a lubricant in water based drilling fluids. Various, 7-50 $\mu \mathrm{m}$, sized spherical monosized microbeads were tested and coefficient of friction were calculated. The results of these mixtures are shown in Table 2.4. Also, the lubricity values of bentonite and barite were tested as shown in Fig 2.8 and Fig. 2.9. Bentonite was added in a distilled water in concentrations of $0.5 \%$ to $2 \%$ $(\mathrm{v} / \mathrm{v})$ and caused to increase the friction value by $35 \%$. Barite, in $1 \%$ to $6 \%(\mathrm{v} / \mathrm{v})$ concentrations, reduced the frictions of an unweighted water based drilling fluid up to 25\%. [12] 
Table 2.4: Friction Coefficients with 1 vol\% Bead Concentration in an Unweighted Water Based Drilling Fluid ${ }^{[12]}$

\begin{tabular}{|c|c|c|c|c|c|c|c|c|}
\hline Test No. & Mud & B-03* & B-16 & B-17 & B-18 & B-14 & B-19 & B-20 \\
\hline 1 & 0.216 & 0.137 & 0.139 & 0.144 & 0.142 & 0.175 & 0.172 & 0.162 \\
\hline 2 & 0.215 & 0.126 & 0.126 & 0.135 & 0.136 & 0.17 & 0.168 & 0.165 \\
\hline 3 & 0.209 & 0.129 & 0.121 & 0.134 & 0.131 & 0.171 & 0.176 & 0.174 \\
\hline 4 & 0.219 & & & & & & & \\
\hline Average & 0.215 & 0.131 & 0.129 & 0.138 & 0.136 & 0.172 & 0.172 & 0.167 \\
\hline \% red** & & 39 & 40 & 36 & 37 & 20 & 20 & 22 \\
\hline St.dev. & 0.004 & 0.006 & 0.009 & 0.006 & 0.006 & 0.003 & 0.004 & 0.006 \\
\hline \% dev.*** & 2.3 & 4.2 & 6.9 & 3.6 & 4 & 1.4 & 2.3 & 3.6 \\
\hline
\end{tabular}

*Bead number

$* * \%$ reduction compared to unweightes mud without beads

$* * * \%$ difference between max. and min. measured values divided by two

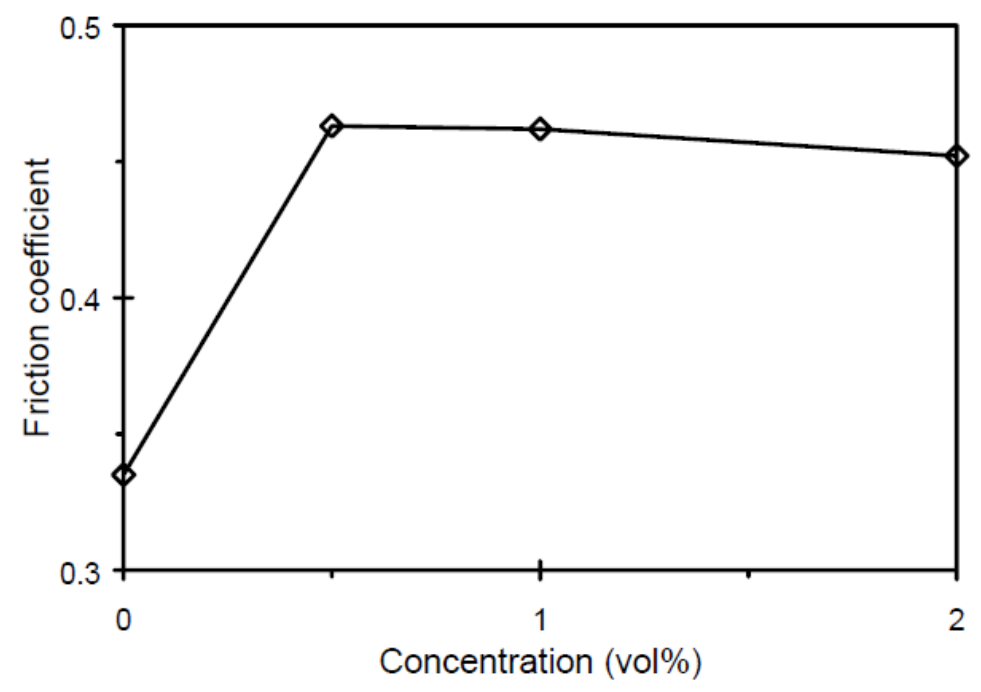

Figure 2.8: Effect of Adding Bentonite to Distilled Water ${ }^{[12]}$ 


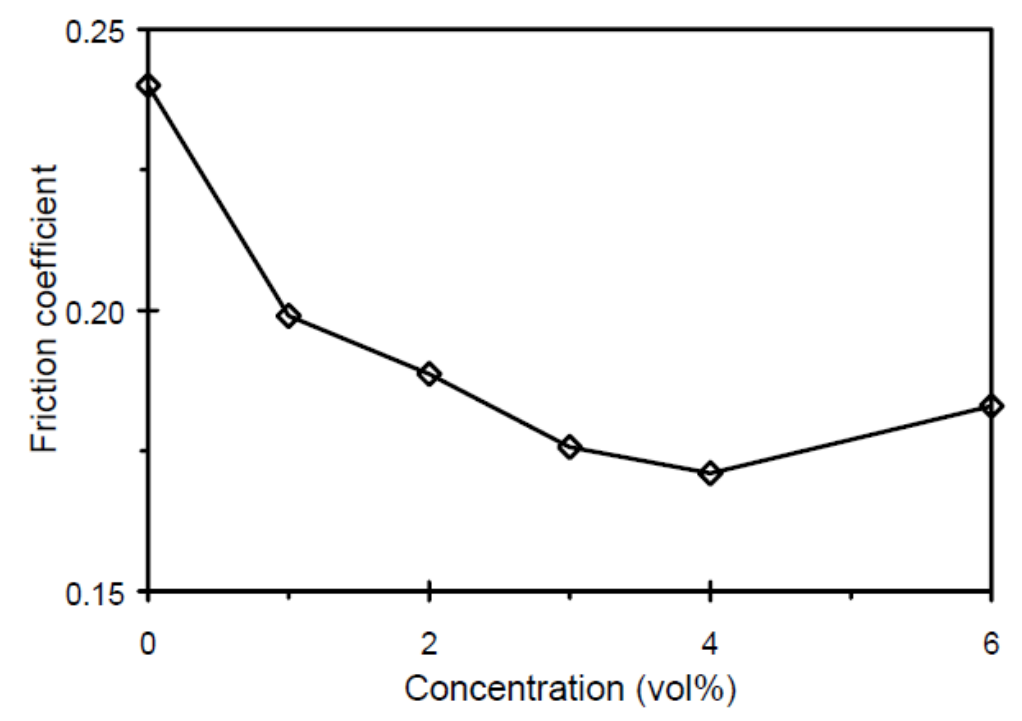

Figure 2.9: Effect of Adding Barite to an Unweighted Water Based Drilling Fluid ${ }^{[12]}$

Quigley [13], analyzed the coefficient frictions of various drilling fluid liquid lubricants evaluated in dispersed and non-dispersed mud systems using mud lubricity tester device. Drilling fluids had a mud density, varying 9 to $16 \mathrm{lb} / \mathrm{gal}$. He concluded that some lubricant additive can reduce bit balling, makes better filter cake and stabilize the wellbore, so these effects can decrease the torque and drag. He also noted that low density drilling fluids had a better coefficient of friction. [13]

The ester based lubricant, tested by Argillier, Audibert, Janssen and Demoulin [16], showed high lubricant performance even in high density drilling fluids or in presence of high salts or solids. This ester based lubricant remained stable and lubricious even at the temperature up to $160^{\circ} \mathrm{C}$. 


\section{CHAPTER 3}

\section{STATEMENT OF THE PROBLEM}

While drilling problematic formations with non-smooth well profiles, extended-reach and directional wells, the frictional forces between drill string and wellbore or casing can cause severe drilling problems, waste of equipment, time and money. High torque and drag may exceed the capabilities of drill string and casing and can cause pipe stuck and loss of the well.

Although high torque and drag are seen rarely in the wells drilled with oil-based drilling fluids and synthetic-based drilling fluids, these systems are not preferred because of the environmental problems and cost. Therefore, water based drilling fluids are favored to be used with proper lubricant additives.

The main focus in this study is to determine the best lubricant compositions which are added to the water based lignosulfonate drilling fluid, using liquid lubricants, that are three different types of commercial chemical lubricants; fatty acid and glycerid based, triglycerid and vegetable oil based and polypropylene glycol based, diesel oil, and crude oil, consisting different API gravity, paraffin and asphaltene values. Ofite Lubricity Tester is used to determine the most lubricious compositions with low cost.

Furthermore, effects of the lubricants on mud properties such as; API fluid loss of mud, mud rheology, cheesing/greasing and foam forming potential of the lubricants, and influence of mud properties on lubricant performance like calcium and salt content, $\mathrm{pH}$ and mud density are studied. 


\section{CHAPTER 4}

\section{EXPERIMENTAL SET-UP AND PROCEDURE}

\subsection{Sample Preparation}

Sample preparation in drilling fluids laboratory conditions is a serious matter for the reliability of the tests. In this section, mud additives, mixing and ageing procedures are summarized.

\subsubsection{Mud Additives}

To build up a water-based lignosulfonate mud; bentonite, $\mathrm{CMC}$, chrome free lignosulfonate, $\mathrm{NaOH}, \mathrm{OCMA}$ and barite are mixed as a base mud. As a lubricant, three types of chemical commercial lubricants are used which are, diesel and two samples of crude oil with different API gravities. Moreover, gypsum and $\mathrm{NaCl}$ are used to contaminate the mud to see the lubricant performance in contaminated media. Composition for the base mud can be seen in Table 4.1.

Table 4.5: Composition for a Water-Based Lignosulfonate Base Mud

\begin{tabular}{|l|c|}
\hline Additives & Amount \\
\hline Bentonite, lb/bbl & 20 \\
\hline CMC, lb/bbl & 2 \\
\hline Chrome Free Lignosulfonate, lb/bbl & 3 \\
\hline $\mathrm{NaOH}, \mathrm{lb} / \mathrm{bbl}$ & 0.75 \\
\hline OCMA, lb/bbl & 30 \\
\hline Barite, $\mathrm{lb} / \mathrm{bbl}$ & 10 \\
\hline
\end{tabular}




\subsubsection{Bentonite}

Bentonite is the main additive for most of the fresh water-based drilling fluid systems. It controls the API filter loss and rheological properties of the mud. The first rule for the thin, solid and impermeable mud cake, is using the quality bentonite in required composition. Effect of bentonite decreases in higher than $10000 \mathrm{mg} / \mathrm{lt} \mathrm{Cl}^{-}$ions and 240 $\mathrm{mg} / \mathrm{lt} \mathrm{Ca}^{+2}$ ions concentrations.

\subsubsection{CMC}

CMC is a filter loss agent in fresh water-based drilling fluids. It is a cellulose based anionic polymer, which is mostly used in the concentrations of $1-3 \mathrm{lb} / \mathrm{bbl}$. Effect of CMC decreases in higher than $30000 \mathrm{mg} / \mathrm{lt} \mathrm{Cl}^{-}$ions, $500 \mathrm{mg} / \mathrm{lt} \mathrm{Ca}^{+2}$ ions concentrations and in $300^{\circ} \mathrm{F}$ bottom hole temperatures.

\subsubsection{Chrome Free Lignosulfonate (CFL)}

CFL is a fresh water-based drilling fluid additive with an organic origin free of chrome. The first function of this additive is to decrease the rheological properties of the mud as a thinner. The second function is to help to decrease the filter loss. It makes maximum impact in 9-10 $\mathrm{pH}$ value. Effect of CFL decreases in $350^{\circ} \mathrm{F}$ bottom hole temperatures and decreases the $\mathrm{pH}$, when added to the drilling fluid system.

\subsubsection{Caustic Soda $(\mathrm{NaOH})$}

$\mathrm{NaOH}$ is used the increase the $\mathrm{pH}$ of the water-based drilling fluids. 


\subsubsection{Barite $\left(\mathrm{BaSO}_{4}\right)$}

Barite is used to increase density of all of the drilling fluid types. The specific gravity of barite is 4.2

\subsubsection{OCMA Clay}

OCMA Clay is not a conventional additive in drilling fluids compositions. It is composed of swelling, smectite type of minerals that represents the cuttings come from the formation. OCMA is used to adapt the well conditions to the laboratory.

\subsubsection{Gypsum $\left(\mathrm{CaSO}_{4}\right)$}

Gypsum is used for the treatment of carbonate/bicarbonate contamination in drilling fluids. $\mathrm{Ca}^{+2}$ ion precipitates the excess carbonate ions. In this study, it is used to contaminate the mud with high $\mathrm{Ca}^{+2}$ ions to see how lubricant performs in this condition.

\subsubsection{Sodium Chloride ( $\mathrm{NaCl})$}

$\mathrm{NaCl}$ is used in drilling problematic salt formations as a saturated salt drilling fluid and in drilling wells with hydrate formation risk as a secondary hydrate inhibitor. In this study, it is used to contaminate the mud with high $\mathrm{Cl}^{-}$ions to see how lubricant performs in this condition.

\subsubsection{Lubricant}

Lubricants are used to decrease the risk of pipe stuck and torque and drag values. They form a strong and lubricious film between drill string and formation or casing. In this 
study, three different types of chemical commercial lubricants are used which are fatty acid and glycerid based, triglycerid and vegetable oil based and polypropylene glycol based lubricants. Also, diesel oil, and crude oil, which consists of different API gravity, paraffin and asphaltene values, are used as a lubricant. In Table 4.2, the characteristics of the crude oil samples can be seen.

Table 4.6: Characteristics of the Crude Oil Samples

\begin{tabular}{|l|c|c|}
\cline { 2 - 3 } \multicolumn{1}{c|}{} & Crude Oil-1 & Crude Oil-2 \\
\hline API & 29,6 & 19,6 \\
\hline$\%$ water & 0,1 & 0,8 \\
\hline$\%$ deposit & 0,4 & 1 \\
\hline$\%$ paraffin & 7,14 & 7,31 \\
\hline$\%$ asphaltene & 3,73 & 11,97 \\
\hline$\%$ sulphur & 1,09 & 2,91 \\
\hline
\end{tabular}

\subsubsection{Mixing and Ageing}

Preparing the drilling fluid in the laboratory has to be done accurately. Before beginning to mix the fluid, additives are weighed using Precisa Balance which can measure in grams and up to two decimals. [17]

After weighing the additives Sterling Multimixer Model is used to mix the drilling fluid. [18] We add the ingredients in order. The order of the base mud is; bentonite, caustic, CMC, CFL, barite and OCMA. Lubricant is added in the last order.

After adding the additives, we mix the mud in Sterling Multimixer for 30 minutes. Later on, mud is filled into OFITE Ageing Cell which is stainless steel grade [19] and cell is put in an insulated and temperature controlled FANN Roller Oven Model 705 ES. [20] Sample is aged for 16 hours at $150{ }^{0} \mathrm{~F}$ to adapt the mud into well conditions. 


\subsection{Lubricity Test}

Frictional forces that resist motion come into play, when there is a relative motion between two contacting bodies. In order to decrease the torque caused by high frictional forces in drilling, lubricants are used in water-based drilling fluids. To test the performance of lubricants at laboratory conditions, lubricity test is designed to simulate the speed of the rotation of the drill string and the pressure which the drill string bears against the bore hole wall or casing. [21]

In this study, OFITE Lubricity Tester is used to measure the lubricating qualities of the drilling fluids, provide data to evaluate the quantity and type of the lubricating additives and predict the wear rates of the mechanical parts in the fluid systems. [21] Overview of OFITE Lubricity Tester can be seen in Figure 4.1.

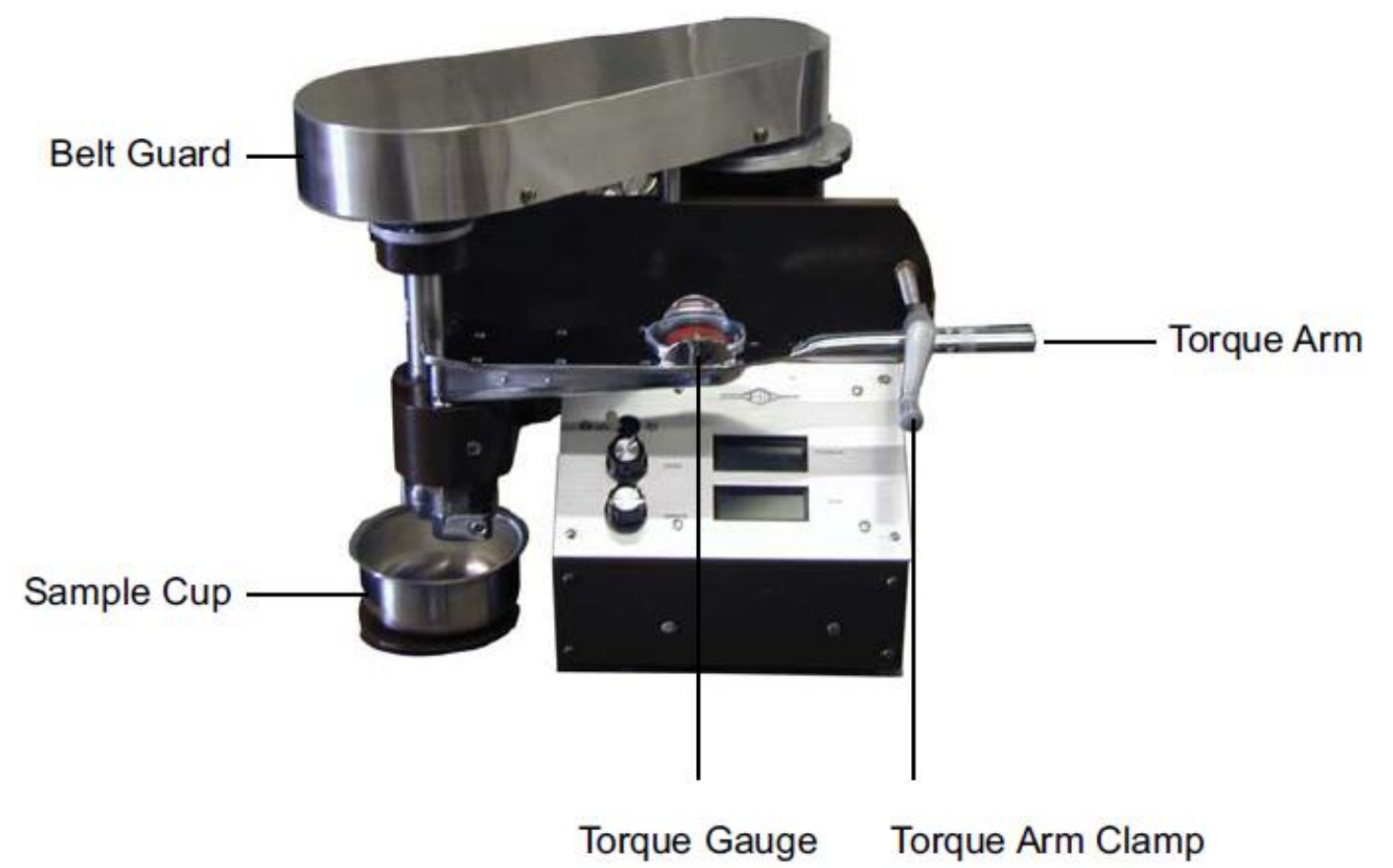

Figure 4.1: Overview of OFITE Lubricity Tester ${ }^{[21]}$ 
OFITE Lubricity Tester instrument includes four main components:

- Test ring for lubricity test.

- Test block for lubricity test.

- Torque wrench

- Sample cup

Basic steps of procedure required for running a OFITE Lubricity Tester are listed below [21]:

1. Clean the lubricity test ring and the lubricity test block with acetone and rinse them thoroughly with deionized water. All parts of the machine in the sample area must be clean before starting a test.

2. Place the lubricity test ring squarely onto the tapered portion of the main shaft. Make sure the ring seats squarely on the taper of the shaft.

3. Turn the power on and let the machine run for approximately 15 minutes.

4. As illustrated in Figure 4.2, place the lubricity test block in the block holder. Then, with the concave side facing out and align it with the test ring.

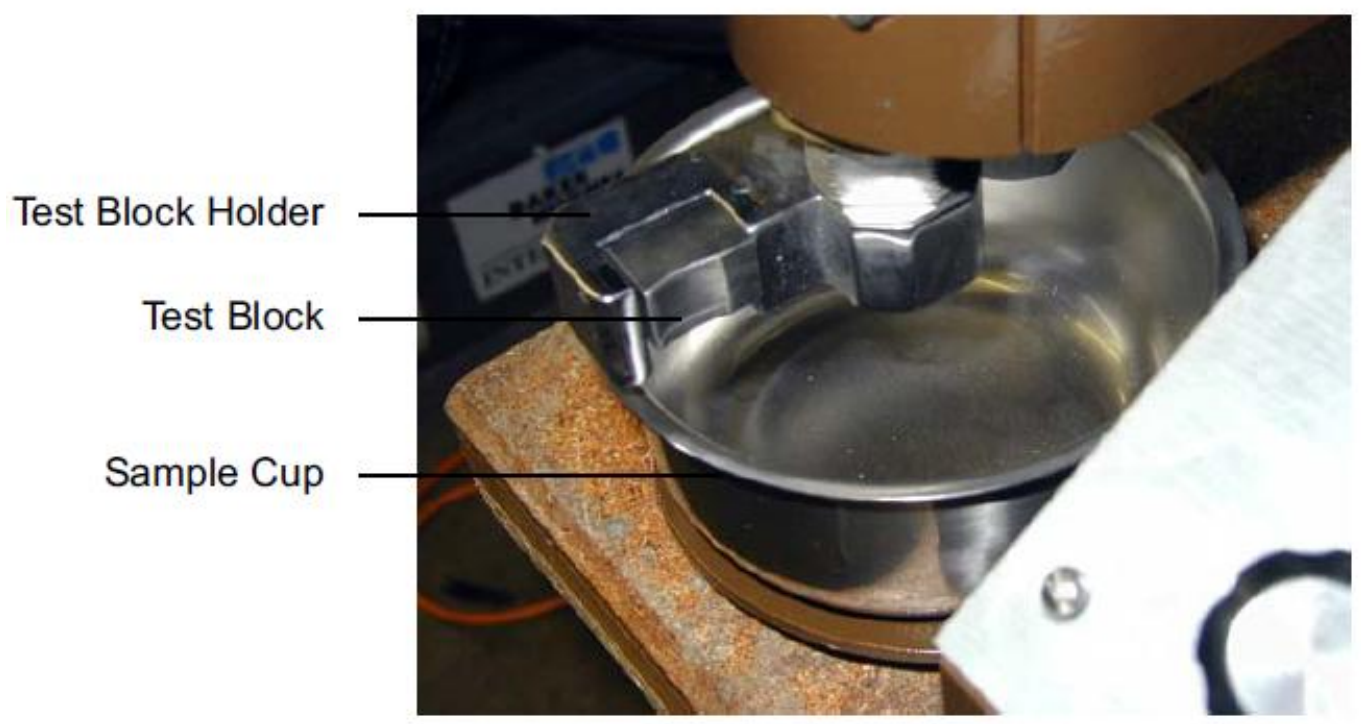

Figure 4.2: Placing Lubricity Test Block in the Block Holder ${ }^{[21]}$ 
5. Rotate the speed control knob until the indicator registers 60 RPM.

6. After the unit has been running for 15 minutes, rotate the torque zero adjustment knob until the torque registers zero. Run the unit approximately 5 more minutes and adjust again if required.

7. Fill the stainless steel sample cup with deionized water $(260-280 \mathrm{~mL})$ and place it on the lowered cup stand. Raise the cup stand until the test ring, test block, and block holder are fully submerged. Tighten the thumbscrew to secure the cup stand.

8. Position the torque arm so that it fits inside the concave portion of the torque arm clamp. Turn the torque adjust handle clockwise until the torque gauge on the arm reads 150 inch-pounds. If necessary, readjust the rotational speed to 60 RPM.

9. Let the machine run for 5 minutes and then record the torque reading. The torque reading $\left(\tau_{\text {water }}\right)$ should be $34 \pm 2$ (between 32 and 36 ).

Using this torque reading correction factor is calculated,

$$
C . F .=\tau_{S-\text { water }} / \tau_{\text {water }}
$$

where C.F , is correction factor, and $\tau_{S-\text { water }}$, is 34 in-lbs for this machine.

10. Rotate the torque adjustment handle counter-clockwise until the torque registers zero. Lower the cup stand and discard the fluid. Wipe any remaining fluid from the sample cup, block, block holder, and test ring.

11. Mix your test fluid $(260-280 \mathrm{~mL})$ for at least ten minutes. Pour the test fluid into the stainless steel cup. Place the cup on the stand and raise it until the block holder and test ring are fully immersed in the fluid. Secure the stand in place with the thumbscrew.

12. Turn the speed control knob until the indicator registers 60 RPM. Adjust the torque zero adjustment knob until the torque registers zero. Run the machine for approximately 5 minutes and adjust again if necessary. 
13. Turn the torque adjustment handle clockwise until 150 inch-pounds of torque have been applied to the test block. Let the machine run for 5 minutes.

14. After 5 minutes, record the torque reading and release the torque on the arm.

Using this torque reading $\left(\tau_{\text {reading }}\right)$ and correction factor, coefficient of friction is calculated,

C.O.F. $=\left(\tau_{\text {reading }} / 100\right) \times C . F$.

where, C.O.F., is coefficient of friction.

\subsection{Mud Properties}

In order to see the effects of lubricants on mud properties and the influence of mud properties on the lubricant performance, chemical and physical analysis of the drilling fluids are made.

\subsubsection{Chemical Analysis}

In this study, hydrogen ion concentration $(\mathrm{pH})$, chloride and calcium ion concentrations are tested for chemical analysis.

\subsubsection{Hydrogen Ion Concentration (pH)}

Determining hydrogen ion concentration $(\mathrm{pH})$, is one of the most important fundamentals of drilling fluids control. Solubility of various components, effectiveness of additives and clay interactions are all very dependent on $\mathrm{pH}$. [22]

There are two methods of measuring th $\mathrm{pH}$ of fresh water drilling fluids that are calorimetric method using plastic $\mathrm{pH}$ test strips and electrometric method using a glass electrode. 
In this study calorimetric method is prefered as the calorimetric method may not be so reliable. In the electrometric method OAKTON Waterproof pHTestr 2 consisting of a glass electrode system, electronic amplifier and a meter calibrated in $\mathrm{pH}$ units, is used. [23]

Basic steps of procedure required for using $\mathrm{pH}$ meter is listed below. [24]

1. Make the necessary adjustments to standardize the meter with suitable buffer solutions.

2. Insert the electrodes into the fluid contained in a small glass vessel. Stir the fluid around the electrodes by rotating the container.

3. Measure the fluid $\mathrm{pH}$ with the instrument. After the meter reading becomes constant, record the $\mathrm{pH}$ to the nearest 0.1 unit.

\subsubsection{Determining Chloride Ion Content}

To determine the chloride ion content in the mud filtrate, following materials are required:

- Silver nitrate solution, $0.0282 \mathrm{~N}$

- Potassium chromate indicator solution.

- $0.02 \mathrm{~N}$ sulfuric acid solution

- Phenolphthalein indicator solution

- Distilled water.

- Two graduated pipettes: $(1 \mathrm{ml} \& 10 \mathrm{ml})$

- Titration vessel, 100 to $150 \mathrm{ml}$

- Stirring rod.

Steps of procedure required for determining chloride ion content is listed below [22]: 
1. Measure $1 \mathrm{ml}$ of filtrate into a titration vessel. Add two or three drops of phenolphthalein solution. If the indicator turns pink, add acid drop by drop from pipette, while stirring, until the color is discharged.

2. Add $25 \mathrm{ml}$ of distilled water and 10 drops of potassium chromate solution. Stir continuously and titrate with standard silver nitrate solution drop by drop from the pipette, until the color changes from yellow to orange-red and persists for 30 sec.

3. Record the number of $\mathrm{ml}$ of silver nitrate required to reach the end point.

$$
\text { Chloride }(m g / l t)=\frac{m \text { Lof silver nitrate } \times 1000}{m \text { Lof filtrate }}
$$

\subsubsection{Determining Calcium Ion Content}

To determine the calcium ion content in the mud filtrate, following materials are required:

- EDTA (Standart Versanate) solution 0.01 M (1ml= $\left.400 \mathrm{mg} / \mathrm{lt} . \mathrm{Ca}^{++}\right)$

- $\mathrm{Ca}^{++}$indicator : hydroxy naphtol blue

- $1 \mathrm{~N} \mathrm{NaOH}$ solution

- Distilled water.

- Two graduated pipettes: $(1 \mathrm{ml} \& 10 \mathrm{ml})$

- Titration vessel, 100 to $150 \mathrm{ml}$

- Stirring rod.

Steps of procedure required for determining calcium ion content is listed below [24]:

1. Add $25 \mathrm{ml}$ of distilled water to the titration vessel.

2. Add $3 \mathrm{ml} 1 \mathrm{~N} \mathrm{NaOH}$ and Add one scoop of calcium indicator. If $\mathrm{Ca}++$ is present, the solution will turn pink and titrate sample with a versenate solution to a violet colored end point. 
4. Measure $1 \mathrm{ml}$ of filtrate into a titration vessel. If the color turns pink, titrate sample with a versenate solution to a violet colored end point and record the number of $\mathrm{ml}$ of versenate solution required.

Calcium $(m g / l t)=\frac{m L \text { of versenate solution } \times 400}{m \text { Lof filtrate }}$

\subsubsection{Physical Analysis}

In this study, density measurement, viscosity and gel strengths, filtration and foam forming measurement are tested for physical analysis.

\subsubsection{Density Measurement (Mud Weight)}

Density or a weight of a given volume of liquid is determined by using a mud balance. OFITE Metal Mud Balance is used in this study which permits accurate measurement with its graduated arm in specific gravity, lb/gal and lb/cuft. [25] Lb / cuft unit is used in this study. Overview of OFITE Metal Mud Balance is shown in Figure 4.3. 


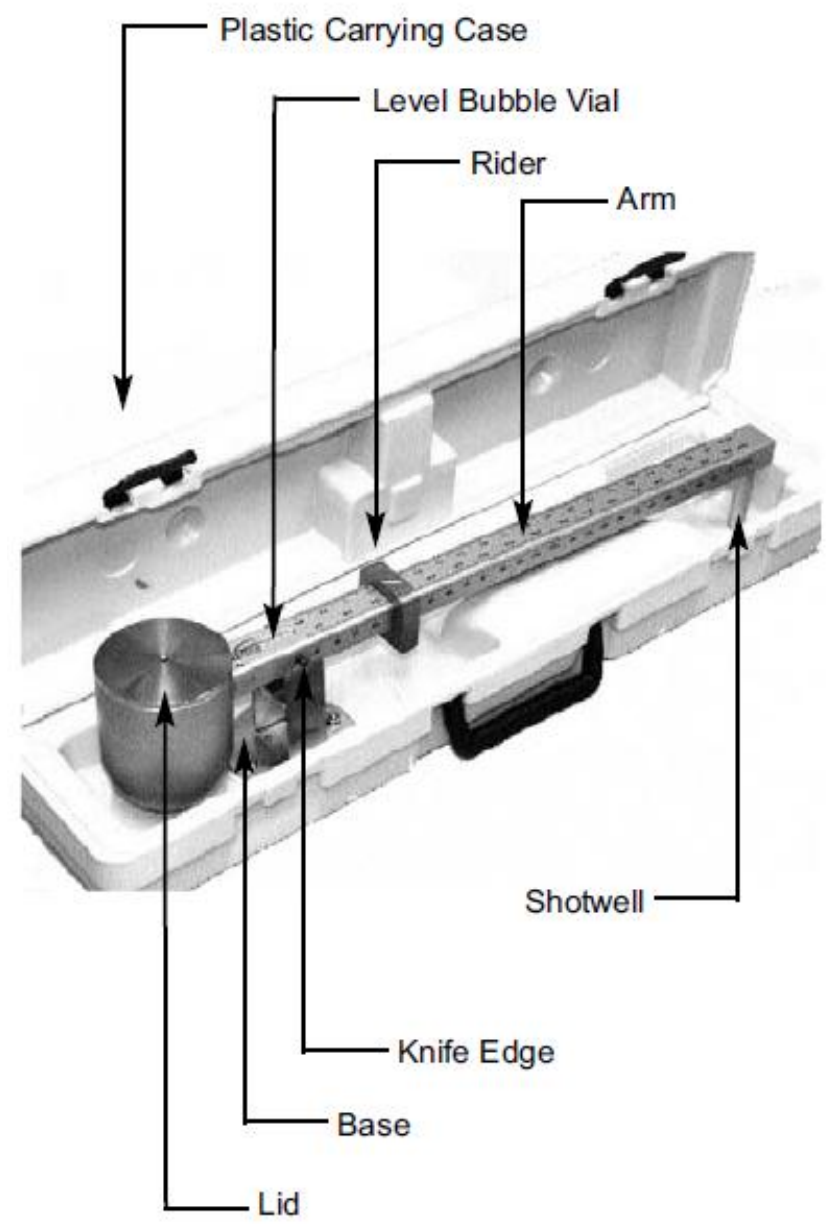

Figure 4.3: Overview of OFITE Metal Mud Balance ${ }^{[25]}$

Procedure required for determining mud weight is listed below [22]:

1. Remove the lid from the cup, and completely fill the cup with the mud to be tested.

2. Replace the lid and rotate until firmly seated, making sure some mud is expelled through the hole in the lid.

3. Wash the mud from the outside of the cup, and dry it.

4. Place the balance arm on the base, with the knife edge resting on the fulcrum. 
5. Move the rider until the graduated arm is level, as indicated by the level vial on the beam.

6. At the edge of the rider closest to the cup, read the density or weight of the mud.

7. Report the result to the nearest scale division, either in $\mathrm{lb} / \mathrm{gal}, \mathrm{lb} / \mathrm{ft} 3$, $\mathrm{psi} / 1,000 \mathrm{ft}$ of depth or Specific Gravity (SG).

\subsubsection{Rheological Analysis}

In the rheological analysis section, FANN Model 35SA Viscometer is used to measure plastic viscosity (PV), yield point (YP) and gel strengths. FANN Model 35SA Viscometer is a direct reading instrument where viscosity measurements are made when

the outer cylinder, rotating at a known velocity, causes a viscous drag to be exerted by the fluid, which creates a torque value on the bob. This torque is transmitted to a spring where its deflection is measured. [27]

FANN Model 35SA Viscometer is a six speed viscometer where the speed ranges from $3 \mathrm{rpm}$ to $600 \mathrm{rpm}$. Detailed cross section view of the viscometer is shown in Figure 4.4. 


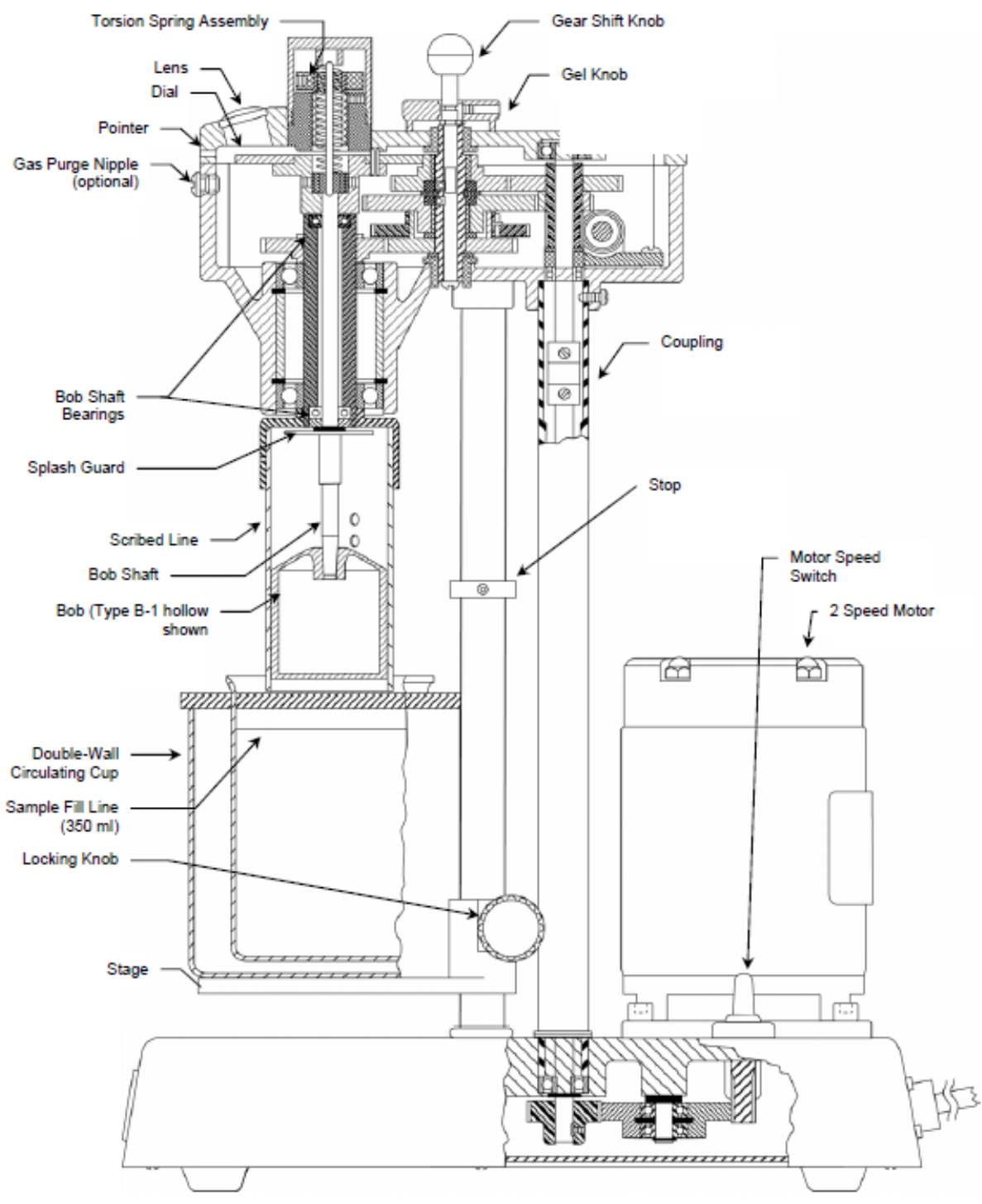

Figure 4.4: Cross Section View of FANN Model 35 Viscometer ${ }^{\text {[27] }}$

Procedure required for determining PV, YP and gel strengths, is listed below [26]:

1. Collect the drilling fluid sample.

2. Place the sample in a thermostatically controlled viscometer cup.

3. Immerse the viscometer rotor sleeve exactly to the scribed line.

4. Heat the sample to the selected temperature. (in this study, $150{ }^{0} \mathrm{~F}$ ) 
5. Rotate the viscometer sleeve at $600 \mathrm{rpm}$ until a steady dial reading is obtained. Record the dial reading $(\theta 600)$.

6. Rotate the viscometer sleeve at $300 \mathrm{rpm}$ until a steady dial reading is obtained. Record the dial reading $(\theta 300)$.

7. Stir the sample for 10 to 15 seconds at $600 \mathrm{rpm}$, then let the mud stand undisturbed for 10 seconds.

8. Rotate the viscometer sleeve at $3 \mathrm{rpm}$ until the maximum dial reading is obtained.

9. Record the maximum dial reading obtained as the 10 -second gel strength, $\mathrm{lbf} / 100 \mathrm{ft} 2$.

10. Restir the sample for 10 to 15 seconds at $600 \mathrm{rpm}$, then let the sample stand undisturbed for 10 minutes.

11. Rotate the viscometer sleeve at $3 \mathrm{rpm}$ until the maximum dial reading is obtained.

12. Record the maximum dial reading obtained as the 10 -minute gel strength, lbf/100 ft2.

Using $\theta 600$ and $\theta 300$ values, plastic viscosity and yield point and gel strengths are calculated:

$P V, c p=\theta 600-\theta 300$

$Y P, l b f / 100 f t^{2}=\theta 300-P V$

Gel Strength (10 sec), lbfflooft ${ }^{2}=$ Max. dial reading at $3 \mathrm{rpm}$

Gel Strength (10 $\mathrm{min}), \mathrm{lbf} / 100 f t^{2}=$ Max. dial reading at $3 \mathrm{rpm}$ 


\subsubsection{Determining Filtration}

In this study, the American Petroleum Institute (API) low pressure / low temperature fluid loss test is done for the filtration analysis which uses the standard API filter press pressured to a differential of 100 psi. [24]

The OFITE low pressure filter press is used in this study which helps to determine filtration and wall cake-building properties of drilling fluids. The filter press design features a cell body to hold the mud sample, a pressure inlet, and a base cap with screen and filter paper. Overview of OFITE low pressure filter press can be seen in Figure 4.5. To obtain coherent results, one thickness of the proper 9-cm filter paper has to be used. In this study, Whatman No. 50 Filter Paper is used. [28]

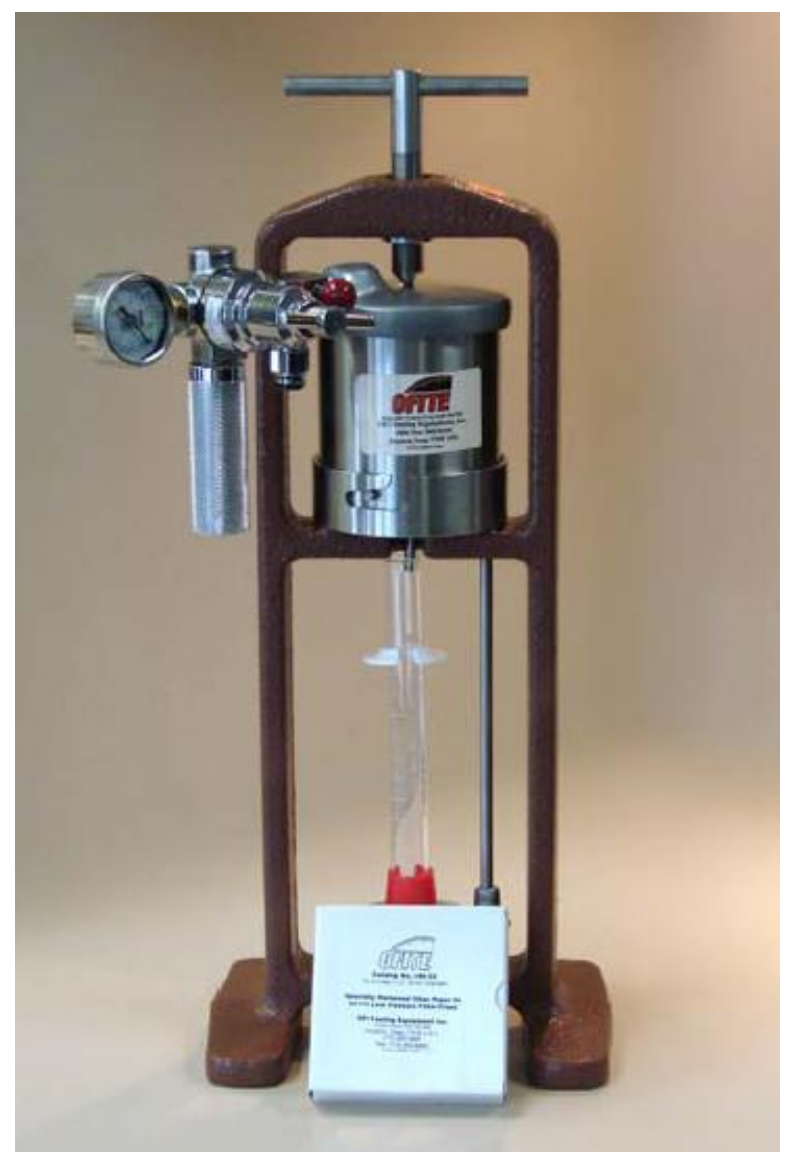

Figure 4.5: Overview of OFITE Low Pressure Filter Press ${ }^{[28]}$ 
Procedure for determining filtration can be observed step by step below [26]:

1. Collect the mud sample.

2. Assemble the cell with the filter paper in place.

3. Pour the sample into the cell to within $1 / 2$ inch $(13 \mathrm{~mm})$ from the top.

4. Set the cell into the frame; place and tighten the top on the cell.

5. Place a dry, graduated cylinder under the drain tube.

6. Close the relief valve and adjust the regulator so a pressure of $100 \pm 5 \mathrm{psi}(690 \pm$ $35 \mathrm{kPa}$ ) is applied in 30 seconds or less.

7. Maintain the pressure at $100 \pm 5 \mathrm{psi}(690 \pm 35 \mathrm{kPa})$ for 30 minutes.

8. Shut off the flow through the pressure regulator and open the relief valve carefully.

9. Report the volume of filtrate in the graduated cylinder to the nearest $\mathrm{mL}$.

10. Release the pressure, verify that all pressure has been relieved, and remove the cell from the frame.

11. Disassemble the cell and discard the mud.

\subsubsection{Determining Foam Forming Potential}

High foam forming potential and high half-life of the foam can be one of the negative effects on drilling fluid systems that we do not desire. Chandler Model 7000 Constant Speed Mixer is used for measuring the foam forming potential, overview of this mixer is shown in Figure 4.6. 


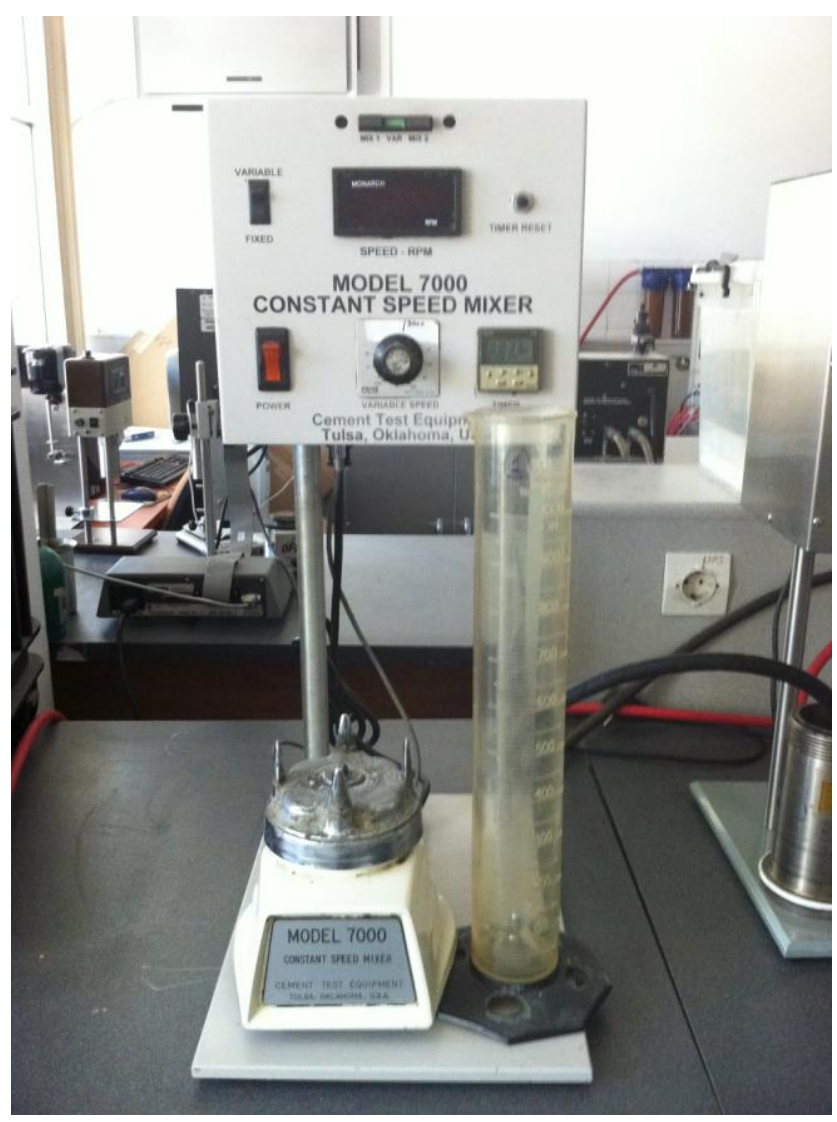

Figure 4.6: Overview of Chandler Model 7000 Constant Speed Mixer

Procedure for determining the half-life of the foam is defined below:

1. Measure $200 \mathrm{ml}$ of mud into a scaled mixing vessel.

2. Fit up the mixing vessel in Chandler Model 7000 Constant Speed Mixer.

3. Run the mixer at $9000 \mathrm{rpm}$ for 1 minute.

4. Record the highest volume of the foam reached, after mixing.

5. Record the time that $100 \mathrm{ml}$ of liquid builds up, as the half-life of foam. 


\section{CHAPTER 5}

\section{RESULTS AND DISCUSSION}

To obtain accurate results, experiments should be conducted according to the procedures of lubricity test, physical analysis and chemical analysis described in Chapter 4. Repeatability of the tests can be proved by comparing the results in Table A-19 and and Table A.2 in APPENDIX A.

\subsection{Lubricity Performance Analysis}

For lubricity performance analysis, OFITE Lubricity Tester is used to calculate the coefficient of friction (COF) values.

For the analysis, three different types of commercial chemical lubricants; fatty acid and glycerid based, triglycerid and vegetable oil based and polypropylene glycol based, diesel oil, and crude oil, consisting different API gravity, paraffin and asphaltene values, are used and added to a water-based lignosulfonate mud. Name of the samples for the lubricants that are used in this study, are tabulated in Table 5.1. 
Table 5.7: Properties and Sample Names of the Lubricants

\begin{tabular}{|c|c|}
\hline Sample Name & Properties \\
\hline LUBE-1 & Fatty Acid and Glycerids \\
\hline LUBE-2 & Triglycerid and Vegetable Oil \\
\hline LUBE-3 & Polypropylene Glycol \\
\hline HEAVY OIL & 19.6 API \\
\hline LIGHT OIL & 29.6 API \\
\hline
\end{tabular}

\subsubsection{Lubricity Performance Analysis of Lubricants Added to the Water-Based Lignosulfonate Mud Alone}

First of all, lubricants are added to the base water-based lignosulfonate mud alone. Results of the lubricity tests for the lubricants added alone are below. Figure 5.1 shows the overall analysis of the lubricants added to the water-based lignosulfonate mud alone. It can be seen that LUBE-1 shows the highest lubricity performance, and followed by LUBE-2, LUBE-3, LIGHT OIL, HEAVY OIL and DIESEL. Detailed results can be seen in APPENDIX A. 


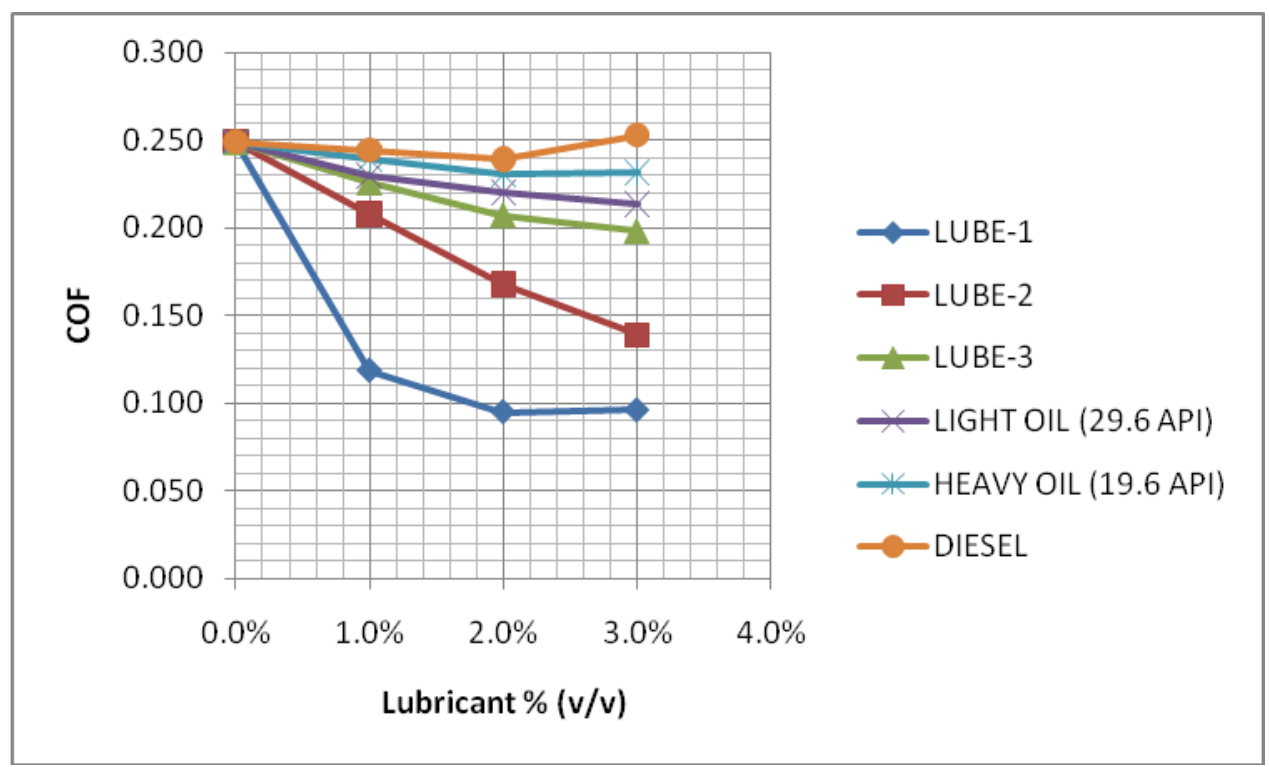

Figure 5.1: Overall Analysis of Lubricants Added to the Water-Based Lignosulfonate Mud Alone

\subsubsection{LUBE-1}

Fatty acid and glycerid based lubricant; LUBE-1, is added alone to the base water-based lignosulfonate drilling fluid that is designed for this study and coefficients of friction are calculated from the lubricity test performed with OFITE Lubricity Tester. LUBE-1 is added to the base mud; $1 \%, 2 \%$ and $3 \%$ by volume. Percentages above $3 \%$ are not tested as it is not recommended by the supplier and not cost effective. Figure 5.2 represents the coefficient of frictions of LUBE-1 added to the water-based lignosulfonate mud. It can be observed that increasing the LUBE-1 content makes a positive effect on fluids lubricity up to $2 \%$ and lubricity begins to decrease after exceeding $2 \%$ by volume. Therefore, adding LUBE-1 higher than $2 \%$, is insignificant. Detailed results are shown in Table A.1 in APPENDIX A. 


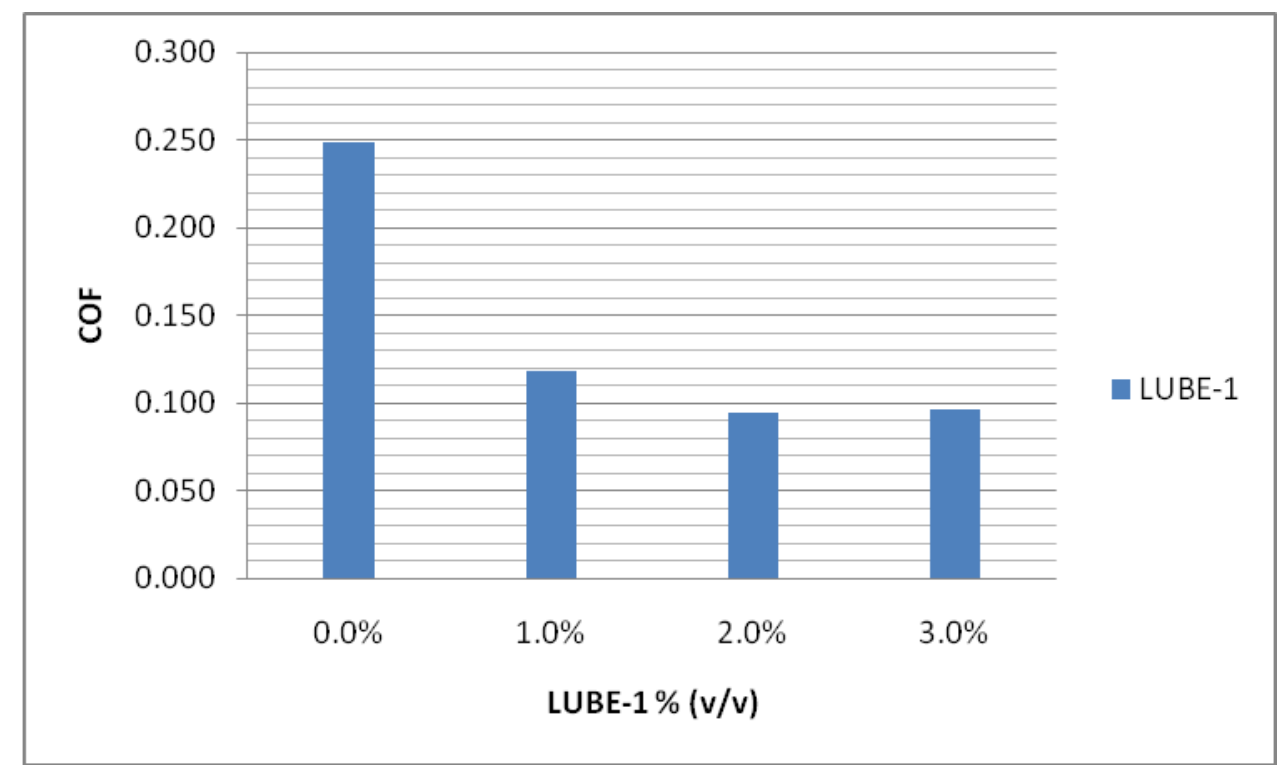

Figure 5.2: Coefficient of Frictions of LUBE-1 Added to the Water-Based Lignosulfonate Mud

\subsubsection{LUBE-2}

Triglycerid and vegetable oil based lubricant; LUBE-2, is added alone to the base water-based lignosulfonate drilling fluid that is designed for this study and coefficients of friction are calculated from the lubricity test performed with OFITE Lubricity Tester. LUBE-2 is added to the base mud; $1 \%, 2 \%$ and $3 \%$ by volume. Percentages above $3 \%$ are not tested as it is not recommended by the supplier and not cost effective. Figure 5.3 represents the coefficient of frictions of LUBE-2 added to the water-based lignosulfonate mud. It can be observed that increasing the LUBE-2 content makes a positive effect on fluids lubricity up to $3 \%$. Detailed results are shown in Table A.2 in APPENDIX A. 


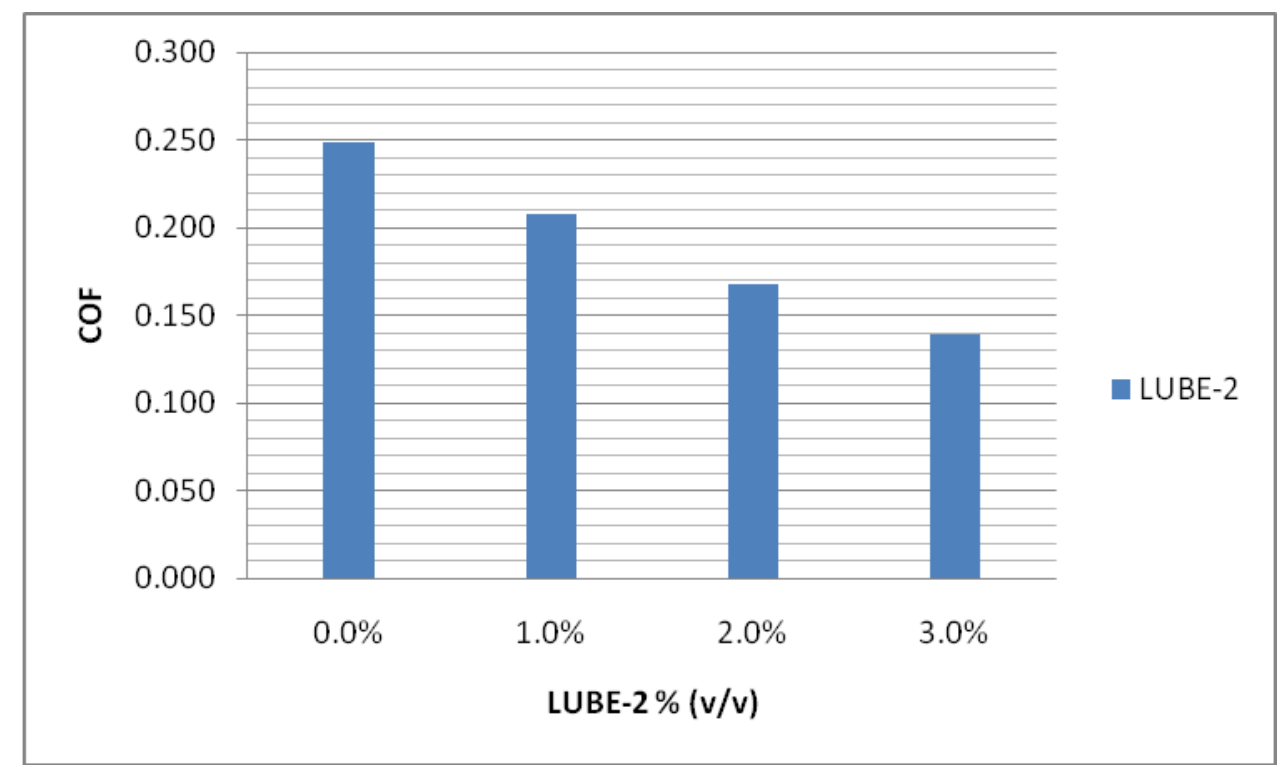

Figure 5.3: Coefficient of Frictions of LUBE-2 Added to the Water-Based Lignosulfonate Mud

\subsubsection{LUBE-3}

Polypropylene glycol based lubricant; LUBE-3, is added alone to the base water-based lignosulfonate drilling fluid that is designed for this study and coefficients of friction are calculated from the lubricity test performed with OFITE Lubricity Tester. LUBE-3 is added to the base mud; $1 \%, 2 \%$ and $3 \%$ by volume. Percentages above $3 \%$ are not tested as it is not recommended by the supplier and not cost effective. Figure 5.4 represents the coefficient of frictions of LUBE-3 added to the water-based lignosulfonate mud. It can be observed that increasing the LUBE-3 content makes a positive effect on fluids lubricity up to $3 \%$. However, rate of increasing lubricity begins to decrease after exceeding $2 \%$ by volume. Therefore, adding LUBE-3 higher than $2 \%$, may not be cost effective. Detailed results are shown in Table A.3 in APPENDIX A. 


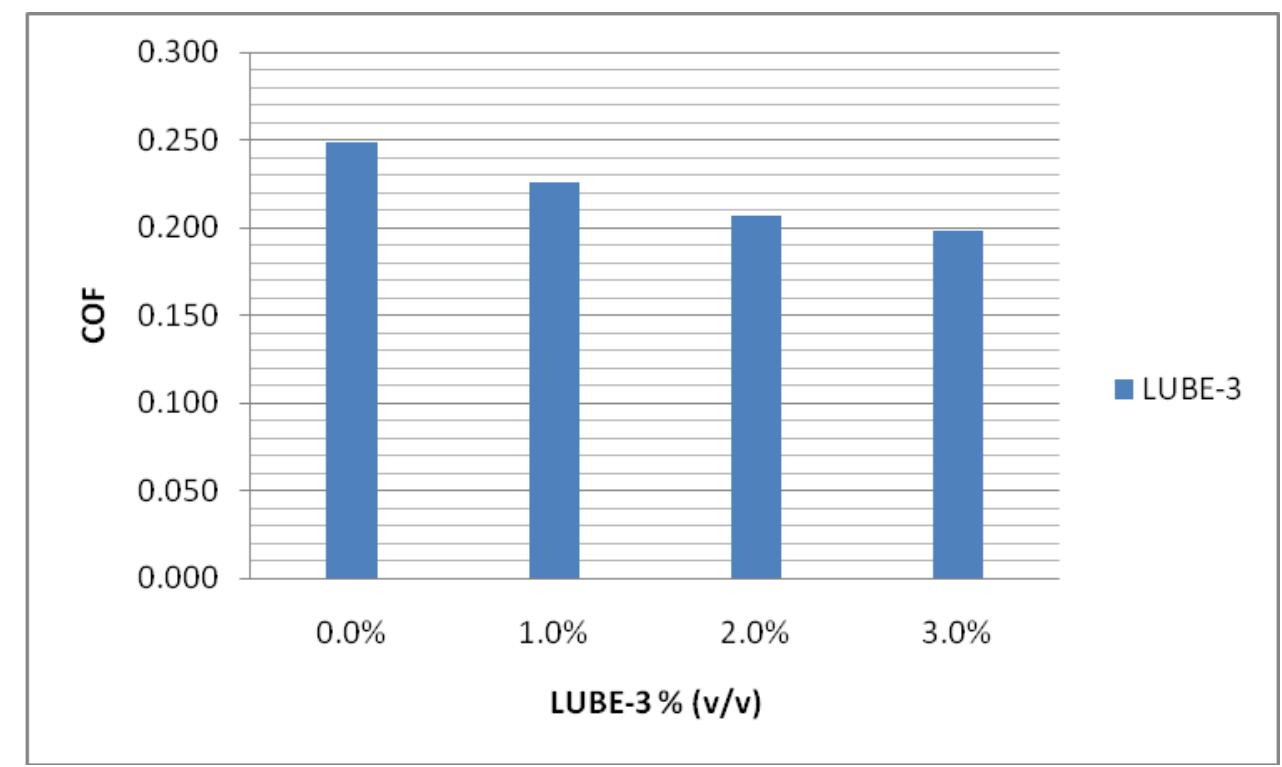

Figure 5.4: Coefficient of Frictions of LUBE-3 Added to the Water-Based Lignosulfonate Mud

\subsubsection{HEAVY OIL}

19.6 API gravity sample HEAVY OIL, is added alone to the base water-based lignosulfonate drilling fluid that is designed for this study and coefficients of friction are calculated from the lubricity test performed with OFITE Lubricity Tester. HEAVY OIL is added to the base mud; $1 \%, 2 \%$ and $3 \%$ by volume. Figure 5.5 represents the coefficient of frictions of HEAVY OIL added to the water-based lignosulfonate mud. It can be observed that increasing the HEAVY OIL content seems to make a positive effect on fluids lubricity up to $2 \%$ but the lubricity performance and decreasing ratio of the coefficient of friction is very low and lubricity begins to decrease after exceeding $2 \%$ by volume. Therefore, adding HEAVY OIL to the water-based lignosulfonate mud at any percentage can be considered as insignificant. Detailed results are shown in Table A.5 in APPENDIX A. 


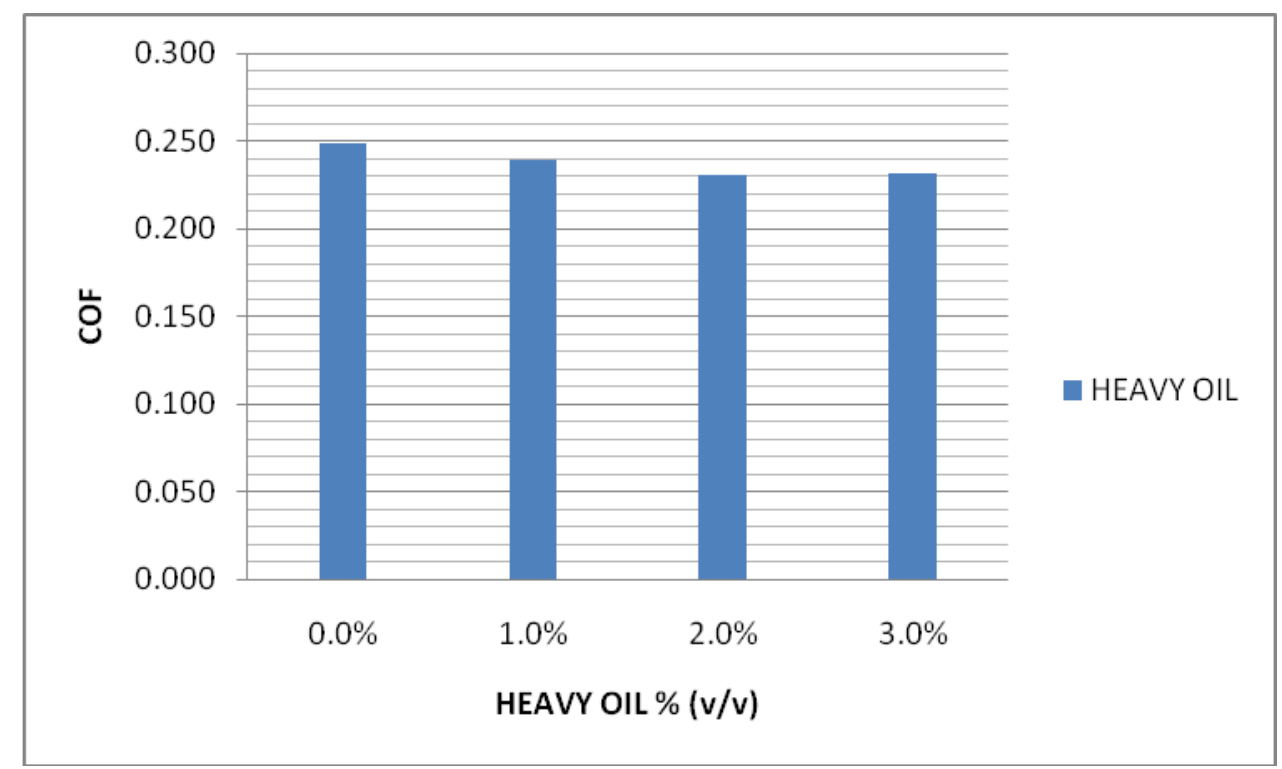

Figure 5.5: Coefficient of Frictions of HEAVY OIL Added to the Water-Based Lignosulfonate Mud

\subsubsection{LIGHT OIL}

29.6 API gravity sample LIGHT OIL, is added alone to the base water-based lignosulfonate drilling fluid that is designed for this study and coefficients of friction are calculated from the lubricity test performed with OFITE Lubricity Tester. LIGHT OIL is added to the base mud; up to $5 \%$ by volume. Figure 5.6 represents the coefficient of frictions of LIGHT OIL added to the water-based lignosulfonate mud. It can be observed that increasing the LIGHT OIL content seems to make a positive effect on fluids lubricity up to $3 \%$ and lubricity begins to decrease after exceeding $3 \%$ by volume. Therefore, adding LIGHT OIL to the water-based lignosulfonate mud, over 3\% by volume is insignificant. Detailed results are shown in Table A.4 in APPENDIX A. 


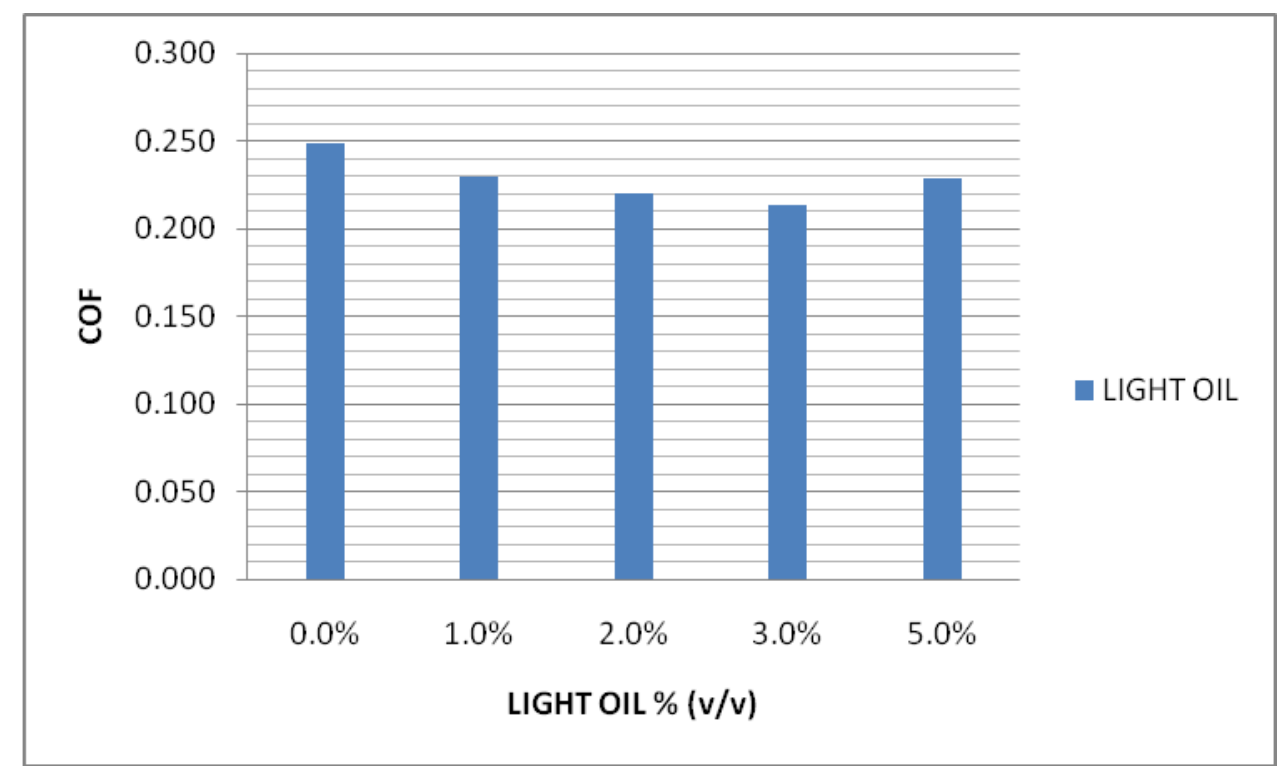

Figure 5.6: Coefficient of Frictions of LIGHT OIL Added to the Water-Based Lignosulfonate Mud

\subsubsection{DIESEL}

DIESEL, as a lubricant, is added alone, to the base water-based lignosulfonate drilling fluid that is designed for this study and coefficients of friction are calculated from the lubricity test performed with OFITE Lubricity Tester. DIESEL is added to the base mud; $1 \%, 2 \%$ and $3 \%$ by volume. Figure 5.7 represents the coefficient of frictions of DIESEL added to the water-based lignosulfonate mud. It can be observed that increasing the DIESEL content seems to make a very small positive effect on fluids lubricity up to $2 \%$ but the lubricity performance is very low and lubricity begins to decrease after exceeding $2 \%$ by volume. Lubricity performance of DIESEL at $3 \%$ by volume, is even worse than than the base mud lubricity. Therefore, adding DIESEL to the water-based lignosulfonate mud at any percentage can be considered as insignificant. Detailed results are shown in Table A.6 in APPENDIX A. 


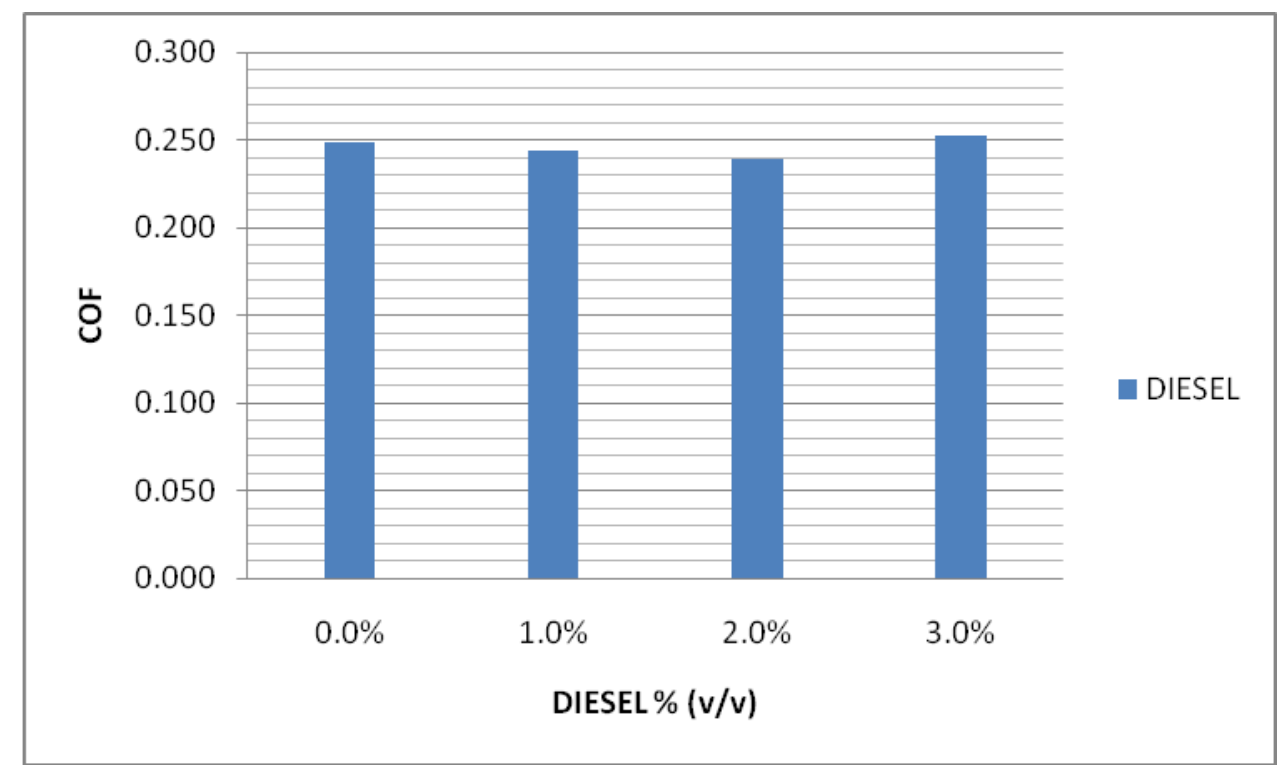

Figure 5.7: Coefficient of Frictions of DIESEL Added to the Water-Based Lignosulfonate Mud

\subsubsection{Lubricity Performance Analysis of LUBE-1, LUBE-2 AND LUBE-3 Mixed with HEAVY OIL, LIGHT OIL and DIESEL, Added to the Water-Based Lignosulfonate Mud}

In this section, LUBE-1, LUBE-2 and LUBE-3 are mixed with HEAVY OIL, LIGHT OIL and DIESEL with different compositions and are added to the base water-based lignosulfonate mud. Results of the lubricity tests for these compositions are discussed below.

\subsubsection{LUBE-1 and DIESEL}

$1 \%$ LUBE-1 is mixed with $2 \%$ DIESEL and added to the water-based lignosulfonate mud to see the effect of DIESEL in LUBE-1's lubricant performance and general lubricity. Figure 5.8 represents the coefficient of frictions of $1 \%$ LUBE-1, and $2 \%$ DIESEL mixed with $1 \%$ LUBE-1, that are added to the water-based lignosulfonate 
mud. It can be observed that the DIESEL content makes a negative effect on LUBE-1's performance and the fluids lubricity. Therefore, mixing DIESEL with LUBE-1 and adding to the water-based lignosulfonate mud is useless. Detailed results are tabulated in Table A.11 in APPENDIX A.

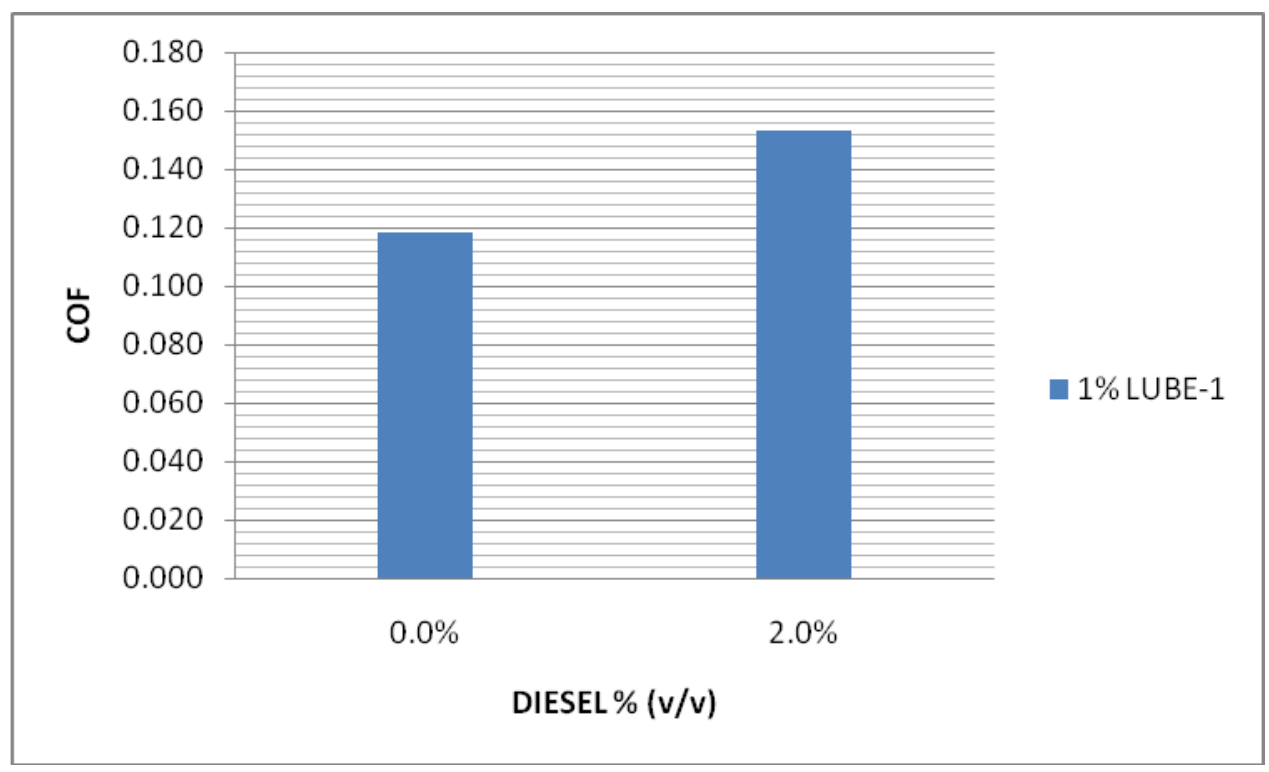

Figure 5.8: Coefficient of Frictions of 1\% LUBE-1, and 2\% DIESEL Mixed with 1\% LUBE-1 and Added to the Water-Based Lignosulfonate Mud

\subsubsection{LUBE-2 and DIESEL}

$1 \%$ LUBE-2 is mixed with $2 \%$ DIESEL and added to the water-based lignosulfonate mud to see the effect of DIESEL in LUBE-2's lubricant performance and general lubricity. Coefficient of frictions of 1\% LUBE-2, and 2\% DIESEL mixed with $1 \%$ LUBE-2, that are added to the water-based lignosulfonate mud is displayed in Figure 5.9. It can be observed that the DIESEL content makes a negative effect on LUBE-2's performance and the fluids lubricity. Therefore, mixing DIESEL with LUBE-2 and 
adding to the water-based lignosulfonate mud is useless. Detailed results are shown in Table A.11 in APPENDIX A.

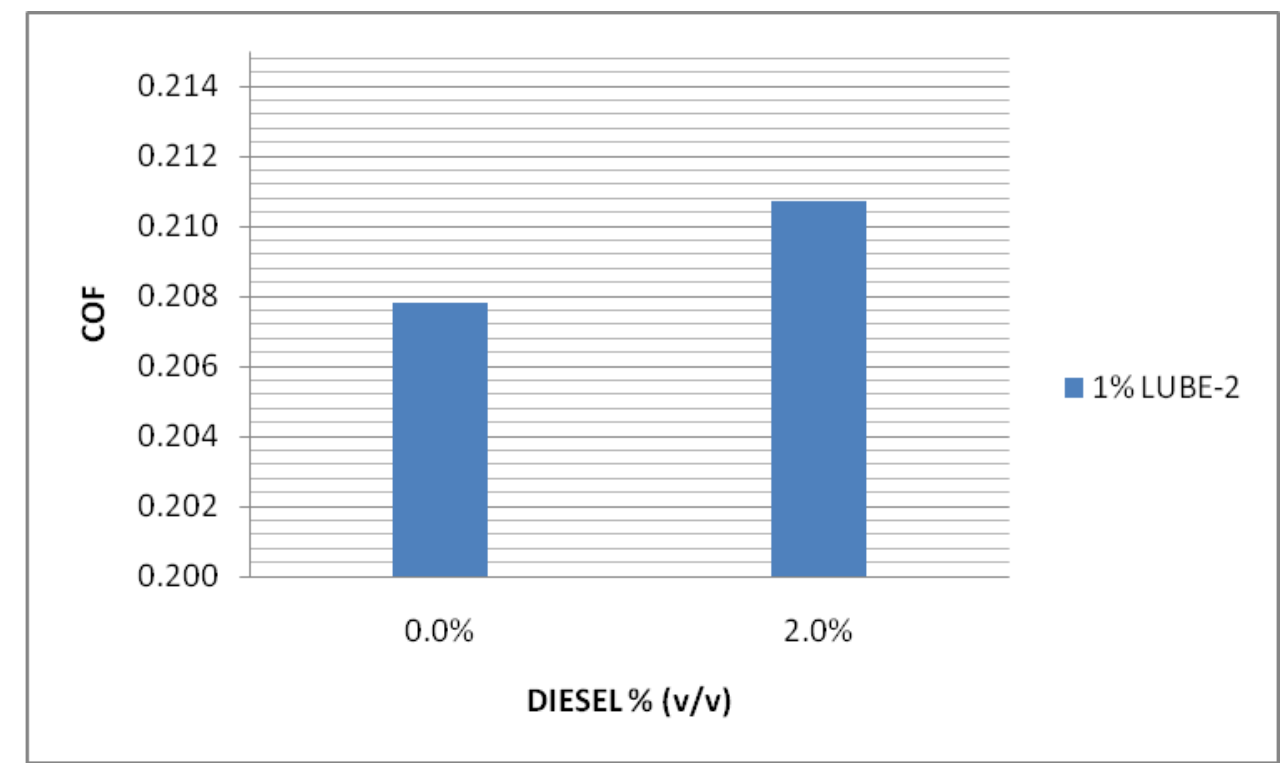

Figure 5.9: Coefficient of Frictions of 1\% LUBE-2, and 2\% DIESEL Mixed with 1\% LUBE-2 and Added to the Water-Based Lignosulfonate Mud

\subsubsection{LUBE-3 and DIESEL}

$1 \%$ LUBE-3 is mixed with $2 \%$ DIESEL and added to the water-based lignosulfonate mud to see the effect of DIESEL in LUBE-3's lubricant performance and general lubricity. Coefficient of frictions of $1 \%$ LUBE-3, and 2\% DIESEL mixed with $1 \%$ LUBE-3, that are added to the water-based lignosulfonate mud is shown in Figure 5.10. It can be observed that the DIESEL content makes a negative effect on LUBE-3's performance and the fluids lubricity. Therefore, mixing DIESEL with LUBE-3 and adding to the water-based lignosulfonate mud is insignificant. Detailed results are demonstrated in Table A.11 in APPENDIX A. 


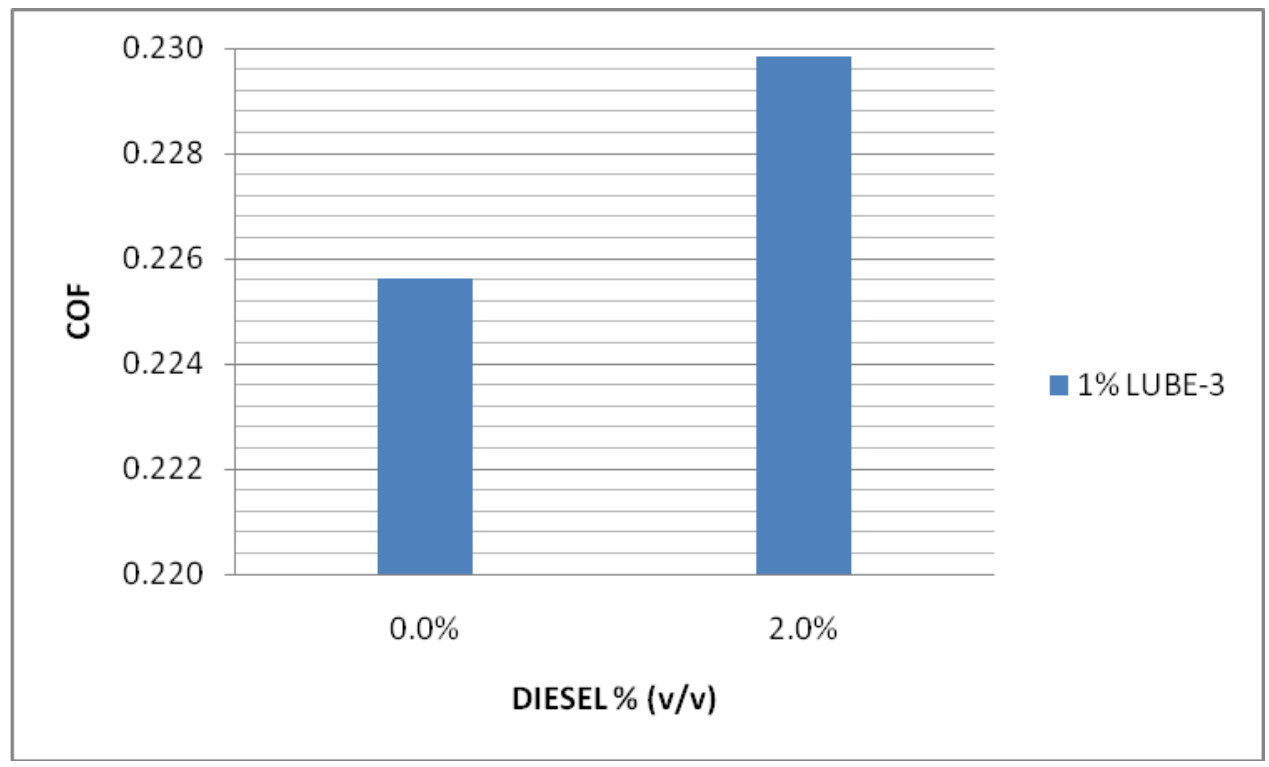

Figure 5.10: Coefficient of Frictions of 1\% LUBE-3, and 2\% DIESEL Mixed with 1\% LUBE-3 and Added to the Water-Based Lignosulfonate Mud

Figure 5.11 shows the overall analysis of 1\% LUBE-1, LUBE-2 and LUBE-3 mixed with DIESEL and added to the fluid. DIESEL's negative effect on lubricity can clearly be observed in this figure. 


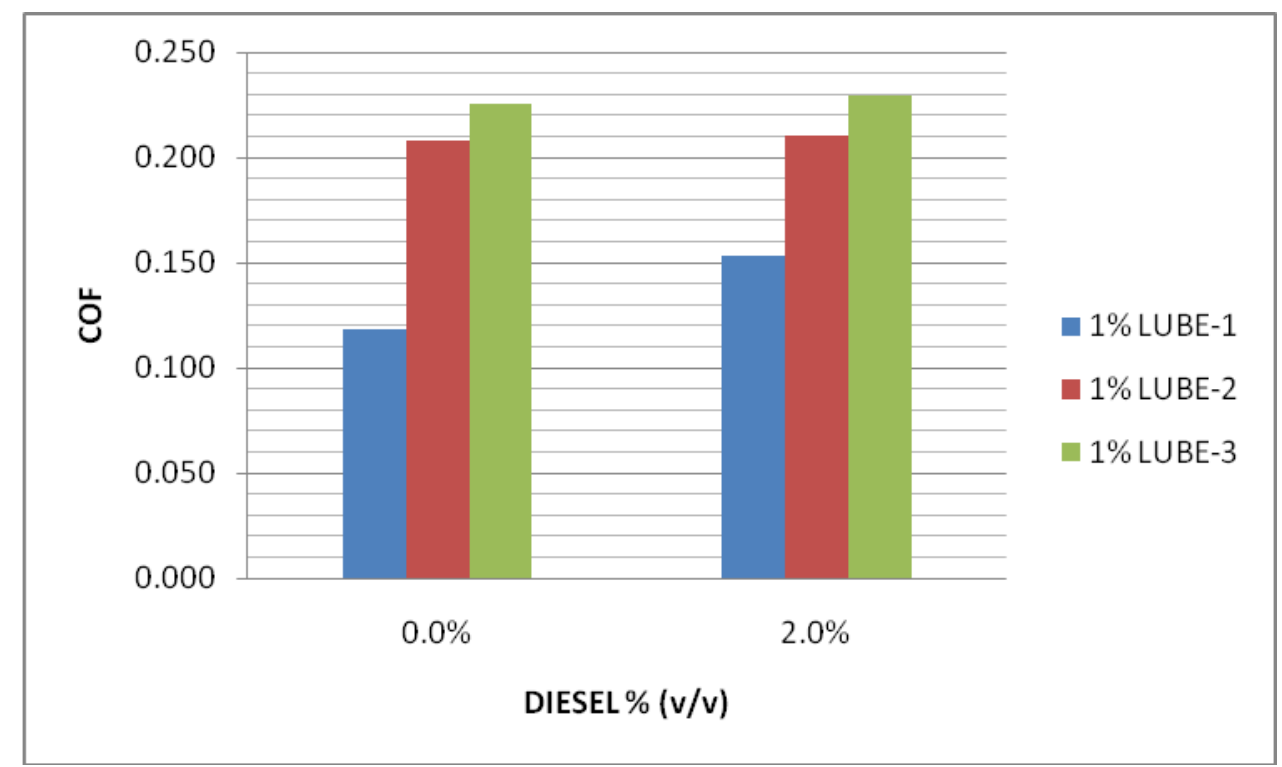

Figure 5.11: Overall Analysis of 1\% LUBE-1, LUBE-2 and LUBE-3 mixed with DIESEL and Added to the Water-Based Lignosulfonate Mud

\subsubsection{LUBE-1 and HEAVY OIL}

$1 \%$ LUBE-1 is mixed with $2 \%$ HEAVY OIL and added to the water-based lignosulfonate mud to see the effect of HEAVY OIL in LUBE-1's lubricant performance and general lubricity. Coefficient of frictions of $1 \%$ LUBE-1, and $2 \%$ HEAVY OIL mixed with 1\% LUBE-1, that are added to the water-based lignosulfonate mud is displayed in Figure 5.12. It can be observed that the HEAVY OIL content makes a negative effect on LUBE-1's performance and the fluids lubricity. Therefore, mixing HEAVY OIL with LUBE-1 and adding to the water-based lignosulfonate mud is insignificant. Detailed results are shown in Table A.10 in APPENDIX A. 


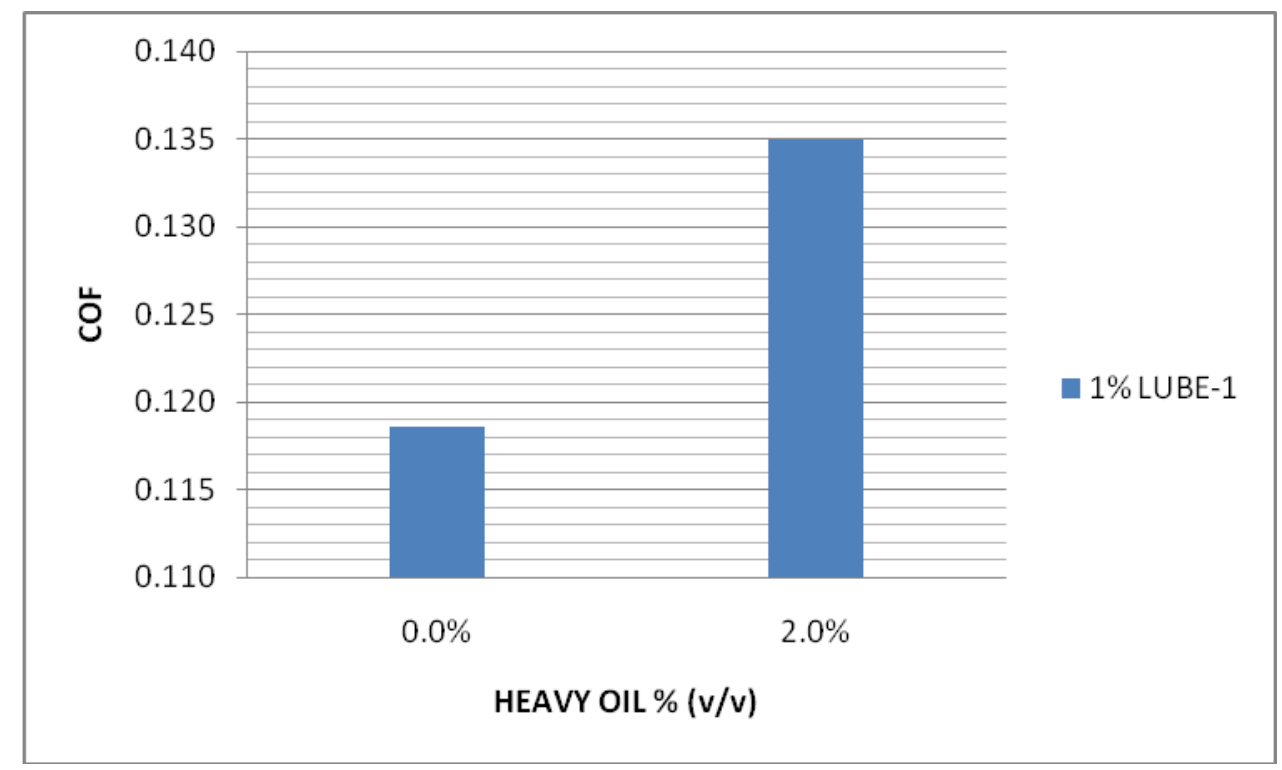

Figure 5.12: Coefficient of Frictions of 1\% LUBE-1, and 2\% HEAVY OIL Mixed with 1\% LUBE-1 and Added to the Water-Based Lignosulfonate Mud

\subsubsection{LUBE-2 and HEAVY OIL}

$1 \%$ LUBE-2 is mixed with $2 \%$ HEAVY OIL and added to the water-based lignosulfonate mud to see the effect of HEAVY OIL in LUBE-2's lubricant performance and general lubricity. Figure 5.13 represents the coefficient of frictions of $1 \%$ LUBE-2, and 2\% HEAVY OIL mixed with $1 \%$ LUBE-2, that are added to the water-based lignosulfonate mud. It can be observed that the HEAVY OIL content makes a negative effect on LUBE-2's performance and the fluids lubricity. Therefore, mixing HEAVY OIL with LUBE-2 and adding to the water-based lignosulfonate mud is useless. Detailed results are demonstrated in Table A.10 in APPENDIX A. 


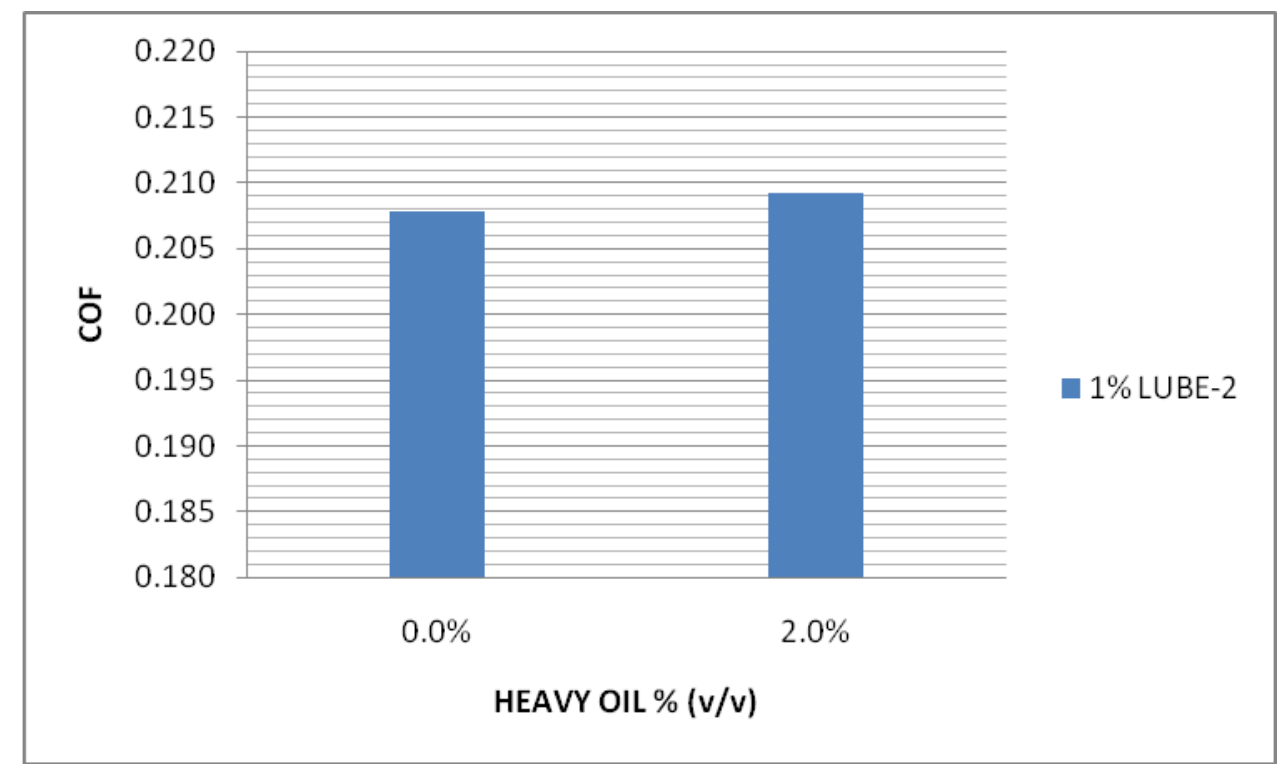

Figure 5.13: Coefficient of Frictions of 1\% LUBE-2, and 2\% HEAVY OIL Mixed with 1\% LUBE-2 and Added to the Water-Based Lignosulfonate Mud

\subsubsection{LUBE-3 and HEAVY OIL}

$1 \%$ LUBE-3 is mixed with $2 \%$ HEAVY OIL and added to the water-based lignosulfonate mud to see the effect of HEAVY OIL in LUBE-3's lubricant performance and general lubricity. Figure 5.14 shows the coefficient of frictions of $1 \%$ LUBE-3, and 2\% HEAVY OIL mixed with $1 \%$ LUBE-3, that are added to the waterbased lignosulfonate mud. It can be observed that the HEAVY OIL content makes a small positive effect on LUBE-3's performance and the fluids lubricity. However, it does not seem to be as lubricious as it has to be and it is not cost effective. Therefore, mixing HEAVY OIL with LUBE-3 and adding to the water-based lignosulfonate mud can be considered as insignificant. Detailed results are tabulated in Table A.10 in APPENDIX A. 


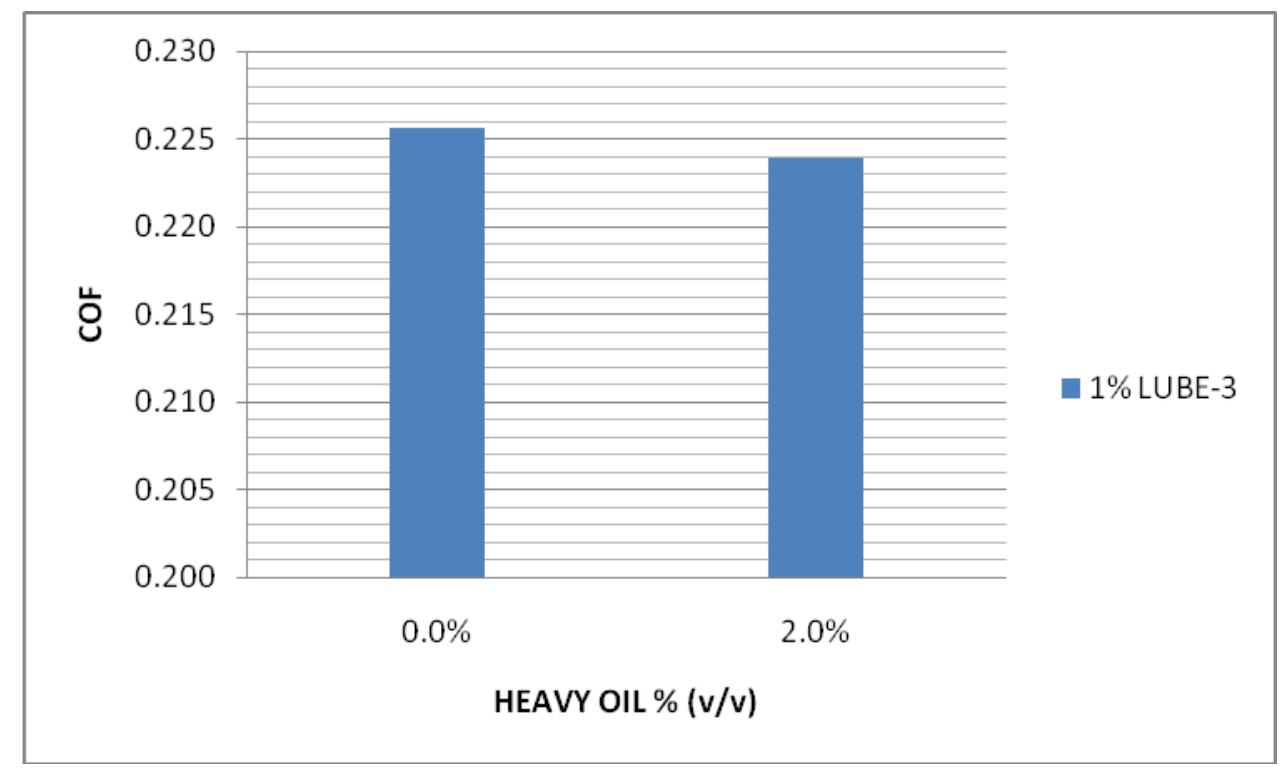

Figure 5.14: Coefficient of Frictions of 1\% LUBE-3, and 2\% HEAVY OIL Mixed with 1\% LUBE-3 and Added to the Water-Based Lignosulfonate Mud

In Figure 5.15, overall analysis of 1\% LUBE-1, LUBE-2 and LUBE-3 mixed with HEAVY OIL can be observed. HEAVY OIL's insignificant effect on lubricity can clearly be observed in this figure. 


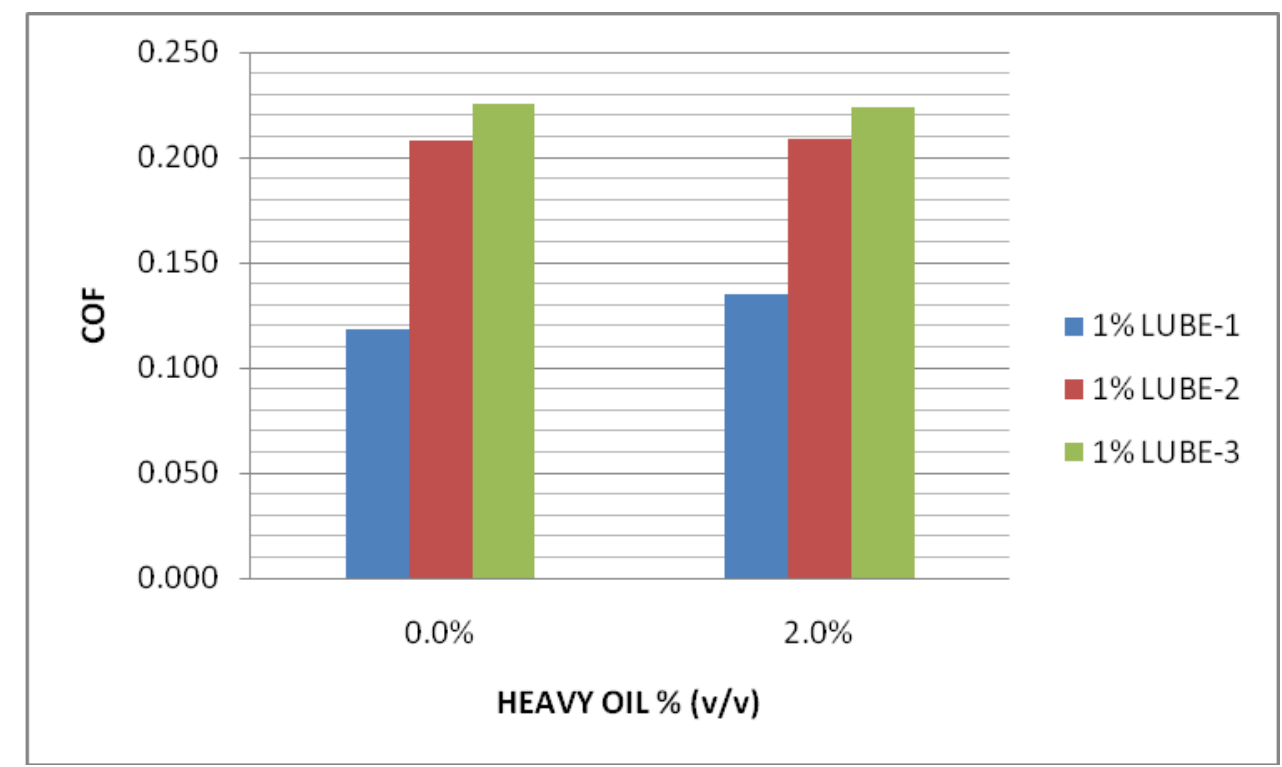

Figure 5.15: Overall Analysis of 1\% LUBE-1, LUBE-2 and LUBE-3 mixed with HEAVY OIL and Added to the Water-Based Lignosulfonate Mud

\subsubsection{LUBE-1 and LIGHT OIL}

Firstly, $1 \%$ LUBE-1 is mixed with $1 \%, 2 \%$ and $3 \%$ of LIGHT OIL by volume and added to the water-based lignosulfonate mud to see the effect of LIGHT OIL in LUBE1 's lubricant performance and general lubricity. Percentages over 3\% of LIGHT OIL are not considered, because it has a negative effect over $3 \%$ by volume. (See Figure 5.6) Figure 5.16 illustrates the coefficient of frictions of 1\% LUBE-1, and 1\%, $2 \%$ and $3 \%$ LIGHT OIL mixed with $1 \%$ LUBE-1, that are added to the water-based lignosulfonate drilling fluid. It can be seen that the LIGHT OIL content makes positive effect on $1 \%$ LUBE-1's performance up to 3\% LIGHT OIL by volume. Detailed results are shown in Table A.7 in APPENDIX A. 


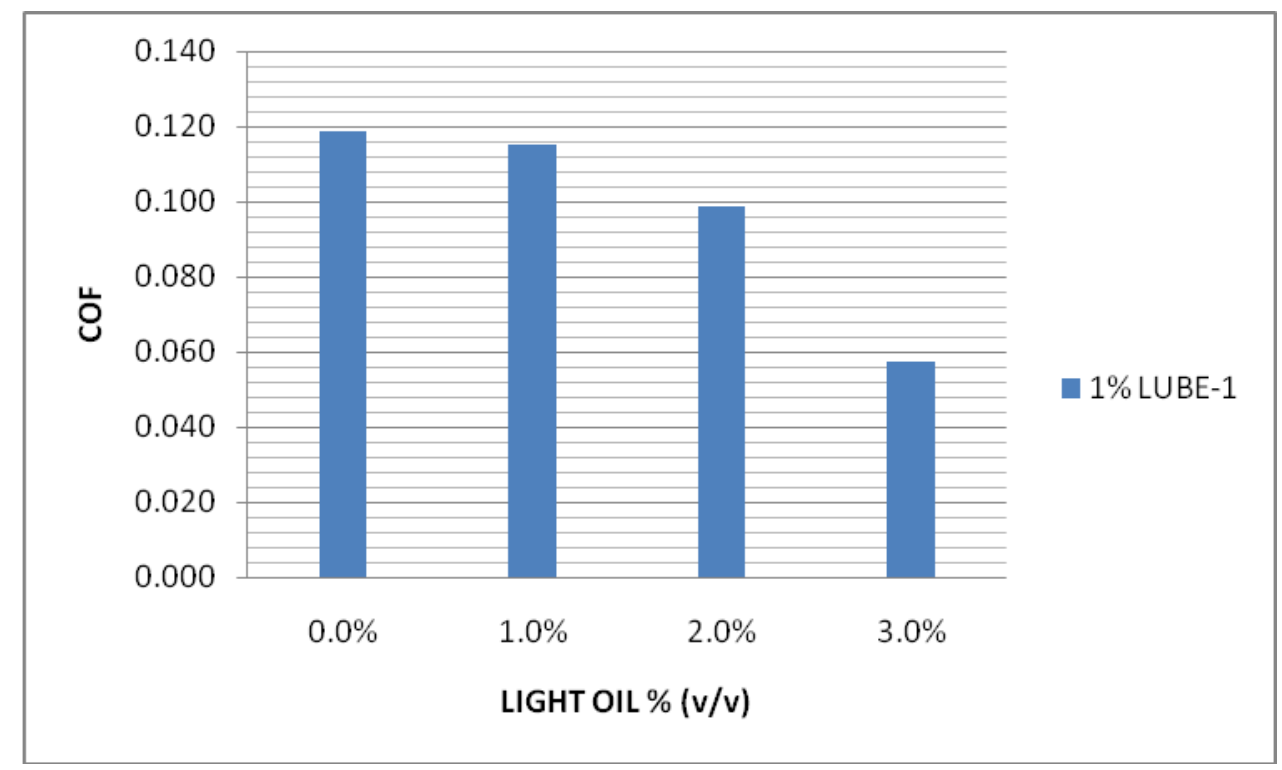

Figure 5.16: Coefficient of Frictions of 1\% LUBE-1, and 1\%, 2\% and 3\% LIGHT OIL Mixed with 1\% LUBE-1 and Added to the Water-Based Lignosulfonate Mud

Next, $2 \%$ LUBE-1 is mixed with $1 \%, 2 \%$ and $3 \%$ of LIGHT OIL by volume and added to the water-based lignosulfonate mud to see the effect of LIGHT OIL in LUBE-1's lubricant performance and general lubricity. Coefficient of frictions of $2 \%$ LUBE-1, and $1 \%, 2 \%$ and $3 \%$ LIGHT OIL mixed with $2 \%$ LUBE-1, that are added to the water-based lignosulfonate mud, is displayed in Figure 5.17. It can be observed that the LIGHT OIL content makes positive effect on $2 \%$ LUBE-1's performance up to $2 \%$ LIGHT OIL by volume. 3\% LIGHT OIL content makes a negative effect on mud lubricity. Therefore, mixing 2\% LUBE-1 with percentages exceeding $2 \%$ LIGHT OIL, is insignificant for the lubricity performance. Detailed results are demonstrated in Table A.7 in APPENDIX A. 


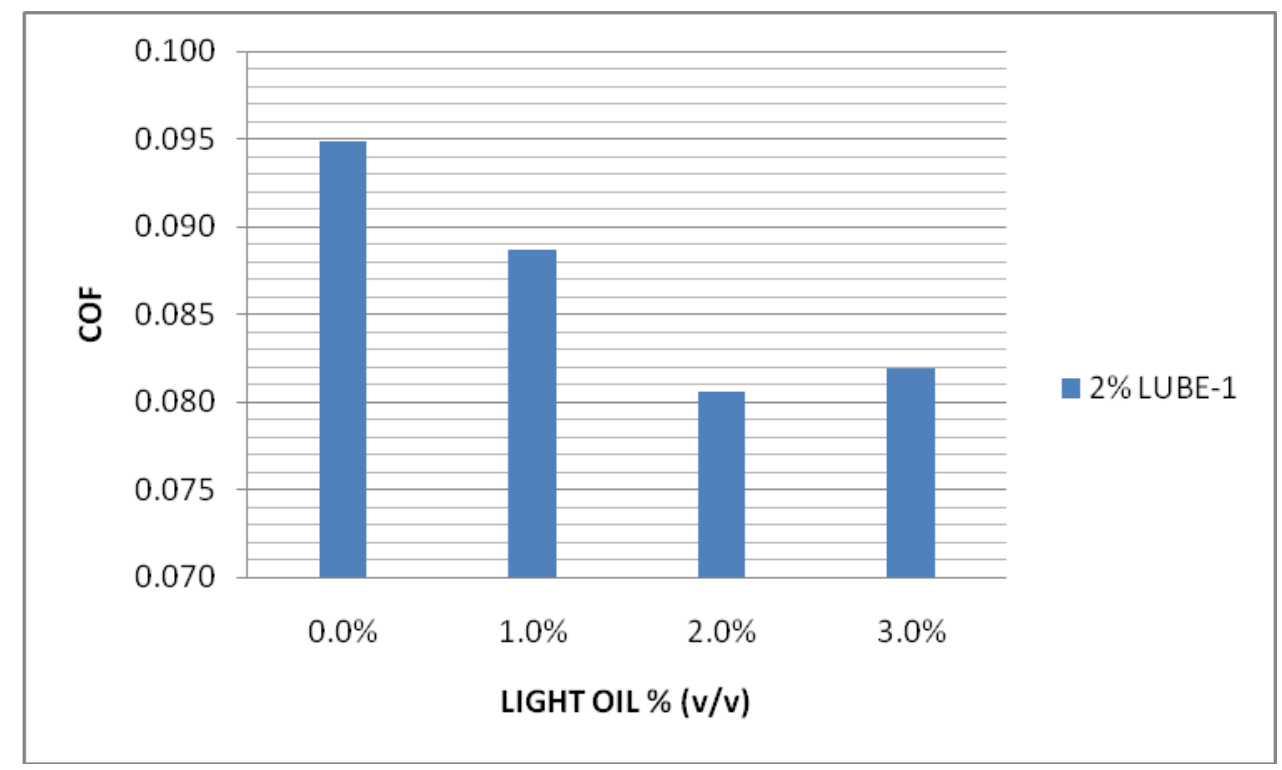

Figure 5.17: Coefficient of Frictions of 2\% LUBE-1, and 1\%, 2\% and 3\% LIGHT OIL Mixed with 2\% LUBE-1 and Added to the Water-Based Lignosulfonate Mud

\subsubsection{LUBE-2 and LIGHT OIL}

Firstly, $1 \%$ LUBE-2 is mixed with $1 \%, 2 \%$ and $3 \%$ of LIGHT OIL by volume and added to the water-based lignosulfonate mud to see the effect of LIGHT OIL in LUBE2's lubricant performance and general lubricity. Over 3\% of LIGHT OIL is not considered, as it has a negative effect over 3\% by volume as seen in Figure 5.6. Figure 5.18 shows the coefficient of frictions of $1 \%$ LUBE-2, and 1\%, $2 \%$ and $3 \%$ LIGHT OIL mixed with $1 \%$ LUBE-2, that are added to the water-based lignosulfonate mud. It can be observed that the LIGHT OIL content makes positive effect on 1\% LUBE-2's performance up to $3 \%$ LIGHT OIL by volume. It can be noted that LIGHT OIL has more impact on $1 \%$ LUBE-2's performance, at $2 \%$ and $3 \%$ by volume. Detailed results are shown in Table A.8 in APPENDIX A. 


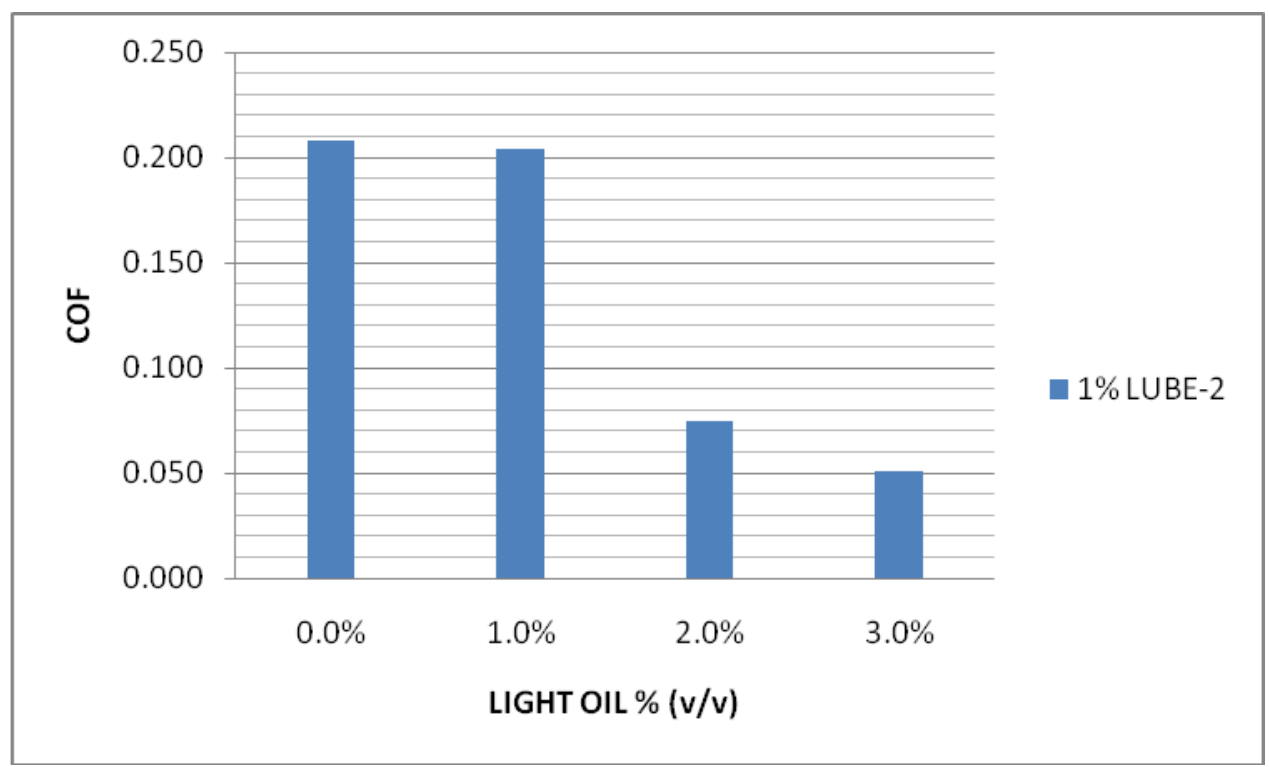

Figure 5.18: Coefficient of Frictions of 1\% LUBE-2, and 1\%, 2\% and 3\% LIGHT OIL Mixed with 1\% LUBE-2 and Added to the Water-Based Lignosulfonate Mud

Next, $2 \%$ LUBE-2 is mixed with $1 \%, 2 \%$ and $3 \%$ of LIGHT OIL by volume and added to the water-based lignosulfonate mud to see the effect of LIGHT OIL in LUBE-2's lubricant performance and general lubricity. Coefficient of frictions of $2 \%$ LUBE-2, and $1 \%, 2 \%$ and $3 \%$ LIGHT OIL mixed with $2 \%$ LUBE-2, that are added to the water-based lignosulfonate mud, is displayed in Figure 5.19. It can be observed that the LIGHT OIL content makes positive impact on 2\% LUBE-2's performance up to $3 \%$ LIGHT OIL by volume. Detailed results are shown in Table A.8 in APPENDIX A. 


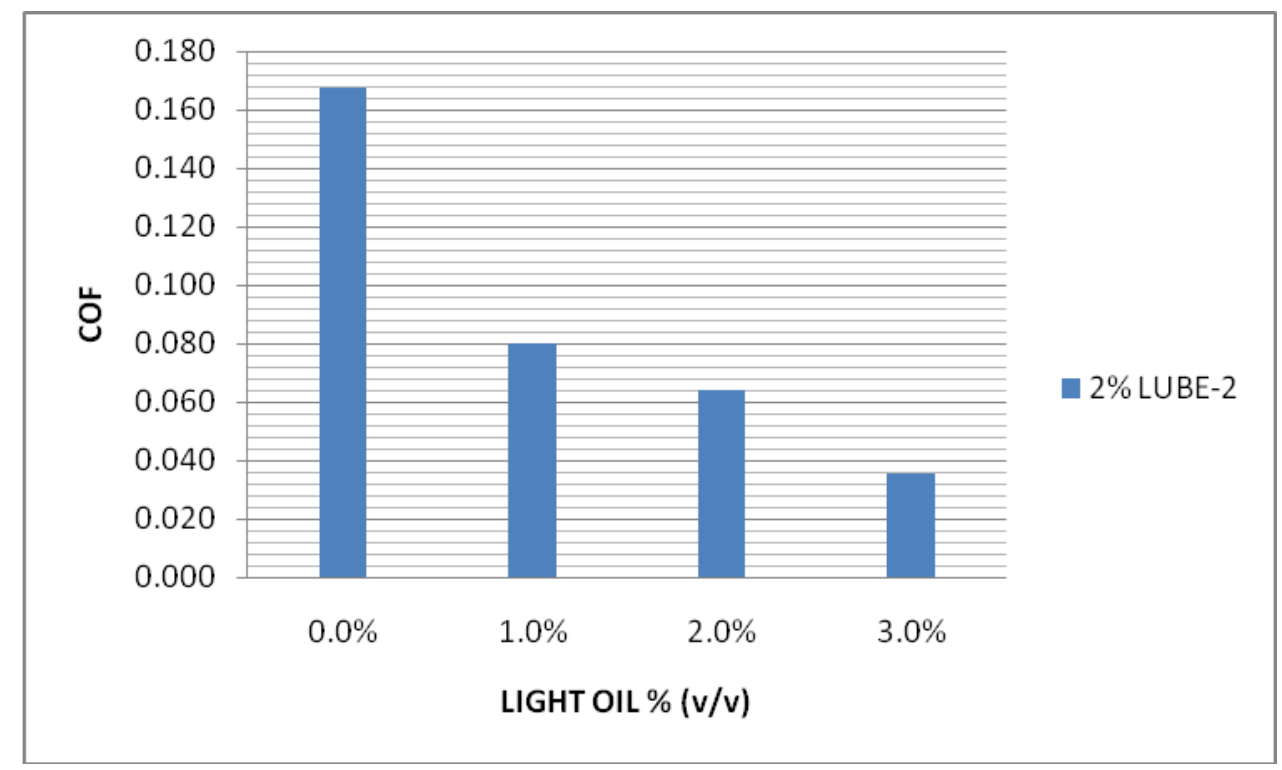

Figure 5.19: Coefficient of Frictions of 2\% LUBE-2, and 1\%, $2 \%$ and 3\% LIGHT OIL Mixed with 2\% LUBE-2 and Added to the Water-Based Lignosulfonate Mud

\subsubsection{LUBE-3 and LIGHT OIL}

Firstly, $1 \%$ LUBE-3 is mixed with $1 \%, 2 \%$ and $3 \%$ of LIGHT OIL by volume and added to the water-based lignosulfonate mud to see the effect of LIGHT OIL in LUBE3's lubricant performance and general lubricity. Over 3\% of LIGHT OIL is not tested, as it can be observed in Figure 5.6 that it has a negative effect on lubricity over $3 \%$ by volume. Figure 5.20 shows the coefficient of frictions of 1\% LUBE-3, and 1\%, 2\% and $3 \%$ LIGHT OIL mixed with $1 \%$ LUBE-3, that are added to the water-based lignosulfonate mud. It can be observed that the LIGHT OIL content makes positive effect on $1 \%$ LUBE-3's performance up to 3\% LIGHT OIL by volume. LIGHT OIL's impact on mud lubricity increases at percentages of $2 \%$ and $3 \%$ by volume. Detailed results are shown in Table A.9 in APPENDIX A. 


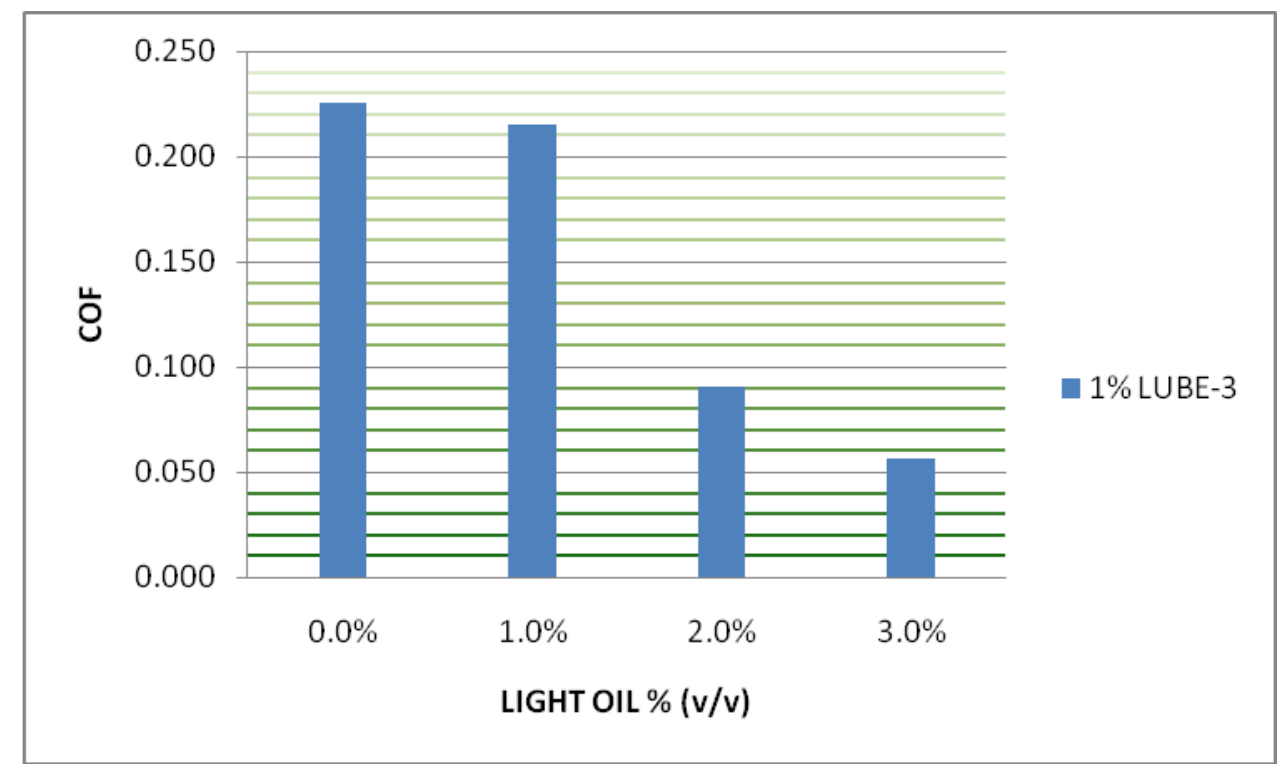

Figure 5.20: Coefficient of Frictions of 1\% LUBE-3, and 1\%, 2\% and 3\% LIGHT OIL Mixed with 1\% LUBE-3 and Added to the Water-Based Lignosulfonate Mud

Next, $2 \%$ LUBE-3 is mixed with $1 \%, 2 \%$ and $3 \%$ of LIGHT OIL by volume and added to the water-based lignosulfonate mud to see the effect of LIGHT OIL in LUBE-3's lubricant performance and general lubricity. Coefficient of frictions of $2 \%$ LUBE-3, and $1 \%, 2 \%$ and $3 \%$ LIGHT OIL mixed with $2 \%$ LUBE-3, that are added to the water-based lignosulfonate mud, is displayed in Figure 5.21. It can be observed that the LIGHT OIL content makes positive effect on $2 \%$ LUBE-3's performance up to $2 \%$ LIGHT OIL by volume. 3\% LIGHT OIL content makes a negative effect on mud lubricity. Therefore, mixing $2 \%$ LUBE-3 with percentages exceeding $2 \%$ LIGHT OIL by volume, is insignificant for the lubricity performance. Detailed results are shown in Table A.9 in APPENDIX A. 


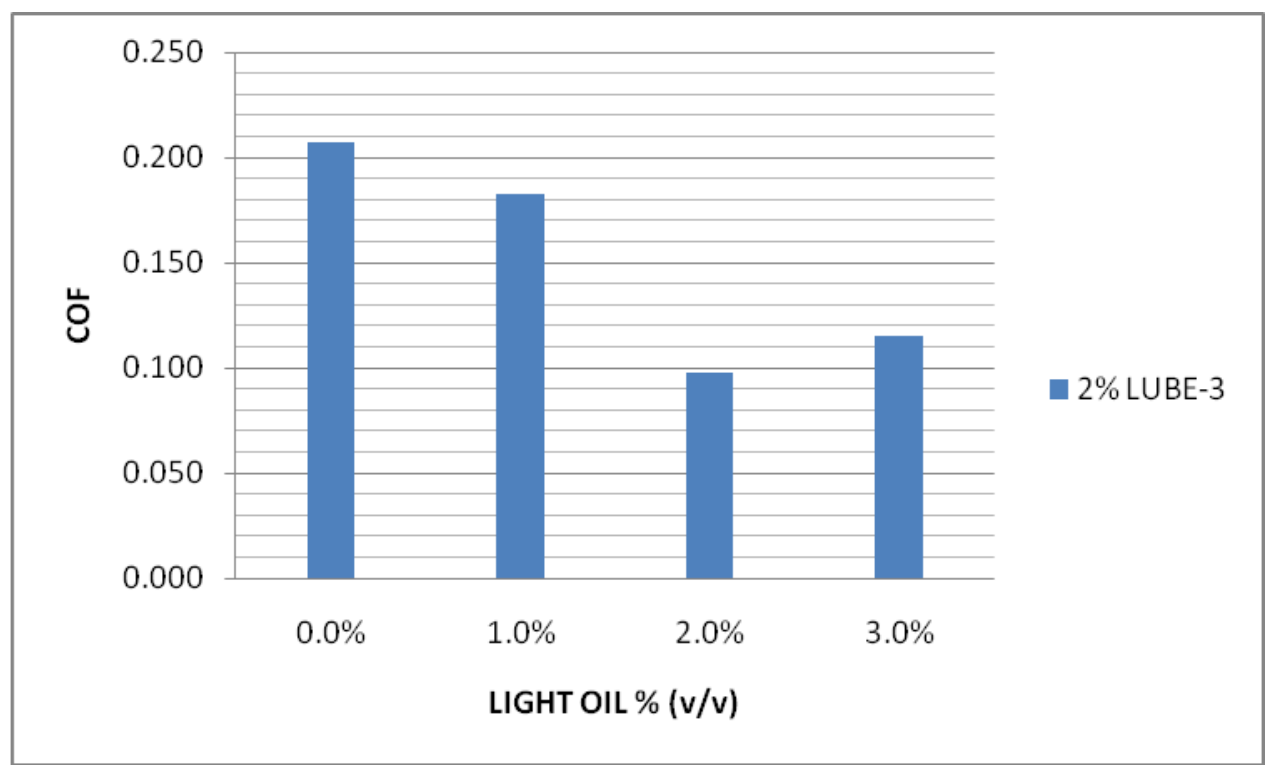

Figure 5.21: Coefficient of Frictions of 2\% LUBE-3, and 1\%, $2 \%$ and 3\% LIGHT OIL Mixed with 2\% LUBE-3 and Added to the Water-Based Lignosulfonate Mud

Figure 5.22 and 5.23 illustrates the overall coefficient of frictions of $1 \%$ and $2 \%$ LUBE1, LUBE-2 and LUBE-3 mixed with LIGHT OIL and added to the drilling fluid. It can be seen that $1 \%$ LUBE-1 mixed with 3\% LIGHT OIL, 2\% LUBE-2 mixed with 3\% LIGHT OIL, and 1\% LUBE-1 mixed with 3\% LIGHT OIL give the best lubricity performance. 


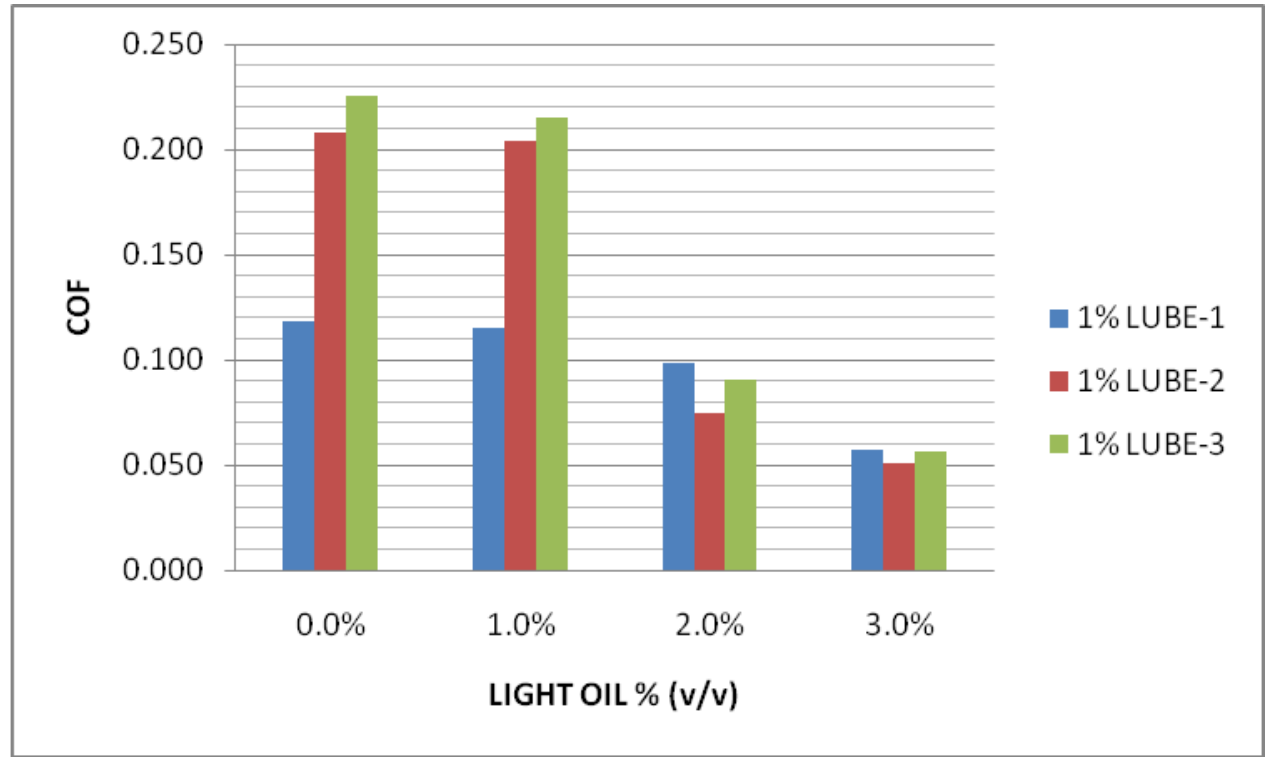

Figure 5.22: Overall Analysis of 1\% LUBE-1, LUBE-2 and LUBE-3 mixed with LIGHT OIL and Added to the Water-Based Lignosulfonate Mud

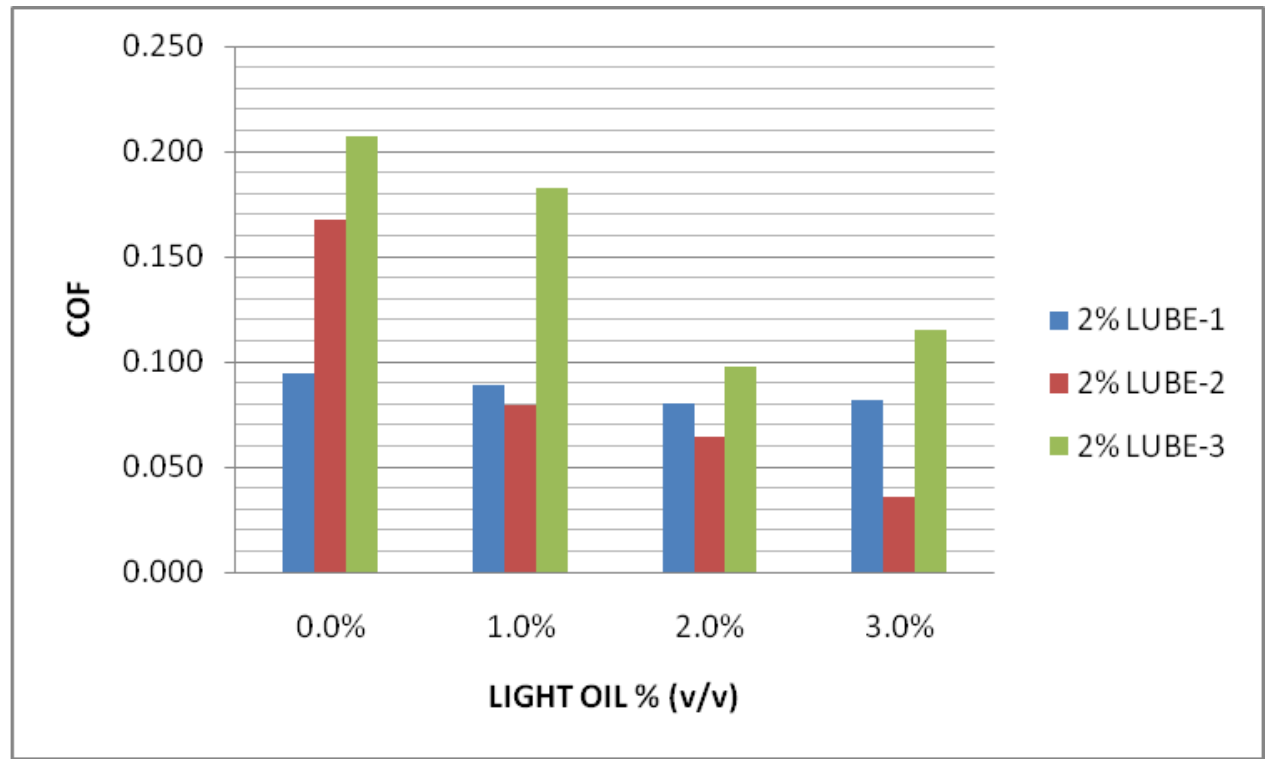

Figure 5.23: Overall Analysis of 2\% LUBE-1, LUBE-2 and LUBE-3 mixed with LIGHT OIL and Added to the Water-Based Lignosulfonate Mud 


\subsection{Analysis of Lubricants Effects on Mud Properties}

Physical analysis and chemical analysis of the drilling fluids are hold in order to see the effects of lubricants on mud properties. Detailed results are shown in APPENDIX A.

\subsubsection{Physical Analysis}

Physical analysis consists of rheological analysis, fluid loss analysis, cheesing/greasing and foam forming potential analysis of drilling fluids containing lubricants.

\subsubsection{Rheological Analysis}

In the rheological analysis section, plastic viscosity (PV), yield point (YP) and 10 sec/10 min gel strengths of the drilling fluids are tested and calculated using FANN Model 35SA Viscometer at $120^{\circ} \mathrm{F}$.

LUBE-1, LUBE-2, LUBE-3, LIGHT OIL, HEAVY OIL and DIESEL is added to the water-based lignosulfonate mud alone with percantages of $1 \%, 2 \%$ and $3 \%$ by volume. After the lubricity analysis of these samples, rheological analysis are made.

As seen in Figure 5.24, plastic viscosity analyses of the lubricants are hold. It can be observed from the figure that, HEAVY OIL and DIESEL have increasing plastic viscosities with increasing percentages. High plastic viscosities due to lubricant additions are undesirable for drilling fluids. LUBE-1, LUBE-2, LUBE-3 and LIGHT OIL have acceptable plastic viscosity values calculated from the viscosity experiments. 


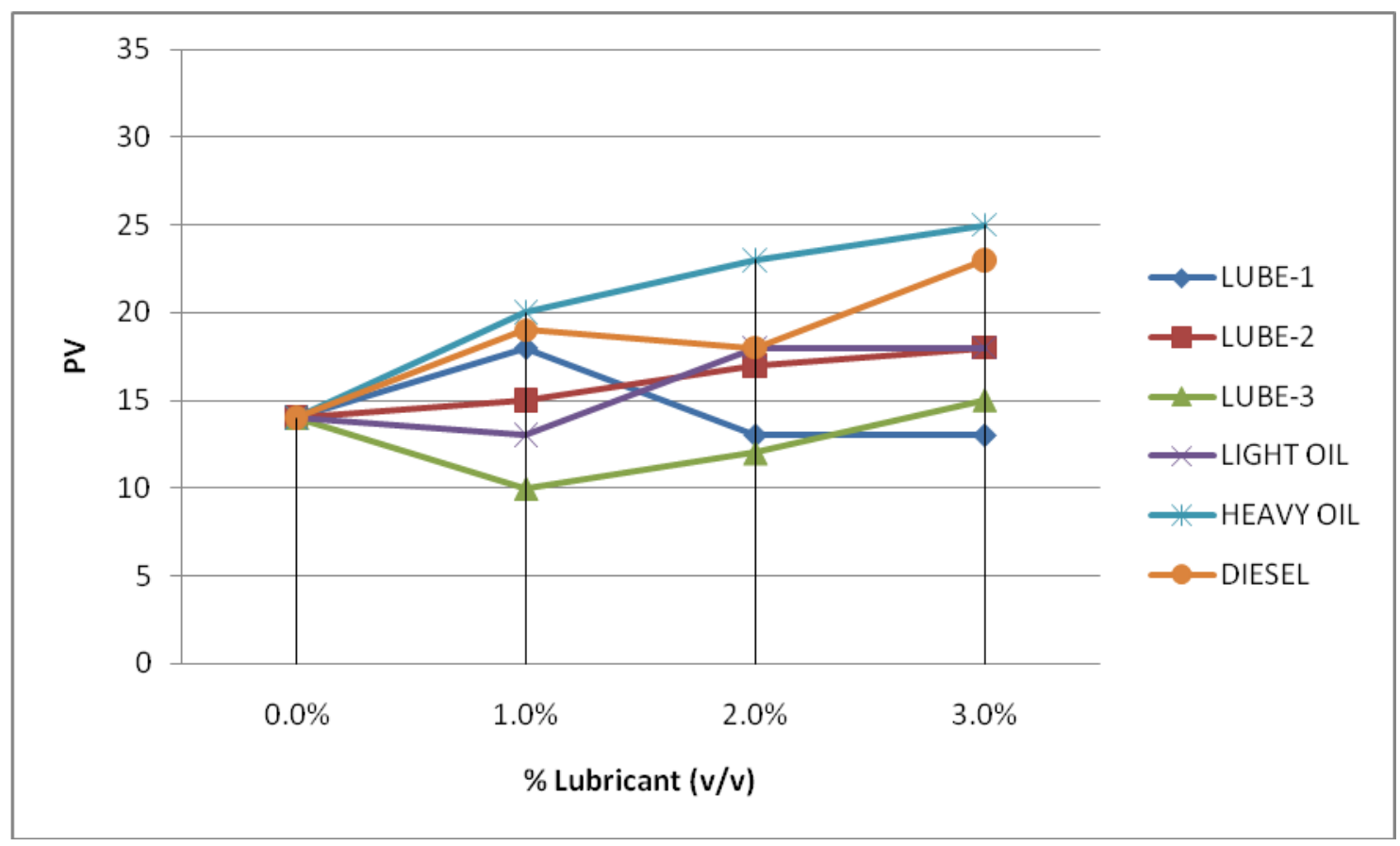

Figure 5.24: Plastic Viscosity Values of Lubricants Added to the Water-Based Lignosulfonate Mud

Plastic viscosity of compositions with LUBE-1, LUBE-2 and LUBE-3 mixed with HEAVY OIL, LIGHT OIL and DIESEL added to the base water-based lignosulfonate mud are calculated. It can be observed that, plastic viscosity (PV) values of samples are slightly proportional to the PV values of the mixtures with lubricants added alone, depending to the lubricant type and lubricant percentage.

Yield point analyses of the lubricants are displayed in Figure 5.25. It can be observed from the figure that, HEAVY OIL and DIESEL have highly increasing yield point values with increasing percentages. High yield point values due to lubricant additions are undesirable for drilling fluids. LUBE-1 has a slightly increasing yield points, however it can be considered as acceptable up to additions of $3 \%$ per volume. LUBE-2, LUBE-3 and LIGHT OIL have acceptable yield values calculated from rheological measurements. 


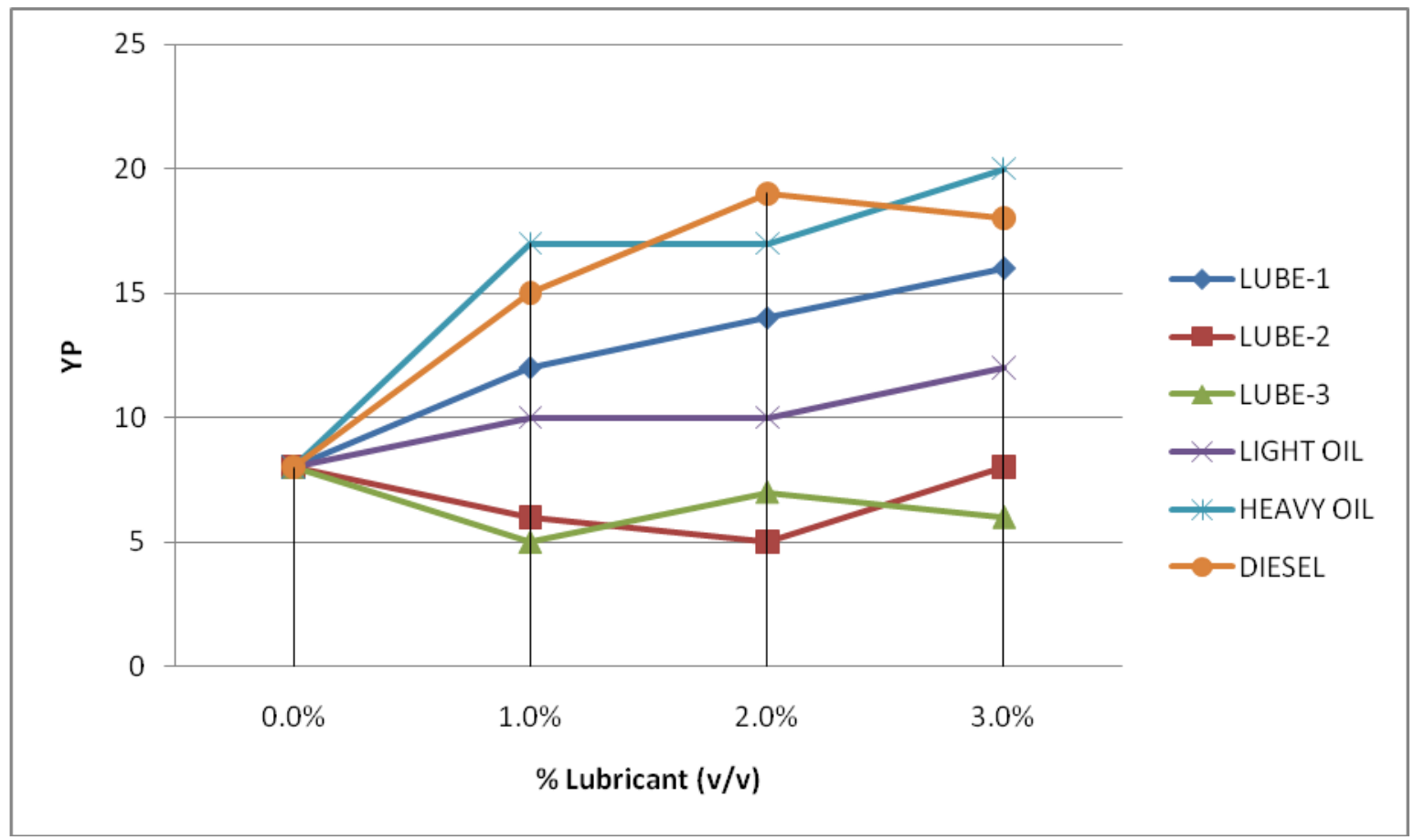

Figure 5.25: Yield Point Values of Lubricants Added to the Water-Based Lignosulfonate Mud

Yield point values of compositions with LUBE-1, LUBE-2 and LUBE-3 mixed with HEAVY OIL, LIGHT OIL and DIESEL added to the base water-based lignosulfonate mud are calculated. It can be observed that, yield point (YP) values of samples are slightly proportional to the YP values of the mixtures with lubricants added alone, depending to the lubricant type and lubricant percentage.

$10 \mathrm{sec} / 10$ min gel strengths of LUBE-1, LUBE-2, LUBE-3, LIGHT OIL, HEAVY OIL and DIESEL added alone and compositions with LUBE-1, LUBE-2 and LUBE-3 mixed with HEAVY OIL, LIGHT OIL and DIESEL to the water-based lignosulfonate mud, are in acceptable ranges for the drilling fluid system. 


\subsubsection{Fluid Loss Analysis}

In the fluid loss section, API low temperature fluid loss of the drilling fluids is tested using OFITE API Filter Press.

LUBE-1, LUBE-2, LUBE-3, LIGHT OIL, HEAVY OIL and DIESEL is added to the water-based lignosulfonate mud alone with percantages of $1 \%, 2 \%$ and $3 \%$ by volume and API fluid loss analysis are made.

As seen in Figure 5.26, API fluid loss analyses of the lubricants are hold. It can be observed from the figure that, LUBE-1, LIGHT OIL and HEAVY OIL have decreased the API fluid loss values with increasing percentages. Low API fluid loss values are always desirable for drilling fluids. LUBE-2, LUBE-3 and DIESEL do not have any negative effects and have acceptable API fluid loss values. 


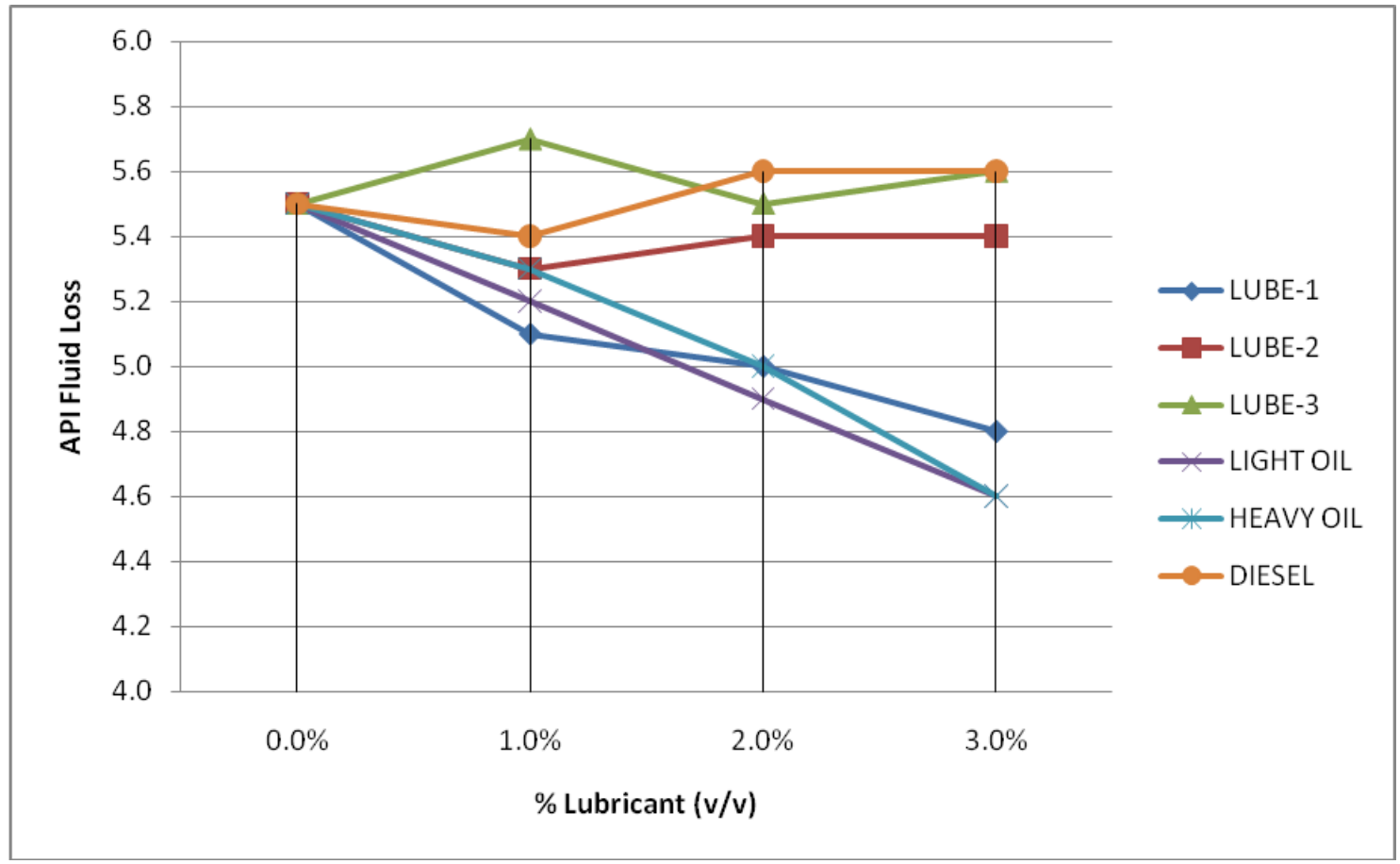

Figure 5.26: API Fluid Loss of Lubricants Added to the Water-Based Lignosulfonate Mud

API fluid loss values of compositions with LUBE-1, LUBE-2 and LUBE-3 mixed with HEAVY OIL, LIGHT OIL and DIESEL added to the base water-based lignosulfonate mud are measured. It can be observed that, API fluid loss values of samples are slightly proportional to the API fluid loss values of the mixtures with lubricants added alone, depending to the lubricant type and lubricant percentage.

\subsubsection{Cheesing/Greasing Analysis}

In the cheesing/greasing analysis section, persistent curd-like phase was appeared on the surface of some samples. This situation is not a desired case in drilling fluid systems. 
Cheesing appeared in all the mixtures that contain HEAVY OIL, DIESEL and LIGHT OIL that exceeds $\% 3$ by volume and in the mud that contains LUBE- 3 and LIGHT OIL. Example of a curd-like phase is shown in Figure 5.27.

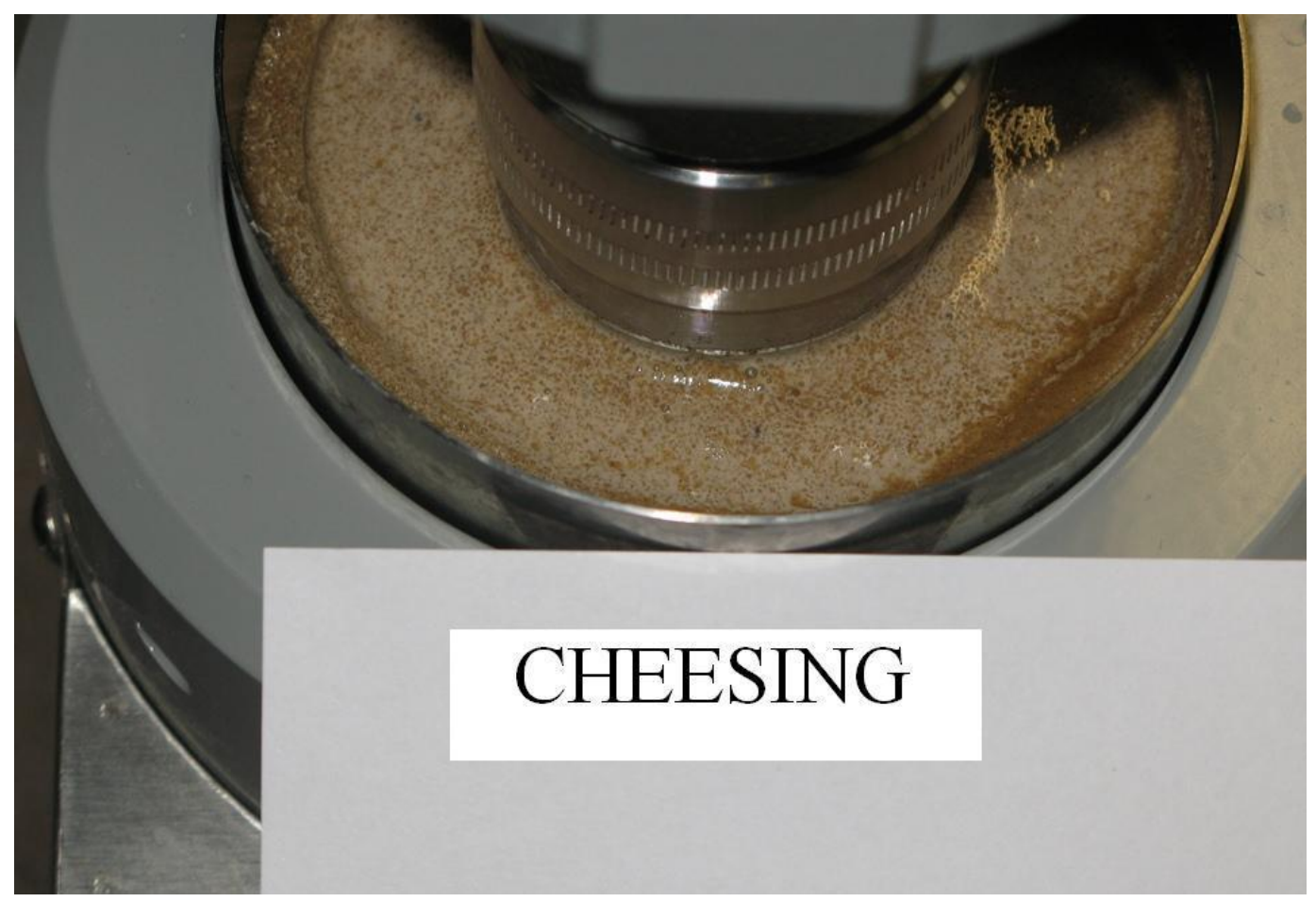

Figure 5.27: Example of a Curd-Like Phase on the Surface of Drilling Fluid

\subsubsection{Foam Forming Potential Analysis}

In the foam forming potential analysis section, half-life of the foam is calculated using Chandler Model 7000 Constant Speed Mixer. In drilling fluid systems, we do not desire high half-life of foam that is over 100 minutes.

None of the mixtures have significant foam forming potential, but mixtures containing LUBE-2. However, those foams have half-lives lower than 100 minutes. 


\subsubsection{Chemical Analysis}

Chemical analysis consists of $\mathrm{pH}$, chloride ion and calcium ion analysis of drilling fluids containing lubricants.

\subsubsection{1. pH Analysis}

In the $\mathrm{pH}$ analysis section, none of the mixtures have significant $\mathrm{pH}$ change with the addition of any lubricants as tabulated in Table A.1 to A.11 in APPENDIX A.

\subsubsection{Chloride Ion Analysis}

In the chloride ion analysis section, it can be observed in Table A.1 to A.11 in APPENDIX A that none of the mixtures have significant change in chloride ion content with the addition of any lubricants.

\subsubsection{Calcium Ion Analysis}

In the calcium ion analysis section, none of the mixtures have significant change in calcium ion content the addition of any lubricants as seen in Table A.1 to A.11 in APPENDIX A.

\subsection{Analysis of Influence of Mud Properties on Lubricity}

Influence of $\mathrm{pH}$, influence of calcium ion, influence of chloride ion and influence of mud weight on the drilling fluids lubricating properties are tested in this section. $2 \%$ LUBE-1, LUBE-2 and LUBE-3 is mixed separately with 1\% LIGHT OIL and added to the water-based lignosulfonate drilling fluid. Detailed results are shown in APPENDIX A. 


\subsubsection{Influence of $\mathrm{pH}$}

Influence of $\mathrm{pH}$ is tested with the addition of $1.5 \mathrm{ppb}$ of $\mathrm{NaOH}$ to the base drilling fluid. $1 \%$ LIGHT OIL and $2 \%$ commercial chemical lubricants are used as lubricious additives. Performance of lubricants and the fluids lubricity do not change with $\mathrm{pH}$ increasing up to 11.5. Detailed results are shown in Table A.13 in APPENDIX A.

\subsubsection{Influence of Calcium Ion}

Influence of calcium ion is tested with the addition of $1 \mathrm{ppb}$ of gypsum to the base drilling fluid. 1\% LIGHT OIL and $2 \%$ commercial chemical lubricants are used as lubricious additives. Performance of lubricants and the fluids lubricity do not change with calcium ion increasing up to $500 \mathrm{mg} / \mathrm{lt}$. Detailed results are shown in Table A.12 in APPENDIX A.

\subsubsection{Influence of Chloride Ion}

Influence of chloride ion is tested with the addition of $4 \mathrm{ppb}$ of $\mathrm{NaCl}$ to the base drilling fluid. $1 \%$ LIGHT OIL and $2 \%$ commercial chemical lubricants are used as lubricious additives. Performance of lubricants and the fluids lubricity are affected negatively by the chloride ion content increasing up to $10000 \mathrm{mg} / \mathrm{lt}$. Mud rheology is also affected negatively. Detailed results are shown in Table A.14 in APPENDIX A.

\subsubsection{Influence of Mud Weight}

Influence of mud weight is tested with the addition of $10,40,80,110,150 \mathrm{ppb}$ of barite to the base drilling fluid. 1\% LIGHT OIL and $2 \%$ commercial chemical lubricants are used as lubricious additives. Mud weights are in range of 68 cuft to 86 cuft. Increasing the mud weight alone, does not change the lubricity performance of the mud. However, increasing the mud weight with the additions of $1 \%$ LIGHT OIL and $2 \%$ commercial 
chemical lubricants, has a positive effect on lubricity rising with the barite content. Detailed results are shown in Table A.15, A.16, A.17 and A.18 in APPENDIX A.

Overall negative or positive effects of general properties of LUBE-1, LUBE-2, LUBE3, DIESEL, HEAVY OIL and LIGHT OIL added alone is tabulated in Table 5.2

Table 5.2: Overall Negative and Positive Effects of Lubricants

\begin{tabular}{|l|c|c|c|c|c|c|}
\cline { 2 - 7 } \multicolumn{1}{l|}{} & LUBE-1 & LUBE-2 & LUBE-3 & DIESEL & $\begin{array}{c}\text { HEAVY } \\
\text { OIL }\end{array}$ & $\begin{array}{c}\text { LIGHT } \\
\text { OIL }\end{array}$ \\
\hline Lubricity & + & + & + & - & - & + \\
\hline PV & + & + & + & - & - & + \\
\hline YP & - & + & + & - & - & + \\
\hline API Fluid Loss & + & + & + & + & + & + \\
\hline Cheesing & + & + & + & - & - & + \\
\hline $\begin{array}{l}\text { Foam Forming } \\
\text { Potential }\end{array}$ & + & + & + & + & + & + \\
\hline pH & + & + & + & + & + & + \\
\hline Chloride Ion & + & + & + & + & + & + \\
\hline Calcium Ion & + & + & + & + & + & + \\
\hline $\begin{array}{l}\text { Influence of pH } \\
\text { on lubricant }\end{array}$ & + & + & + & + & + & + \\
\hline $\begin{array}{l}\text { Influence of Cl } \\
\text { on lubricant }\end{array}$ & - & - & - & - & - & - \\
\hline $\begin{array}{l}\text { Influence of Ca } \\
\text { on lubricant }\end{array}$ & + & + & + & + & + & + \\
\hline
\end{tabular}




\section{CHAPTER 6}

\section{CONCLUSION}

In this study, performances of drilling fluid liquid lubricants are analyzed. Three different types of commercial chemical lubricants, which are fatty acid and glycerid based, triglycerid and vegetable oil based and polypropylene glycol based, diesel oil, and crude oil which consists of different API gravity, paraffin and asphaltene value samples are selected for the analysis and added to a water-based lignosulfonate mud. Also, lubricants effects on mud properties and influence of mud properties on lubricant performance are analyzed. The experiments are carried out in TPAO Research Center. The results are analyzed and the following conclusions can be drawn from the study:

- Highest lubricity performance is obtained from the mixtures of LIGHT OIL and chemical commercial lubricants added to the water-based lignosulfonate mud.

- $1 \%$ LUBE-1 and 3\% LIGHT OIL, 2\% LUBE-2 and 3\% LIGHT OIL, 1\% LUBE-3 and 3\% LIGHT OIL mixtures added to the water-based lignosulfonate mud are the most lubricious and cost effective compositions.

- LUBE-1, LUBE-2 and LUBE-3 increase the lubricity performance of the mud up to $3 \%$ by volume when used alone.

- LUBE-1 shows the highest lubricity performance when added alone to the mud. 
- HEAVY OIL and DIESEL have negative influence on drilling fluid's lubricity performance either used alone or with chemical commercial lubricants. Therefore, using HEAVY OIL and DIESEL in water-based lignosulfonate mud as a lubricant is useless.

- LIGHT OIL does not have sufficient lubricity performance when they are added alone in the water-based lignosulfonate mud.

- Lubricity performance of LIGHT OIL begins to decrease when added to the water-based lignosulfonate mud at exceeding $3 \%$ by volume. Therefore, using LIGHT OIL higher than $3 \%$ by volume is insignificant.

- HEAVY OIL and DIESEL increases the rheological properties of the drilling fluids which is an undesirable effect.

- LIGHT OIL, HEAVY OIL and LUBE-1 decrease the API fluid loss of the drilling fluids as a positive effect.

- As an undesirable effect of lubricants; cheesing/greasing appears in all the mixtures that contain HEAVY OIL, DIESEL and exceeding 3\% LIGHT OIL and in the mud that contains LUBE-3 and LIGHT OIL.

- None of the lubricants have significant foam forming potential problem.

- None of the lubricants have caused significant chemical mud properties problem including $\mathrm{pH}$, calcium ion content and chloride ion content.

- Influence of $\mathrm{pH}$ and calcium ion content do not cause problems on drilling fluid's lubricity performance. 
- High chloride ion content has a negative effect on fluids lubricity and rheological properties.

- Increasing the mud weight alone, does not change the lubricity performance of the mud.

- Increasing the mud weight with the additions of lubricants has a positive effect on lubricity. (1\% LIGHT OIL and 2\% LUBE-1/LUBE-2/LUBE-3) 


\section{REFERENCES}

[1] Growcock, F.B., Frederick, T.P, Reece, A.R., Green, G.W., Ruffin, M.D.: Novel Lubricants for Water Based Drilling Fluids, SPE Paper, 50710, SPE International Symposium on Oilfield Chemistry, (1998)

[2] Quigley, M.S., Dzlalowski, A.K., Zamora, M., A Full-Scale Wellbore Friction Simulator, SPE Paper, 19958, IADC/SPE Drilling Conference held in Houston, Texas, (1990)

[3] R. J. Tailleur, Lubricating Properties of Drilling Fluids (E.P. Muds), Universidad Nacional de Buenos Aires, Mene Grande Oil Company, Venezuela, (1963)

[4] Knox, D. and Jiang, P., Drilling Further with Water-Based Fluids-Selecting the Right Lubricant, SPE Paper, 2002, SPE Annual Technical Conference and Exhibition, (2005)

[5] Schamp, H.J., Estes, B.L., Keller, S.R., Torque Reduction Techniques in ERD wells, SPE Paper, 98969, IADC/SPE Drilling Conference held in Miami, Florida, U.S.A. (2006)

[6] Isambourg, P., E.P., Elf, Ottosen, S., Benaissa, S., Marti, J., Down-Hole Stimulation Cell for Measurement of Lubricity and Differential Pressure Sticking, SPE Paper, 52816, IADC/SPE Drilling Conference held in Amsterdam, Holland. (1999)

[7] Reid, P.I., Meeten, H.G., Way, P.W., Clark, Peter, Chambers, B.D., Gilmour, Alan, Sanders, M.W., Differential-Sticking Mechanisms and a Simple Wellsite Test for Monitoring and Optimizing Drilling Mud Properties, SPE Paper, 64114, SPE Drill \& Completion, Vol. 15, No. 2, (2000)

[8] Kercheville, J.D., Hinds, A.A., Clements, W.R., Comparison of Environmentally Acceptable Materials With Diesel Oil for Drilling Mud Lubricity and Spotting Fluid 
Formulations, SPE Paper, 14797, IADC/SPE Drilling Conference held in Dallas, (1986)

[9] Sifferman R., Thomas, Mujis M., Herman, Fanta F., George, Felker Frederick C., Erhan M., Selim, Starch-Lubricant Compositions For Improved Lubricity and Fluid Loss in Water-Based Drilling Muds, SPE Paper, 80213, SPE International Symposium on Oilfield Chemistry held in Houston, Texas, U.S.A, (2003).

[10] Tyldsley, D., Lubricant SSP - The Proven Lubricant to Reduce High Downhole Torque, SPE Paper, 8159, SPE Offshore Europe Conference, Aberdeen, Scotland (1979)

[11] Dzlalowski, Andrew, Hale, Arthur, Mahajan, Satish, Lubricity and Wear of Shale: Effects of Drilling Fluids and Mechanical Parameters, SPE Paper, 25730, IADC/SPE Drilling Conference held in Amsterdam, Holland. (1993)

[12] Skalle, P., Backe, K.R., ve Lyomov, S.K.: Microbeads as Lubricant in Drilling Muds Using a Modified Lubricity Tester, SPE Paper, 56562, SPE Annual Technical Conference and Exhibition, (1999).

[13] Quigley, M.C., Advanced Technology for Laboratory Measurement of Drilling Fluid Friction Coefficient, SPE Paper, 19537, 64th Annual Technical Conference and Exhibition of SPE held in San Antonio, TX, (1989)

[14] Maidla, E.E., Wojtanowicz, A.K., Laboratory Study of Borehole Friction Factor With a Dynamic-Filtration Apparatus, SPE Paper, 18558, SPE Annual Technical Conference and Exhibition, (1990).

[15] Foxenberg, W.E., Ali, S.A., Long, T.P., Vian, J., Field Experience Shows That New Lubricant Reduces Friction and Improves Formation Compatibility and Environmental Impact, SPE Paper, 112483, SPE International Symposium and Exhibition on Formation Damage held in Louisiana, U.S.A. (2008)

[16] Argillier, J-F., Audibert, A., Janssen, M., Demoulin, A., Development of a New Non-Polluting Ester Based Lubricant for Water Based Muds: Laboratory and Field 
Tests Results, SPE Paper, 36862, SPE European Petroleum Conference held in Milan, Italy. (1996)

[17] Precisa, Precisa Balance Instruction Manual, 2006

[18] Sterling, Sterling Multimixer Model \#983 Instruction Manual, 2003

[19] OFITE Instruments, OFITE Ageing Cell Instruction Manual, 2009

[20] FANN Instruments, FANN Roller Oven Model 705S Instruction Manual, 2009

[21] OFITE Instruments, OFITE Lubricity Tester Instruction Manual, 2009

[22] M-I Drilling Fluids, Drilling Fluids Engineering Manual, Copyright 1998

[23] OAKTON Instruments, Waterproof pHTestr 2 Instruction Manual, 2008

[24] BAKER HUGHES, Baker Fluid Facts, Copyright 1998

[25] BAROID, BAROID Fluids Handbook, 1997

[26] OFITE Instruments, OFITE Metal Mud Balance Instruction Manual, 2009

[27] FANN Instruments, FANN Model 35 Viscometer Instruction Manual, 2008

[28] OFITE Instruments, OFITE API Filter Press Instruction Manual, 2009 


\section{APPENDIX A}

\section{TEST RESULTS OF LUBRICANTS}

All the test results that we have concluded, adding LUBE-1, LUBE-2, LUBE-3, HEAVY OIL, LIGHT OIL and DIESEL into the water-based lignosulfonate drilling fluid with different compositions, are demonstrated in APPENDIX A. 
Table A.1: Test Results of LUBE-1 Added Alone to the Water-Based Lignosulfonate Mud.

\begin{tabular}{|c|c|c|c|c|}
\hline Sample & 1 & 2 & 3 & 4 \\
\hline Water, cc & 350 & 350 & 350 & 350 \\
\hline Bentonite, ppb & 20 & 20 & 20 & 20 \\
\hline $\mathrm{CMC}, \mathrm{ppb}$ & 2 & 2 & 2 & 2 \\
\hline $\begin{array}{l}\text { Chrome-Free Lignosulfonate (CFL), } \\
\text { ppb }\end{array}$ & 3 & 3 & 3 & 3 \\
\hline $\mathrm{NaOH}, \mathrm{ppb}$ & 0.75 & 0.75 & 0.75 & 0.75 \\
\hline OCMA, ppb & 30 & 30 & 30 & 30 \\
\hline Barite, ppb & 10 & 10 & 10 & 10 \\
\hline LUBE-1 & $0.0 \%$ & $1.0 \%$ & $2.0 \%$ & $3.0 \%$ \\
\hline Viscosity temp., $\mathrm{F}$ & 120 & 120 & 120 & 120 \\
\hline Viscosity, 600 reading & 36 & 48 & 42 & 44 \\
\hline Viscosity, 300 reading & 22 & 30 & 28 & 30 \\
\hline PV & 14 & 18 & 14 & 14 \\
\hline YP & 8 & 12 & 14 & 16 \\
\hline Gel Strengths, $10 \mathrm{sec} . / 10 \mathrm{~min}$. & $3 / 4$ & $3 / 5$ & $2 / 4$ & $3 / 4$ \\
\hline API Fluid Loss, cc & 5.5 & 5.1 & 5.0 & 4.8 \\
\hline $\mathrm{Ca}$ & 60 & 40 & 40 & 40 \\
\hline $\mathrm{Cl}$ & 2,300 & 2,200 & 2,400 & 2,500 \\
\hline $\mathrm{pH}$ & 9.00 & 8.80 & 8.70 & 9.20 \\
\hline Ageing Time, hr & 16 & 16 & 16 & 16 \\
\hline Ageing Temp., F & 150 & 150 & 150 & 150 \\
\hline Foam Forming, Half-Life (minutes) & No & No & No & No \\
\hline Cheesing/Greasing & No & No & No & No \\
\hline Lubricity Tester Test Time (min) & 5 & 5 & 5 & 5 \\
\hline Lubricity Tester RPM & 60 & 60 & 60 & 60 \\
\hline Lubricity Tester Given Torque (in-lb) & 150 & 150 & 150 & 150 \\
\hline Torque (measured) @ 5 min & 26 & 12 & 9.6 & 9.7 \\
\hline Calibration Torque Reading & 35.5 & 34.4 & 34.4 & 34.4 \\
\hline Correction Factor & 0.958 & 0.988 & 0.988 & 0.988 \\
\hline Mud Lubricity Coefficient & 0.249 & 0.119 & 0.095 & 0.096 \\
\hline
\end{tabular}


Table A.2: Test Results of LUBE-2 Added Alone to the Water-Based Lignosulfonate Mud.

\begin{tabular}{|l|c|c|c|c|}
\hline Sample & $\mathbf{1}$ & $\mathbf{2}$ & $\mathbf{3}$ & $\mathbf{4}$ \\
\hline Water, cc & 350 & 350 & 350 & 350 \\
\hline Bentonite, ppb & 20 & 20 & 20 & 20 \\
\hline CMC, ppb & 2 & 2 & 2 & 2 \\
\hline Chrome-Free Lignosulfonate (CFL), ppb & 3 & 3 & 3 & 3 \\
\hline NaOH, ppb & 0.75 & 0.75 & 0.75 & 0.75 \\
\hline OCMA, ppb & 30 & 30 & 30 & 30 \\
\hline Barite, ppb & 10 & 10 & 10 & 10 \\
\hline LUBE-2 & $0.0 \%$ & $1.0 \%$ & $2.0 \%$ & $3.0 \%$ \\
\hline Viscosity temp., F & 120 & 120 & 120 & 120 \\
\hline Viscosity, 600 reading & 36 & 36 & 39 & 44 \\
\hline Viscosity, 300 reading & 22 & 21 & 22 & 26 \\
\hline PV & 14 & 15 & 17 & 18 \\
\hline YP & 8 & 6 & 5 & 8 \\
\hline Gel Strengths, 10 sec. / 10 min. & $3 / 4$ & $3 / 6$ & $3 / 4$ & $3 / 5$ \\
\hline API Fluid Loss, cc & 5.5 & 5.3 & 5.4 & 5.4 \\
\hline Ca & 60 & 60 & 40 & 60 \\
\hline Cl & 2,300 & 2,700 & 2,600 & 2,400 \\
\hline pH & 9.00 & 9.00 & 8.80 & 8.80 \\
\hline Ageing Time, hr & 16 & 16 & 16 & 16 \\
\hline Ageing Temp., F & 150 & 150 & 150 & 150 \\
\hline Foam Forming, Half-Life (minutes) & No & 13 & 15 & 16 \\
\hline Cheesing/Greasing & No & No & No & No \\
\hline Lubricity Tester Test Time (min) & 5 & 5 & 5 & 5 \\
\hline Lubricity Tester RPM & 60 & 60 & 60 & 60 \\
\hline Lubricity Tester Given Torque (in-lb) & 150 & 150 & 150 & 150 \\
\hline Torque (measured) @ 5 min & 26 & 21.7 & 17.5 & 14.5 \\
\hline Calibration Torque Reading & 35.5 & 35.5 & 35.5 & 35.5 \\
\hline Correction Factor & 0.958 & 0.958 & 0.958 & 0.958 \\
\hline Mud Lubricity Coefficient & 0.249 & 0.208 & 0.168 & 0.139 \\
\hline
\end{tabular}


Table A.3: Test Results of LUBE-3 Added Alone to the Water-Based Lignosulfonate Mud.

\begin{tabular}{|l|c|c|c|c|}
\hline Sample & $\mathbf{1}$ & $\mathbf{2}$ & $\mathbf{3}$ & $\mathbf{4}$ \\
\hline Water, cc & 350 & 350 & 350 & 350 \\
\hline Bentonite, ppb & 20 & 20 & 20 & 20 \\
\hline CMC, ppb & 2 & 2 & 2 & 2 \\
\hline Chrome-Free Lignosulfonate (CFL), ppb & 3 & 3 & 3 & 3 \\
\hline NaOH, ppb & 0.75 & 0.75 & 0.75 & 0.75 \\
\hline OCMA, ppb & 30 & 30 & 30 & 30 \\
\hline Barite, ppb & 10 & 10 & 10 & 10 \\
\hline LUBE-3 & $0.0 \%$ & $1.0 \%$ & $2.0 \%$ & $3.0 \%$ \\
\hline Viscosity temp., F & 120 & 120 & 120 & 120 \\
\hline Viscosity, 600 reading & 36 & 25 & 31 & 36 \\
\hline Viscosity, 300 reading & 22 & 15 & 19 & 21 \\
\hline PV & 14 & 10 & 12 & 15 \\
\hline YP & 8 & 5 & 7 & 6 \\
\hline Gel Strengths, 10 sec. / 10 min. & $3 / 4$ & $2 / 5$ & $2 / 6$ & $3 / 5$ \\
\hline API Fluid Loss, cc & 5.5 & 5.7 & 5.5 & 5.6 \\
\hline Ca & 60 & 80 & 72 & 68 \\
\hline Cl & 2,300 & 2,500 & 2,400 & 2,300 \\
\hline pH & 9.00 & 9.00 & 9.10 & 9.00 \\
\hline Ageing Time, hr & 16 & 16 & 16 & 16 \\
\hline Ageing Temp., F & 150 & 150 & 150 & 150 \\
\hline Foam Forming, Half-Life (minutes) & No & No & No & No \\
\hline Cheesing/Greasing & No & No & No & No \\
\hline Lubricity Tester Test Time (min) & 5 & 5 & 5 & 5 \\
\hline Lubricity Tester RPM & 60 & 60 & 60 & 60 \\
\hline Lubricity Tester Given Torque (in-lb) & 150 & 150 & 150 & 150 \\
\hline Torque (measured) @ 5 min & 26 & 21.9 & 20.1 & 19.2 \\
\hline Calibration Torque Reading & 35.5 & 33 & 33 & 33 \\
\hline Correction Factor & 0.958 & 1.030 & 1.030 & 1.030 \\
\hline Mud Lubricity Coefficient & 0.249 & 0.226 & 0.207 & 0.198 \\
\hline
\end{tabular}


Table A.4: Test Results of LIGHT OIL Added Alone to the Water-Based Lignosulfonate Mud.

\begin{tabular}{|l|c|c|c|c|c|}
\hline Sample & $\mathbf{1}$ & $\mathbf{2}$ & $\mathbf{3}$ & $\mathbf{4}$ & $\mathbf{5}$ \\
\hline Water, cc & 350 & 350 & 350 & 350 & 350 \\
\hline Bentonite, ppb & 20 & 20 & 20 & 20 & 20 \\
\hline CMC, ppb & 2 & 2 & 2 & 2 & 2 \\
\hline $\begin{array}{l}\text { Chrome-Free Lignosulfonate (CFL), } \\
\text { ppb }\end{array}$ & 3 & 3 & 3 & 3 & 3 \\
\hline NaOH, ppb & 0.75 & 0.75 & 0.75 & 0.75 & 0.75 \\
\hline OCMA, ppb & 30 & 30 & 30 & 30 & 30 \\
\hline Barite, ppb & 10 & 10 & 10 & 10 & 10 \\
\hline LIGHT OIL & $0.0 \%$ & $1.0 \%$ & $2.0 \%$ & $3.0 \%$ & $5.0 \%$ \\
\hline Viscosity temp., F & 120 & 120 & 120 & 120 & 120 \\
\hline Viscosity, 600 reading & 36 & 36 & 46 & 48 & 44 \\
\hline Viscosity, 300 reading & 22 & 23 & 28 & 30 & 29 \\
\hline PV & 14 & 13 & 18 & 18 & 15 \\
\hline YP & 8 & 10 & 10 & 12 & 14 \\
\hline Gel Strengths, 10 sec. / 10 min. & $3 / 4$ & $2 / 6$ & $3 / 6$ & $3 / 5$ & $3 / 5$ \\
\hline API Fluid Loss, cc & 5.5 & 5.2 & 4.9 & 4.6 & 4.0 \\
\hline Ca & 60 & 60 & 80 & 60 & 52 \\
\hline Cl & 2,300 & 2,100 & 2,200 & 2,000 & 2,200 \\
\hline pH & 9.00 & 9.00 & 9.10 & 9.30 & 8.90 \\
\hline Ageing Time, hr & 16 & 16 & 16 & 16 & 16 \\
\hline Ageing Temp., F & 150 & 150 & 150 & 150 & 150 \\
\hline Foam Forming, Half-Life (minutes) & No & No & No & No & No \\
\hline Cheesing/Greasing & No & No & No & No & Yes \\
\hline Lubricity Tester Test Time (min) & 5 & 5 & 5 & 5 & 5 \\
\hline Lubricity Tester RPM & 60 & 60 & 60 & 60 & 60 \\
\hline Lubricity Tester Given Torque (in-lb) & 150 & 150 & 150 & 150 & 150 \\
\hline Torque (measured) @ 5 min & 26 & 24 & 23 & 22.3 & 23.9 \\
\hline Calibration Torque Reading & 35.5 & 35.5 & 35.5 & 35.5 & 35.5 \\
\hline Correction Factor & 0.958 & 0.958 & 0.958 & 0.958 & 0.958 \\
\hline Mud Lubricity Coefficient & 0.249 & 0.230 & 0.220 & 0.214 & 0.229 \\
\hline
\end{tabular}


Table A.5: Test Results of HEAVY OIL Added Alone to the Water-Based Lignosulfonate Mud.

\begin{tabular}{|l|c|c|c|c|}
\hline Sample & $\mathbf{1}$ & $\mathbf{2}$ & $\mathbf{3}$ & $\mathbf{4}$ \\
\hline Water, cc & 350 & 350 & 350 & 350 \\
\hline Bentonite, ppb & 20 & 20 & 20 & 20 \\
\hline CMC, ppb & 2 & 2 & 2 & 2 \\
\hline Chrome-Free Lignosulfonate (CFL), ppb & 3 & 3 & 3 & 3 \\
\hline NaOH, ppb & 0.75 & 0.75 & 0.75 & 0.75 \\
\hline OCMA, ppb & 30 & 30 & 30 & 30 \\
\hline Barite, ppb & 10 & 10 & 10 & 10 \\
\hline HEAVY OIL & $0.0 \%$ & $1.0 \%$ & $2.0 \%$ & $3.0 \%$ \\
\hline Viscosity temp., F & 120 & 120 & 120 & 120 \\
\hline Viscosity, 600 reading & 36 & 57 & 63 & 70 \\
\hline Viscosity, 300 reading & 22 & 37 & 40 & 45 \\
\hline PV & 14 & 20 & 23 & 25 \\
\hline YP & 8 & 17 & 17 & 20 \\
\hline Gel Strengths, 10 sec. / 10 min. & $3 / 4$ & $4 / 6$ & $4 / 7$ & $4 / 5$ \\
\hline API Fluid Loss, cc & 5.5 & 5.3 & 5.0 & 4.6 \\
\hline Ca & 60 & 60 & 40 & 52 \\
\hline Cl & 2,300 & 2,300 & 1,900 & 2.100 \\
\hline pH & 9.00 & 9.0 & 9.20 & 8.90 \\
\hline Ageing Time, hr & 16 & 16 & 16 & 16 \\
\hline Ageing Temp., F & 150 & 150 & 150 & 150 \\
\hline Foam Forming, Half-Life (minutes) & No & No & No & No \\
\hline Cheesing/Greasing & No & Yes & Yes & Yes \\
\hline Lubricity Tester Test Time (min) & 5 & 5 & 5 & 5 \\
\hline Lubricity Tester RPM & 60 & 60 & 60 & 60 \\
\hline Lubricity Tester Given Torque (in-lb) & 150 & 150 & 150 & 150 \\
\hline Torque (measured) @ 5 min & 26 & 25 & 24.1 & 24.2 \\
\hline Calibration Torque Reading & 35.5 & 35.5 & 35.5 & 35.5 \\
\hline Correction Factor & 0.958 & 0.958 & 0.958 & 0.958 \\
\hline Mud Lubricity Coefficient & 0.249 & 0.239 & 0.231 & 0.232 \\
\hline & & & & \\
\hline
\end{tabular}


Table A.6: Test Results of DIESEL Added Alone to the Water-Based Lignosulfonate Mud.

\begin{tabular}{|l|c|c|c|c|}
\hline Sample & $\mathbf{1}$ & $\mathbf{2}$ & $\mathbf{3}$ & $\mathbf{4}$ \\
\hline Water, cc & 350 & 350 & 350 & 350 \\
\hline Bentonite, ppb & 20 & 20 & 20 & 20 \\
\hline CMC, ppb & 2 & 2 & 2 & 2 \\
\hline Chrome-Free Lignosulfonate (CFL), ppb & 3 & 3 & 3 & 3 \\
\hline NaOH, ppb & 0.75 & 0.75 & 0.75 & 0.75 \\
\hline OCMA, ppb & 30 & 30 & 30 & 30 \\
\hline Barite, ppb & 10 & 10 & 10 & 10 \\
\hline DIESEL & $0.0 \%$ & $1.0 \%$ & $2.0 \%$ & $3.0 \%$ \\
\hline Viscosity temp., F & 120 & 120 & 120 & 120 \\
\hline Viscosity, 600 reading & 36 & 53 & 55 & 64 \\
\hline Viscosity, 300 reading & 22 & 34 & 37 & 41 \\
\hline PV & 14 & 19 & 18 & 23 \\
\hline YP & 8 & 15 & 19 & 18 \\
\hline Gel Strengths, 10 sec. / 10 min. & $3 / 4$ & $3 / 6$ & $4 / 6$ & $4 / 7$ \\
\hline API Fluid Loss, cc & 5.5 & 5.4 & 5.6 & 5.6 \\
\hline Ca & 60 & 36 & 60 & 48 \\
\hline Cl & 2,300 & 2,000 & 2,200 & 2,000 \\
\hline pH & 9.00 & 9.10 & 9.20 & 9.0 \\
\hline Ageing Time, hr & 16 & 16 & 16 & 16 \\
\hline Ageing Temp., F & 150 & 150 & 150 & 150 \\
\hline Foam Forming, Half-Life (minutes) & No & No & No & No \\
\hline Cheesing/Greasing & No & Yes & Yes & Yes \\
\hline Lubricity Tester Test Time (min) & 5 & 5 & 5 & 5 \\
\hline Lubricity Tester RPM & 60 & 60 & 60 & 60 \\
\hline Lubricity Tester Given Torque (in-lb) & 150 & 150 & 150 & 150 \\
\hline Torque (measured) @ 5 min & 26 & 25.5 & 25 & 26.4 \\
\hline Calibration Torque Reading & 35.5 & 35.5 & 35.5 & 35.5 \\
\hline Correction Factor & 0.958 & 0.958 & 0.958 & 0.958 \\
\hline Mud Lubricity Coefficient & 0.249 & 0.244 & 0.239 & 0.253 \\
\hline
\end{tabular}


Table A.7: Test Results of LUBE-1 Mixed with LIGHT OIL and Added to the WaterBased Lignosulfonate Mud.

\begin{tabular}{|c|c|c|c|c|c|c|}
\hline Sample & 1 & 2 & 3 & 4 & 5 & 6 \\
\hline Water, cc & 350 & 350 & 350 & 350 & 350 & 350 \\
\hline Bentonite, $\mathrm{ppb}$ & 20 & 20 & 20 & 20 & 20 & 20 \\
\hline CMC, ppb & 2 & 2 & 2 & 2 & 2 & 2 \\
\hline $\begin{array}{l}\text { Chrome-Free Lignosulfonate } \\
\text { (CFL), ppb }\end{array}$ & 3 & 3 & 3 & 3 & 3 & 3 \\
\hline $\mathrm{NaOH}, \mathrm{ppb}$ & 0.75 & 0.75 & 0.75 & 0.75 & 0.75 & 0.75 \\
\hline OCMA, ppb & 30 & 30 & 30 & 30 & 30 & 30 \\
\hline Barite, $\mathrm{ppb}$ & 10 & 10 & 10 & 10 & 10 & 10 \\
\hline LUBE-1 & $1.0 \%$ & $1.0 \%$ & $1.0 \%$ & $2.0 \%$ & $2.0 \%$ & $2.0 \%$ \\
\hline LIGHT OIL & $1.0 \%$ & $2.0 \%$ & $3.0 \%$ & $1.0 \%$ & $2.0 \%$ & $3.0 \%$ \\
\hline Viscosity temp., F & 120 & 120 & 120 & 120 & 120 & 120 \\
\hline Viscosity, 600 reading & 53 & 54 & 63 & 50 & 55 & 58 \\
\hline Viscosity, 300 reading & 34 & 35 & 40 & 36 & 37 & 39 \\
\hline PV & 19 & 19 & 23 & 14 & 18 & 19 \\
\hline YP & 15 & 16 & 17 & 22 & 19 & 20 \\
\hline Gel Strengths, $10 \mathrm{sec} . / 10 \mathrm{~min}$. & $3 / 5$ & $3 / 6$ & $2 / 4$ & $3 / 5$ & $2 / 3$ & $3 / 4$ \\
\hline API Fluid Loss, cc & 4.8 & 4.5 & 4.3 & 4.4 & 4.3 & 4.2 \\
\hline $\mathrm{Ca}$ & 40 & 48 & 40 & 52 & 52 & 40 \\
\hline $\mathrm{Cl}$ & 2000 & 2,000 & 1,800 & 2,000 & 2,000 & 1,800 \\
\hline $\mathrm{pH}$ & 9.00 & 8.80 & 9.20 & 8.8 & 8.8 & 8.90 \\
\hline Ageing Time, hr & 16 & 16 & 16 & 16 & 16 & 16 \\
\hline Ageing Temp., F & 150 & 150 & 150 & 150 & 150 & 150 \\
\hline Foam Forming, Half-Life (minutes) & No & No & No & No & No & No \\
\hline Cheesing/Greasing & No & No & No & No & No & No \\
\hline Lubricity Tester Test Time (min) & 5 & 5 & 5 & 5 & 5 & 5 \\
\hline Lubricity Tester RPM & 60 & 60 & 60 & 60 & 60 & 60 \\
\hline $\begin{array}{l}\text { Lubricity Tester Given Torque (in- } \\
\text { lb) }\end{array}$ & 150 & 150 & 150 & 150 & 150 & 150 \\
\hline Torque (measured) @ 5 min & 11 & 10 & 5.9 & 9 & 8.3 & 8 \\
\hline Calibration Torque Reading & 32.5 & 34.5 & 35 & 34.5 & 35 & 33.2 \\
\hline Correction Factor & 1.046 & 0.986 & 0.971 & 0.986 & 0.971 & 1.024 \\
\hline Mud Lubricity Coefficient & 0.115 & 0.099 & 0.057 & 0.089 & 0.081 & 0.082 \\
\hline
\end{tabular}


Table A.8: Test Results of LUBE-2 Mixed with LIGHT OIL and Added to the WaterBased Lignosulfonate Mud.

\begin{tabular}{|l|c|c|c|c|c|c|}
\hline Sample & $\mathbf{1}$ & $\mathbf{2}$ & $\mathbf{3}$ & $\mathbf{4}$ & $\mathbf{5}$ & $\mathbf{6}$ \\
\hline Water, cc & 350 & 350 & 350 & 350 & 350 & 350 \\
\hline Bentonite, ppb & 20 & 20 & 20 & 20 & 20 & 20 \\
\hline CMC, ppb & 2 & 2 & 2 & 2 & 2 & 2 \\
\hline $\begin{array}{l}\text { Chrome-Free Lignosulfonate (CFL), } \\
\text { ppb }\end{array}$ & 3 & 3 & 3 & 3 & 3 & 3 \\
\hline NaOH, ppb & 0.75 & 0.75 & 0.75 & 0.75 & 0.75 & 0.75 \\
\hline OCMA, ppb & 30 & 30 & 30 & 30 & 30 & 30 \\
\hline Barite, ppb & 10 & 10 & 10 & 10 & 10 & 10 \\
\hline LUBE-2 & $1.0 \%$ & $1.0 \%$ & $1.0 \%$ & $2.0 \%$ & $2.0 \%$ & $2.0 \%$ \\
\hline LIGHT OIL & $1.0 \%$ & $2.0 \%$ & $3.0 \%$ & $1.0 \%$ & $2.0 \%$ & $3.0 \%$ \\
\hline Viscosity temp., F & 120 & 120 & 120 & 120 & 120 & 120 \\
\hline Viscosity, 600 reading & 43 & 46 & 44 & 36 & 48 & 48 \\
\hline Viscosity, 300 reading & 25 & 28 & 29 & 23 & 30 & 31 \\
\hline PV & 18 & 18 & 15 & 13 & 18 & 17 \\
\hline YP & 7 & 10 & 14 & 10 & 12 & 14 \\
\hline Gel Strengths, 10 sec. / 10 min. & $2 / 4$ & $2 / 5$ & $3 / 4$ & $3 / 4$ & $3 / 5$ & $3 / 5$ \\
\hline API Fluid Loss, cc & 5.0 & 4.9 & 4.8 & 4.8 & 4.7 & 4.5 \\
\hline Ca & 40 & 60 & 36 & 44 & 40 & 36 \\
\hline Cl & 1,800 & 1,900 & 1,800 & 1,800 & 1,800 & 1,700 \\
\hline pH & 9.30 & 8.80 & 9.0 & 9.20 & 9.30 & 9.00 \\
\hline Ageing Time, hr & 16 & 16 & 16 & 16 & 16 & 16 \\
\hline Ageing Temp., F & 150 & 150 & 150 & 150 & 150 & 150 \\
\hline Foam Forming, Half-Life (minutes) & 15 & 14 & 16 & 18 & 17 & 19 \\
\hline Cheesing/Greasing & No & No & No & No & No & No \\
\hline Lubricity Tester Test Time (min) & 5 & 5 & 5 & 5 & 5 & 5 \\
\hline Lubricity Tester RPM & 60 & 60 & 60 & 60 & 60 & 60 \\
\hline Lubricity Tester Given Torque (in-lb) & 150 & 150 & 150 & 150 & 150 & 150 \\
\hline Torque (measured) @ 5 min & 19.5 & 7.7 & 5 & 8.1 & 6.6 & 3.4 \\
\hline Calibration Torque Reading & 32.5 & 35 & 33.2 & 34.5 & 35 & 32.5 \\
\hline Correction Factor & 1.046 & 0.971 & 1.024 & 0.986 & 0.971 & 1.046 \\
\hline Mud Lubricity Coefficient & 0.204 & 0.075 & 0.051 & 0.080 & 0.064 & 0.036 \\
\hline & & & & & \\
\hline
\end{tabular}


Table A.9: Test Results of LUBE-3 Mixed with LIGHT OIL and Added to the WaterBased Lignosulfonate Mud.

\begin{tabular}{|c|c|c|c|c|c|c|}
\hline Sample & 1 & 2 & 3 & 4 & 5 & 6 \\
\hline Water, cc & 350 & 350 & 350 & 350 & 350 & 350 \\
\hline Bentonite, $\mathrm{ppb}$ & 20 & 20 & 20 & 20 & 20 & 20 \\
\hline CMC, ppb & 2 & 2 & 2 & 2 & 2 & 2 \\
\hline $\begin{array}{l}\text { Chrome-Free Lignosulfonate } \\
\text { (CFL), ppb }\end{array}$ & 3 & 3 & 3 & 3 & 3 & 3 \\
\hline $\mathrm{NaOH}, \mathrm{ppb}$ & 0.75 & 0.75 & 0.75 & 0.75 & 0.75 & 0.75 \\
\hline OCMA, ppb & 30 & 30 & 30 & 30 & 30 & 30 \\
\hline Barite, ppb & 10 & 10 & 10 & 10 & 10 & 10 \\
\hline LUBE-3 & $1.0 \%$ & $1.0 \%$ & $1.0 \%$ & $2.0 \%$ & $2.0 \%$ & $2.0 \%$ \\
\hline LIGHT OIL & $1.0 \%$ & $2.0 \%$ & $3.0 \%$ & $1.0 \%$ & $2.0 \%$ & $3.0 \%$ \\
\hline Viscosity temp., $\mathrm{F}$ & 120 & 120 & 120 & 120 & 120 & 120 \\
\hline Viscosity, 600 reading & 32 & 30 & 32 & 31 & 32 & 31 \\
\hline Viscosity, 300 reading & 19 & 17 & 19 & 19 & 19 & 18 \\
\hline PV & 13 & 13 & 13 & 12 & 13 & 13 \\
\hline YP & 6 & 4 & 6 & 7 & 6 & 5 \\
\hline Gel Strengths, $10 \mathrm{sec} . / 10 \mathrm{~min}$. & $3 / 4$ & $3 / 5$ & $3 / 4$ & $3 / 4$ & $3 / 5$ & $2 / 5$ \\
\hline API Fluid Loss, cc & 5.2 & 4.9 & 5.0 & 5.0 & 5.0 & 4.9 \\
\hline $\mathrm{Ca}$ & 40 & 48 & 36 & 44 & 36 & 40 \\
\hline $\mathrm{Cl}$ & 1,900 & 2,000 & 1,700 & 1,800 & 1,900 & 1,800 \\
\hline $\mathrm{pH}$ & 9.30 & 8.80 & 9.20 & 9.1 & 9.30 & 9.00 \\
\hline Ageing Time, hr & 16 & 16 & 16 & 16 & 16 & 16 \\
\hline Ageing Temp., $\mathrm{F}$ & 150 & 150 & 150 & 150 & 150 & 150 \\
\hline $\begin{array}{l}\text { Foam Forming, Half-Life } \\
\text { (minutes) }\end{array}$ & No & No & No & No & No & No \\
\hline Cheesing/Greasing & No & No & No & No & No & No \\
\hline Lubricity Tester Test Time (min) & 5 & 5 & 5 & 5 & 5 & 5 \\
\hline Lubricity Tester RPM & 60 & 60 & 60 & 60 & 60 & 60 \\
\hline $\begin{array}{l}\text { Lubricity Tester Given Torque } \\
\text { (in-lb) }\end{array}$ & 150 & 150 & 150 & 150 & 150 & 150 \\
\hline Torque (measured) @ 5 min & 20.6 & 9.3 & 5.5 & 18.5 & 10.1 & 11 \\
\hline Calibration Torque Reading & 32.5 & 35 & 33.2 & 34.5 & 35 & 32.5 \\
\hline Correction Factor & 1.046 & 0.971 & 1.024 & 0.986 & 0.971 & 1.046 \\
\hline Mud Lubricity Coefficient & 0.216 & 0.090 & 0.056 & 0.182 & 0.098 & 0.115 \\
\hline
\end{tabular}


Table A.10: Test Results of LUBE-1/LUBE-2/LUBE-3 Mixed with HEAVY OIL and Added to the Water-Based Lignosulfonate Mud.

\begin{tabular}{|c|c|c|c|c|c|c|}
\hline Sample & 1 & 2 & 3 & 4 & 5 & 6 \\
\hline Water, cc & 350 & 350 & 350 & 350 & 350 & 350 \\
\hline Bentonite, ppb & 20 & 20 & 20 & 20 & 20 & 20 \\
\hline CMC, ppb & 2 & 2 & 2 & 2 & 2 & 2 \\
\hline $\begin{array}{l}\text { Chrome-Free Lignosulfonate } \\
(\mathrm{CFL}), \mathrm{ppb}\end{array}$ & 3 & 3 & 3 & 3 & 3 & 3 \\
\hline $\mathrm{NaOH}, \mathrm{ppb}$ & 0.75 & 0.75 & 0.75 & 0.75 & 0.75 & 0.75 \\
\hline OCMA, ppb & 30 & 30 & 30 & 30 & 30 & 30 \\
\hline Barite, ppb & 10 & 10 & 10 & 10 & 10 & 10 \\
\hline LUBE-1 & $1.0 \%$ & $1.0 \%$ & & & & \\
\hline LUBE-2 & & & $1.0 \%$ & $1.0 \%$ & & \\
\hline LUBE-3 & & & & & $1.0 \%$ & $1.0 \%$ \\
\hline HEAVY OIL & & $2.0 \%$ & & $2.0 \%$ & & $2.0 \%$ \\
\hline Viscosity temp., $\mathrm{F}$ & 120 & 120 & 120 & 120 & 120 & 120 \\
\hline Viscosity, 600 reading & 48 & 49 & 36 & 54 & 25 & 49 \\
\hline Viscosity, 300 reading & 30 & 31 & 21 & 34 & 15 & 32 \\
\hline $\mathrm{PV}$ & 18 & 18 & 15 & 20 & 10 & 17 \\
\hline YP & 12 & 13 & 6 & 14 & 5 & 15 \\
\hline Gel Strengths, $10 \mathrm{sec} . / 10 \mathrm{~min}$. & $2 / 5$ & $3 / 5$ & $3 / 5$ & $3 / 6$ & $2 / 3$ & $2 / 4$ \\
\hline API Fluid Loss, cc & 5.1 & 5.0 & 5.3 & 5.0 & 5.7 & 5.5 \\
\hline $\mathrm{Ca}$ & 40 & 44 & 60 & 52 & 80 & 40 \\
\hline $\mathrm{Cl}$ & 2,200 & 2,500 & 2,700 & 1,800 & 2,500 & 2,000 \\
\hline $\mathrm{pH}$ & 8.80 & 9.10 & 9.00 & 9.30 & 9.00 & 9.30 \\
\hline Ageing Time, hr & 16 & 16 & 16 & 16 & 16 & 16 \\
\hline Ageing Temp., F & 150 & 150 & 150 & 150 & 150 & 150 \\
\hline $\begin{array}{l}\text { Foam Forming, Half-Life } \\
\text { (minutes) }\end{array}$ & No & No & 13 & 14 & No & No \\
\hline Cheesing/Greasing & No & Yes & No & Yes & No & Yes \\
\hline Lubricity Tester Test Time (min) & 5 & 5 & 5 & 5 & 5 & 5 \\
\hline Lubricity Tester RPM & 60 & 60 & 60 & 60 & 60 & 60 \\
\hline $\begin{array}{l}\text { Lubricity Tester Given Torque } \\
\text { (in-lb) }\end{array}$ & 150 & 150 & 150 & 150 & 150 & 150 \\
\hline Torque (measured) @ 5 min & 12 & 12.9 & 21.7 & 20 & 21.9 & 21.4 \\
\hline Calibration Torque Reading & 34.4 & 32.5 & 35.5 & 32.5 & 33 & 32.5 \\
\hline Correction Factor & 0.988 & 1.046 & 0.958 & 1.046 & 1.030 & 1.046 \\
\hline Mud Lubricity Coefficient & 0.119 & 0.135 & 0.208 & 0.209 & 0.226 & 0.224 \\
\hline
\end{tabular}


Table A.11: Test Results of LUBE-1/LUBE-2/LUBE-3 Mixed with DIESEL and Added to the Water-Based Lignosulfonate Mud.

\begin{tabular}{|l|c|c|c|c|c|c|}
\hline Sample & $\mathbf{1}$ & $\mathbf{2}$ & $\mathbf{3}$ & $\mathbf{4}$ & $\mathbf{5}$ & $\mathbf{6}$ \\
\hline Water, cc & 350 & 350 & 350 & 350 & 350 & 350 \\
\hline Bentonite, ppb & 20 & 20 & 20 & 20 & 20 & 20 \\
\hline CMC, ppb & 2 & 2 & 2 & 2 & 2 & 2 \\
\hline $\begin{array}{l}\text { Chrome-Free Lignosulfonate } \\
\text { (CFL), ppb }\end{array}$ & 3 & 3 & 3 & 3 & 3 & 3 \\
\hline NaOH, ppb & 0.75 & 0.75 & 0.75 & 0.75 & 0.75 & 0.75 \\
\hline OCMA, ppb & 30 & 30 & 30 & 30 & 30 & 30 \\
\hline Barite, ppb & 10 & 10 & 10 & 10 & 10 & 10 \\
\hline LUBE-1 & $1.0 \%$ & $1.0 \%$ & & & & \\
\hline LUBE-2 & & & $1.0 \%$ & $1.0 \%$ & & \\
\hline LUBE-3 & & & & & $1.0 \%$ & $1.0 \%$ \\
\hline DIESEL & 120 & $2.0 \%$ & & $2.0 \%$ & & $2.0 \%$ \\
\hline Viscosity temp., F & 48 & 52 & 120 & 120 & 120 & 120 \\
\hline Viscosity, 600 reading & 30 & 35 & 21 & 50 & 25 & 50 \\
\hline Viscosity, 300 reading & 18 & 17 & 15 & 17 & 15 & 32 \\
\hline PV & 12 & 18 & 6 & 16 & 5 & 18 \\
\hline YP & $2 / 4$ & $3 / 4$ & $3 / 4$ & $3 / 5$ & $2 / 4$ & $2 / 4$ \\
\hline Gel Strengths, 10 sec. / 10 min. & 5.1 & 5.2 & 5.3 & 5.6 & 5.7 & 5.4 \\
\hline API Fluid Loss, cc & 40 & 60 & 60 & 36 & 80 & 72 \\
\hline Ca & 2,200 & 1,800 & 2,700 & 2,200 & 2,500 & 1,900 \\
\hline Cl & 8.80 & 9.00 & 9.00 & 8.90 & 9.00 & 9.10 \\
\hline pH & 16 & 16 & 16 & 16 & 16 & 16 \\
\hline Ageing Time, hr & 150 & 150 & 150 & 150 & 150 & 150 \\
\hline Ageing Temp., F & No & No & 13 & 13 & No & No \\
\hline $\begin{array}{l}\text { Foam Forming, Half-Life } \\
\text { (minutes) }\end{array}$ & No & Yes & No & Yes & No & Yes \\
\hline Cheesing/Greasing & 5 & 5 & 5 & 5 & 5 & 5 \\
\hline Lubricity Tester Test Time (min) & 60 & 60 & 60 & 60 & 60 & 60 \\
\hline Lubricity Tester RPM & 150 & 150 & 150 & 150 & 150 & 150 \\
\hline $\begin{array}{l}\text { Lubricity Tester Given Torque } \\
\text { (in-lb) }\end{array}$ & 12 & 16 & 21.7 & 22 & 21.9 & 24 \\
\hline Torque (measured) @ 5 min & 34.4 & 35.5 & 35.5 & 35.5 & 33 & 35.5 \\
\hline Calibration Torque Reading & 0.988 & 0.958 & 0.958 & 0.958 & 1.030 & 0.958 \\
\hline Correction Factor & 0.119 & 0.153 & 0.208 & 0.211 & 0.226 & 0.230 \\
\hline Mud Lubricity Coefficient & & & & & \\
\hline
\end{tabular}


Table A.12: Test Results of Influence of Calcium Ion on Mud Properties and Lubricity

\begin{tabular}{|l|c|c|c|c|}
\hline Sample & $\mathbf{1}$ & $\mathbf{2}$ & $\mathbf{3}$ & $\mathbf{4}$ \\
\hline Water, cc & 350 & 350 & 350 & 350 \\
\hline Bentonite, ppb & 20 & 20 & 20 & 20 \\
\hline CMC, ppb & 2 & 2 & 2 & 2 \\
\hline $\begin{array}{l}\text { Chrome-Free Lignosulfonate (CFL), } \\
\text { ppb }\end{array}$ & 3 & 3 & 3 & 3 \\
\hline NaOH, ppb & 0.75 & 0.75 & 0.75 & 0.75 \\
\hline Gypsum, ppb & 1 & 1 & 1 & 1 \\
\hline OCMA, ppb & 30 & 30 & 30 & 30 \\
\hline Barite, ppb & 10 & 10 & 10 & 10 \\
\hline LUBE-1 & & $2.0 \%$ & & \\
\hline LUBE-2 & & & $2.0 \%$ & \\
\hline LUBE-3 & & & & $2.0 \%$ \\
\hline LIGHT OIL & & $1.0 \%$ & $1.0 \%$ & $1.0 \%$ \\
\hline Viscosity temp., F & 120 & 120 & 120 & 120 \\
\hline Viscosity, 600 reading & 36 & 38 & 36 & 45 \\
\hline Viscosity, 300 reading & 22 & 23 & 22 & 26 \\
\hline PV & 14 & 15 & 14 & 19 \\
\hline YP & 8 & 8 & 8 & 7 \\
\hline Gel Strengths, 10 sec. / 10 min. & $2 / 5$ & $2 / 5$ & $2 / 4$ & $3 / 4$ \\
\hline API Fluid Loss, cc & 5.7 & 4.7 & 5.2 & 5.1 \\
\hline Ca & 500 & 480 & 500 & 500 \\
\hline Cl & 2,000 & 1,800 & 2,100 & 1,800 \\
\hline pH & 9.00 & 9.20 & 8.90 & 9.00 \\
\hline Ageing Time, hr & 16 & 16 & 16 & 16 \\
\hline Ageing Temp., F & 150 & 150 & 150 & 150 \\
\hline Foam Forming, Half-Life (minutes) & No & No & 15 & No \\
\hline Cheesing/Greasing & No & No & No & No \\
\hline Lubricity Tester Test Time (min) & 5 & 5 & 5 & 5 \\
\hline Lubricity Tester RPM & 60 & 60 & 60 & 60 \\
\hline Lubricity Tester Given Torque (in-lb) & 150 & 150 & 150 & 150 \\
\hline Torque (measured) @ 5 min & 19.8 & 7.5 & 7 & 16 \\
\hline Calibration Torque Reading & 32 & 32 & 32 & 32 \\
\hline Correction Factor & 1.063 & 1.063 & 1.063 & 1.063 \\
\hline Mud Lubricity Coefficient & 0.210 & 0.080 & 0.074 & 0.170 \\
\hline
\end{tabular}


Table A.13: Test Results of Influence of $\mathrm{pH}$ on Mud Properties and Lubricity

\begin{tabular}{|c|c|c|c|c|}
\hline Sample & 1 & 2 & 3 & 4 \\
\hline Water, cc & 350 & 350 & 350 & 350 \\
\hline Bentonite, ppb & 20 & 20 & 20 & 20 \\
\hline CMC, ppb & 2 & 2 & 2 & 2 \\
\hline $\begin{array}{l}\text { Chrome-Free Lignosulfonate (CFL), } \\
\text { ppb }\end{array}$ & 3 & 3 & 3 & 3 \\
\hline $\mathrm{NaOH}, \mathrm{ppb}$ & 1.5 & 1.5 & 1.5 & 1.5 \\
\hline OCMA, ppb & 30 & 30 & 30 & 30 \\
\hline Barite, ppb & 10 & 10 & 10 & 10 \\
\hline LUBE-1 & & $2.0 \%$ & & \\
\hline LUBE-2 & & & $2.0 \%$ & \\
\hline LUBE-3 & & & & $2.0 \%$ \\
\hline LIGHT OIL & & $1.0 \%$ & $1.0 \%$ & $1.0 \%$ \\
\hline Viscosity temp., F & 120 & 120 & 120 & 120 \\
\hline Viscosity, 600 reading & 39 & 53 & 43 & 41 \\
\hline Viscosity, 300 reading & 24 & 32 & 26 & 25 \\
\hline PV & 15 & 21 & 17 & 16 \\
\hline YP & 9 & 11 & 8 & 9 \\
\hline Gel Strengths, $10 \mathrm{sec} . / 10 \mathrm{~min}$. & $3 / 9$ & $4 / 12$ & $3 / 11$ & $3 / 10$ \\
\hline API Fluid Loss, cc & 5.6 & 5.3 & 5.4 & 5.7 \\
\hline $\mathrm{Ca}$ & 60 & 60 & 80 & 80 \\
\hline $\mathrm{Cl}$ & 1,700 & 1,800 & 1,700 & 1,900 \\
\hline $\mathrm{pH}$ & 11.50 & 11.30 & 11.50 & 11.40 \\
\hline Ageing Time, hr & 16 & 16 & 16 & 16 \\
\hline Ageing Temp., F & 150 & 150 & 150 & 150 \\
\hline Foam Forming, Half-Life (minutes) & No & No & 14 & No \\
\hline Cheesing/Greasing & No & No & No & No \\
\hline Lubricity Tester Test Time (min) & 5 & 5 & 5 & 5 \\
\hline Lubricity Tester RPM & 60 & 60 & 60 & 60 \\
\hline Lubricity Tester Given Torque (in-lb) & 150 & 150 & 150 & 150 \\
\hline Torque (measured) @ 5 min & 22.8 & 9.3 & 8.4 & 18 \\
\hline Calibration Torque Reading & 32.4 & 32.4 & 32.4 & 32.4 \\
\hline Correction Factor & 1.049 & 1.049 & 1.049 & 1.049 \\
\hline Mud Lubricity Coefficient & 0.239 & 0.098 & 0.088 & 0.189 \\
\hline
\end{tabular}


Table A.14: Test Results of Influence of Chloride Ion on Mud Properties and Lubricity

\begin{tabular}{|c|c|c|c|c|}
\hline Sample & 1 & 2 & 3 & 4 \\
\hline Water, cc & 350 & 350 & 350 & 350 \\
\hline Bentonite, ppb & 20 & 20 & 20 & 20 \\
\hline CMC, ppb & 2 & 2 & 2 & 2 \\
\hline $\begin{array}{l}\text { Chrome-Free Lignosulfonate (CFL), } \\
\text { ppb }\end{array}$ & 3 & 3 & 3 & 3 \\
\hline $\mathrm{NaOH}, \mathrm{ppb}$ & 0.75 & 0.75 & 0.75 & 0.75 \\
\hline $\mathrm{NaCl}, \mathrm{ppb}$ & 4 & 4 & 4 & 4 \\
\hline OCMA, ppb & 30 & 30 & 30 & 30 \\
\hline Barite, ppb & 10 & 10 & 10 & 10 \\
\hline LUBE-1 & & $2.0 \%$ & & \\
\hline LUBE-2 & & & $2.0 \%$ & \\
\hline LUBE-3 & & & & $2.0 \%$ \\
\hline LIGHT OIL & & $1.0 \%$ & $1.0 \%$ & $1.0 \%$ \\
\hline Viscosity temp., F & 120 & 120 & 120 & 120 \\
\hline Viscosity, 600 reading & 39 & 55 & 40 & 67 \\
\hline Viscosity, 300 reading & 25 & 37 & 26 & 47 \\
\hline PV & 14 & 18 & 14 & 20 \\
\hline YP & 11 & 19 & 12 & 27 \\
\hline Gel Strengths, $10 \mathrm{sec} . / 10 \mathrm{~min}$. & $4 / 16$ & $5 / 22$ & $3 / 17$ & $8 / 32$ \\
\hline API Fluid Loss, cc & 5.9 & 5.3 & 5.7 & 5.8 \\
\hline $\mathrm{Ca}$ & 40 & 48 & 40 & 52 \\
\hline $\mathrm{Cl}$ & 10,000 & 9,900 & 10,000 & 10,000 \\
\hline $\mathrm{pH}$ & 9.00 & 8.80 & 8.80 & 8.90 \\
\hline Ageing Time, hr & 16 & 16 & 16 & 16 \\
\hline Ageing Temp., F & 150 & 150 & 150 & 150 \\
\hline Foam Forming, Half-Life (minutes) & No & No & 15 & No \\
\hline Cheesing/Greasing & No & No & No & No \\
\hline Lubricity Tester Test Time (min) & 5 & 5 & 5 & 5 \\
\hline Lubricity Tester RPM & 60 & 60 & 60 & 60 \\
\hline Lubricity Tester Given Torque (in-lb) & 150 & 150 & 150 & 150 \\
\hline Torque (measured) @ 5 min & 20.2 & 14.2 & 13 & 19 \\
\hline Calibration Torque Reading & 32 & 32 & 32 & 32 \\
\hline Correction Factor & 1.063 & 1.063 & 1.063 & 1.063 \\
\hline Mud Lubricity Coefficient & 0.215 & 0.151 & 0.138 & 0.202 \\
\hline
\end{tabular}


Table A.15: Test Results of Influence of Mud We1ght without Lubricants on Mud Properties and Lubricity

\begin{tabular}{|l|c|c|c|c|c|}
\hline Sample & 1 & 2 & 3 & 4 & 5 \\
\hline Water, cc & 350 & 350 & 350 & 350 & 350 \\
\hline Bentonite, ppb & 20 & 20 & 20 & 20 & 20 \\
\hline CMC, ppb & 2 & 2 & 2 & 2 & 2 \\
\hline $\begin{array}{l}\text { Chrome-Free Lignosulfonate (CFL), } \\
\text { ppb }\end{array}$ & 3 & 3 & 3 & 3 & 3 \\
\hline NaOH, ppb & 0.75 & 0.75 & 0.75 & 0.75 & 0.75 \\
\hline OCMA, ppb & 30 & 30 & 30 & 30 & 30 \\
\hline Barite, ppb & 10 & 40 & 80 & 110 & 150 \\
\hline Viscosity temp., F & 120 & 120 & 120 & 120 & 120 \\
\hline Viscosity, 600 reading & 36 & 38 & 49 & 45 & 54 \\
\hline Viscosity, 300 reading & 22 & 23 & 29 & 26 & 32 \\
\hline PV & 14 & 15 & 20 & 19 & 22 \\
\hline YP & 8 & 8 & 9 & 7 & 10 \\
\hline Gel Strengths, 10 sec. / 10 min. & $3 / 4$ & $2 / 4$ & $3 / 5$ & $3 / 4$ & $2 / 4$ \\
\hline API Fluid Loss, cc & 5.5 & 5.6 & 5.4 & 5.0 & 5.1 \\
\hline Ca & 60 & 60 & 52 & 64.0 & 60 \\
\hline Cl & 2,300 & 1,900 & 1,800 & 1,800 & 1,800 \\
\hline pH & 9.00 & 9.1 & 8.90 & 8.7 & 9.10 \\
\hline Mud Weight, cuft & 68 & 68 & 68 & 68 & 68 \\
\hline Ageing Time, hr & 16 & 16 & 16 & 16 & 16 \\
\hline Ageing Temp., F & 150 & 150 & 150 & 150 & 150 \\
\hline Foam Forming, Half-Life (minutes) & No & No & No & No & No \\
\hline Cheesing/Greasing & No & No & No & No & No \\
\hline Lubricity Tester Test Time (min) & 5 & 5 & 5 & 5 & 5 \\
\hline Lubricity Tester RPM & 60 & 60 & 60 & 60 & 60 \\
\hline Lubricity Tester Given Torque (in-lb) & 150 & 150 & 150 & 150 & 150 \\
\hline Torque (measured) @ 5 min & 26 & 23 & 24.5 & 23.1 & 23.3 \\
\hline Calibration Torque Reading & 35.5 & 34.5 & 35.9 & 34.1 & 32 \\
\hline Correction Factor & 0.958 & 0.986 & 0.947 & 0.997 & 1.063 \\
\hline Mud Lubricity Coefficient & 0.249 & 0.227 & 0.232 & 0.230 & 0.248 \\
\hline
\end{tabular}


Table A.16: Test Results of Influence of Mud We1ght with LUBE-1 Mixed with LIGHT OIL on Mud Properties and Lubricity

\begin{tabular}{|c|c|c|c|c|c|}
\hline Sample & 1 & 2 & 3 & 4 & 5 \\
\hline Water, cc & 350 & 350 & 350 & 350 & 350 \\
\hline Bentonite, ppb & 20 & 20 & 20 & 20 & 20 \\
\hline $\mathrm{CMC}, \mathrm{ppb}$ & 2 & 2 & 2 & 2 & 2 \\
\hline $\begin{array}{l}\text { Chrome-Free Lignosulfonate (CFL), } \\
\text { ppb }\end{array}$ & 3 & 3 & 3 & 3 & 3 \\
\hline $\mathrm{NaOH}, \mathrm{ppb}$ & 0.75 & 0.75 & 0.75 & 0.75 & 0.75 \\
\hline OCMA, ppb & 30 & 30 & 30 & 30 & 30 \\
\hline Barite, $\mathrm{ppb}$ & 10 & 40 & 80 & 110 & 150 \\
\hline LUBE-1 & $2.0 \%$ & $2.0 \%$ & $2.0 \%$ & $2.0 \%$ & $2.0 \%$ \\
\hline LIGHT OIL & $1.0 \%$ & $1.0 \%$ & $1.0 \%$ & $1.0 \%$ & $1.0 \%$ \\
\hline Viscosity temp., F & 120 & 120 & 120 & 120 & 120 \\
\hline Viscosity, 600 reading & 50 & 44 & 52 & 46 & 53 \\
\hline Viscosity, 300 reading & 36 & 27 & 31 & 28 & 32 \\
\hline PV & 14 & 17 & 21 & 18 & 21 \\
\hline YP & 22 & 10 & 10 & 10 & 11 \\
\hline Gel Strengths, 10 sec. / 10 min. & $2 / 4$ & $3 / 6$ & $4 / 7$ & $3 / 5$ & $4 / 6$ \\
\hline API Fluid Loss, cc & 4.4 & 5.3 & 5.2 & 4.7 & 4.6 \\
\hline $\mathrm{Ca}$ & 52 & 60 & 80 & 40.0 & 60 \\
\hline $\mathrm{Cl}$ & 2,000 & 2,000 & 1,900 & 1,900 & 1,900 \\
\hline $\mathrm{pH}$ & 8.8 & 9 & 9.10 & 8.6 & 8.70 \\
\hline Mud Weight, cuft & 73 & 73 & 73 & 73 & 73 \\
\hline Ageing Time, hr & 16 & 16 & 16 & 16 & 16 \\
\hline Ageing Temp., F & 150 & 150 & 150 & 150 & 150 \\
\hline Foam Forming, Half-Life (minutes) & No & No & No & No & No \\
\hline Cheesing/Greasing & No & No & No & No & No \\
\hline Lubricity Tester Test Time (min) & 5 & 5 & 5 & 5 & 5 \\
\hline Lubricity Tester RPM & 60 & 60 & 60 & 60 & 60 \\
\hline Lubricity Tester Given Torque (in-lb) & 150 & 150 & 150 & 150 & 150 \\
\hline Torque (measured) @ 5 min & 9 & 8.9 & 8.9 & 5.8 & 3.6 \\
\hline Calibration Torque Reading & 34.5 & 34.5 & 35.9 & 34.1 & 32 \\
\hline Correction Factor & 0.986 & 0.986 & 0.947 & 0.997 & 1.063 \\
\hline Mud Lubricity Coefficient & 0.089 & 0.088 & 0.084 & 0.058 & 0.038 \\
\hline
\end{tabular}


Table A.17: Test Results of Influence of Mud We1ght with LUBE-2 Mixed with LIGHT OIL on Mud Properties and Lubricity

\begin{tabular}{|l|c|c|c|c|c|}
\hline Sample & $\mathbf{1}$ & $\mathbf{2}$ & $\mathbf{3}$ & $\mathbf{4}$ & $\mathbf{5}$ \\
\hline Water, cc & 350 & 350 & 350 & 350 & 350 \\
\hline Bentonite, ppb & 20 & 20 & 20 & 20 & 20 \\
\hline CMC, ppb & 2 & 2 & 2 & 2 & 2 \\
\hline $\begin{array}{l}\text { Chrome-Free Lignosulfonate (CFL), } \\
\text { ppb }\end{array}$ & 3 & 3 & 3 & 3 & 3 \\
\hline NaOH, ppb & 0.75 & 0.75 & 0.75 & 0.75 & 0.75 \\
\hline OCMA, ppb & 30 & 30 & 30 & 30 & 30 \\
\hline Barite, ppb & 10 & 40 & 80 & 110 & 150 \\
\hline LUBE-2 & $2.0 \%$ & $2.0 \%$ & $2.0 \%$ & $2.0 \%$ & $2.0 \%$ \\
\hline LIGHT OIL & $1.0 \%$ & $1.0 \%$ & $1.0 \%$ & $1.0 \%$ & $1.0 \%$ \\
\hline Viscosity temp., F & 120 & 120 & 120 & 120 & 120 \\
\hline Viscosity, 600 reading & 36 & 41 & 44 & 51 & 51 \\
\hline Viscosity, 300 reading & 23 & 25 & 26 & 31 & 31 \\
\hline PV & 13 & 16 & 18 & 20 & 20 \\
\hline YP & 10 & 9 & 8 & 11 & 11 \\
\hline Gel Strengths, 10 sec. / 10 min. & $3 / 4$ & $3 / 4$ & $2 / 3$ & $3 / 6$ & $4 / 7$ \\
\hline API Fluid Loss, cc & 4.8 & 5.3 & 5.0 & 5.0 & 4.9 \\
\hline Ca & 44 & 40 & 60 & 48.0 & 80 \\
\hline Cl & 1,800 & 2,100 & 2,000 & 2,000 & 1,800 \\
\hline pH & 9.20 & 9 & 9.00 & 8.8 & 8.90 \\
\hline Mud Weight, cuft & 78 & 78 & 78 & 78 & 78 \\
\hline Ageing Time, hr & 16 & 16 & 16 & 16 & 16 \\
\hline Ageing Temp., F & 150 & 150 & 150 & 150 & 150 \\
\hline Foam Forming, Half-Life (minutes) & 18 & 14 & 12 & 14 & 13 \\
\hline Cheesing/Greasing & No & No & No & No & No \\
\hline Lubricity Tester Test Time (min) & 5 & 5 & 5 & 5 & 5 \\
\hline Lubricity Tester RPM & 60 & 60 & 60 & 60 & 60 \\
\hline Lubricity Tester Given Torque (in-lb) & 150 & 150 & 150 & 150 & 150 \\
\hline Torque (measured) @ 5 min & 8.1 & 8 & 8 & 6.8 & 5.4 \\
\hline Calibration Torque Reading & 34.5 & 34.5 & 35.9 & 34.1 & 32 \\
\hline Correction Factor & 0.986 & 0.986 & 0.947 & 0.997 & 1.063 \\
\hline Mud Lubricity Coefficient & 0.080 & 0.079 & 0.076 & 0.068 & 0.057 \\
\hline & & & & & \\
\hline
\end{tabular}


Table A.18: Test Results of Influence of Mud We1ght with LUBE-3 Mixed with LIGHT OIL on Mud Properties and Lubricity

\begin{tabular}{|c|c|c|c|c|c|}
\hline Sample & 1 & 2 & 3 & 4 & 5 \\
\hline Water, cc & 350 & 350 & 350 & 350 & 350 \\
\hline Bentonite, $\mathrm{ppb}$ & 20 & 20 & 20 & 20 & 20 \\
\hline $\mathrm{CMC}, \mathrm{ppb}$ & 2 & 2 & 2 & 2 & 2 \\
\hline $\begin{array}{l}\text { Chrome-Free Lignosulfonate (CFL), } \\
\text { ppb }\end{array}$ & 3 & 3 & 3 & 3 & 3 \\
\hline $\mathrm{NaOH}, \mathrm{ppb}$ & 0.75 & 0.75 & 0.75 & 0.75 & 0.75 \\
\hline OCMA, ppb & 30 & 30 & 30 & 30 & 30 \\
\hline Barite, ppb & 10 & 40 & 80 & 110 & 150 \\
\hline LUBE-3 & $2.0 \%$ & $2.0 \%$ & $2.0 \%$ & $2.0 \%$ & $2.0 \%$ \\
\hline LIGHT OIL & $1.0 \%$ & $1.0 \%$ & $1.0 \%$ & $1.0 \%$ & $1.0 \%$ \\
\hline Viscosity temp., $\mathrm{F}$ & 120 & 120 & 120 & 120 & 120 \\
\hline Viscosity, 600 reading & 31 & 44 & 43 & 42 & 48 \\
\hline Viscosity, 300 reading & 19 & 26 & 25 & 24 & 29 \\
\hline PV & 12 & 18 & 18 & 18 & 19 \\
\hline YP & 7 & 8 & 7 & 6 & 10 \\
\hline Gel Strengths, $10 \mathrm{sec} . / 10 \mathrm{~min}$. & $2 / 4$ & $3 / 4$ & $2 / 4$ & $3 / 5$ & $3 / 5$ \\
\hline API Fluid Loss, cc & 5.0 & 5.2 & 4.9 & 5.1 & 5.0 \\
\hline $\mathrm{Ca}$ & 44 & 48 & 52 & 72.0 & 60 \\
\hline $\mathrm{Cl}$ & 1,800 & 1,600 & 1,800 & 1,700 & 2,200 \\
\hline $\mathrm{pH}$ & 9.1 & 8.8 & 9.20 & 8.9 & 9.00 \\
\hline Mud Weight, cuft & 86 & 86 & 86 & 86 & 86 \\
\hline Ageing Time, hr & 16 & 16 & 16 & 16 & 16 \\
\hline Ageing Temp., F & 150 & 150 & 150 & 150 & 150 \\
\hline Foam Forming, Half-Life (minutes) & No & No & No & No & No \\
\hline Cheesing/Greasing & No & No & No & No & No \\
\hline Lubricity Tester Test Time (min) & 5 & 5 & 5 & 5 & 5 \\
\hline Lubricity Tester RPM & 60 & 60 & 60 & 60 & 60 \\
\hline Lubricity Tester Given Torque (in-lb) & 150 & 150 & 150 & 150 & 150 \\
\hline Torque (measured) @ 5 min & 18.5 & 17 & 14.8 & 13.6 & 13 \\
\hline Calibration Torque Reading & 34.5 & 35.9 & 34.1 & 32 & 32 \\
\hline Correction Factor & 0.986 & 0.947 & 0.997 & 1.063 & 1.063 \\
\hline Mud Lubricity Coefficient & 0.182 & 0.161 & 0.148 & 0.145 & 0.138 \\
\hline
\end{tabular}


Table A.19: Repeatability of the Test Results of LUBE-2 Added Alone to the WaterBased Lignosulfonate Mud.

\begin{tabular}{|l|c|c|c|c|}
\hline Sample & $\mathbf{1}$ & $\mathbf{2}$ & $\mathbf{3}$ & $\mathbf{4}$ \\
\hline Water, cc & 350 & 350 & 350 & 350 \\
\hline Bentonite, ppb & 20 & 20 & 20 & 20 \\
\hline CMC, ppb & 2 & 2 & 2 & 2 \\
\hline Chrome-Free Lignosulfonate (CFL), ppb & 3 & 3 & 3 & 3 \\
\hline NaOH, ppb & 0.75 & 0.75 & 0.75 & 0.75 \\
\hline OCMA, ppb & 30 & 30 & 30 & 30 \\
\hline Barite, ppb & 10 & 10 & 10 & 10 \\
\hline LUBE-2 & $0.0 \%$ & $1.0 \%$ & $2.0 \%$ & $3.0 \%$ \\
\hline Viscosity temp., F & 120 & 120 & 120 & 120 \\
\hline Viscosity, 600 reading & 34 & 35 & 38 & 41 \\
\hline Viscosity, 300 reading & 21 & 21 & 22 & 24 \\
\hline PV & 13 & 14 & 16 & 17 \\
\hline YP & 8 & 7 & 6 & 7 \\
\hline Gel Strengths, 10 sec. / 10 min. & $3 / 4$ & $3 / 5$ & $2 / 4$ & $3 / 4$ \\
\hline API Fluid Loss, cc & 5.4 & 5.3 & 5.5 & 5.4 \\
\hline Ca & 60 & 40 & 60 & 40 \\
\hline Cl & 2,300 & 2,600 & 2,700 & 2,500 \\
\hline pH & 9.10 & 9.00 & 8.90 & 8.80 \\
\hline Ageing Time, hr & 16 & 16 & 16 & 16 \\
\hline Ageing Temp., F & 150 & 150 & 150 & 150 \\
\hline Foam Forming, Half-Life (minutes) & No & No & No & No \\
\hline Cheesing/Greasing & No & No & No & No \\
\hline Lubricity Tester Test Time (min) & 5 & 5 & 5 & 5 \\
\hline Lubricity Tester RPM & 60 & 60 & 60 & 60 \\
\hline Lubricity Tester Given Torque (in-lb) & 150 & 150 & 150 & 150 \\
\hline Torque (measured) @ 5 min & 25.8 & 21.5 & 17.8 & 14.7 \\
\hline Calibration Torque Reading & 35.5 & 35.5 & 35.5 & 35.5 \\
\hline Correction Factor & 0.958 & 0.958 & 0.958 & 0.958 \\
\hline Mud Lubricity Coefficient & 0.247 & 0.206 & 0.170 & 0.141 \\
\hline
\end{tabular}

